\title{
PARA UNA HISTORIA FISCAL DE LA MALLORCA CRISTIANA (SIGLOS XIII-XIV)
}

\author{
FOR A HISTORY OF THE TAX BURDEN IN THE CHRISTIAN MAJORCA \\ (13th-14th CENTURIES)
}

\author{
JOSÉ FRANCISCO LÓPEZ BONET \\ Universitat de les Illes Balears \\ Dept. Cultura, Consell Insular de Mallorca
}

\begin{abstract}
Resumen: Constituida como reino independiente, con el agregado posterior de Ibiza -1235-, Mallorca pasa a integrarse -1276en un conjunto con monarca propio dividido entre las islas Baleares (incluirá también Menorca incorporada en 1294) y posesiones en el sur francés, pero sigue siendo fiscalmente autónoma, a pesar de haberse visto obligado su primer monarca a jurar fidelidad al de Aragón. Es cuando el reino de Mallorca es absorbido por la corona aragonesa en 1349 que su fiscalidad pasa a ser dependiente de las necesidades de los territorios peninsulares y queda subordinada a empresas exteriores que sobrepasan su capacidad recaudatoria. La presión del monarca, envuelto en múltiples conflictos bélicos exteriores, las crisis climáticas y epidémicas, los intereses de sus grupos sociales y un elevado nivel de corrupción, constituyen un conglomerado de causas que a principios del quinientos arruina las finanzas públicas mallorquinas que quedan en situación de dependencia de los acreedores hasta entrado el siglo XIX.
\end{abstract}

Palabras clave: Impuestos; Contribuciones; Ayudas; Subsidios; Censos; Censales; Jurados.

\begin{abstract}
Constituted like an independent kingdom, with the later aggregate of Ibiza -1235-, Majorca happens to integrate 1276- in a set with own monarch divided between the Balearic islands (will also include built-in Menorca in 1294) and possessions in the French south, but it continues being fiscally independent, in spite of to have seen forced its first monarch to swear fidelity to the one of Aragon. It is when the Aragonese crown absorbs the kingdom of Majorca in 1349 that its fiscality happens to be employee of the necessities of the peninsular territories and is subordinated to outer companies that exceed their tax collecting capacity. The pressure of the monarch, surrounded in multiple outer warlike conflicts, the climatic and epidemics crises, the interests of their social groups and a high level of corruption, constitutes a conglomerate of causes that at the beginning of the five hundred ruins the Majorcan public finances, that are in situation of dependency of the creditors until entered century XIX.
\end{abstract}

Keywords: Taxes; Contributions; Aids, Subsidies; Censuses; Census; Jurors.

\section{SUMARIO}

Introducción.- 1. Los contribuyentes: 1.1. Realengo. 1.2. Habitantes de las Porciones. 1.3. Caballeros, militares, generosos y privilegiados. 1.4. Eclesiásticos1.5. Ciudadanos.- 2. La evolución del sistema físcal: 2.1 Subsidios. 2.2 Ayudas. 2.3. Proferta.- 3. la "taula" de los jurados.- 4. las cargas fiscales: A) Las cargas de la universidad y sus diferentes fuentes de ingreso. B) La transferencia impositiva.- 5. La actuación y la estrategia de los jurados. 5.1. El abastecimiento de la isla. 5.2. La política fiscal. 5.3. Los exentos. 5.4. La resistencia a las exigencias del monarca. 5.5. La captación de capitales. 5.6. Los censos. 5.7. Los "censales" 
de la universidad. 5.8. Remisiones de "censales".- 6. Planes de reforma, reestructuración y saneamiento $1359,1373,1398$.- 7. La universal consignación.- 8. El peso impositivo. 8.1 Pan y harina. 8.2 Tejidos. 8.3 Vino y vinagre. 8.4. Las carnes. 8.5. Carga general.- 9. La presión fiscal.- 10. Los momentos conflictivos.- 11. Apéndice: Las fases de la evolución secular.

\section{SIGLAS Y ABREVIATURAS UTILIZADAS}

ACA = Archivo de la Corona de Argón; ACM = Archivo Capitular de Mallorca; ADM = Archivo diocesano de Mallorca; "AEM" = "Anuario de Estudios Medievales"; ARM Archivo del Reino de Mallorca; "BSAL" = "Boletín de la Sociedad Arqueológica Luliana";

Cateura = Pablo CATeura, Política y finanzas del reino de Mallorca bajo Pedro IV de Aragón, ed. Institut d'estudis Baleàrics, Palma de Mallorca, 1982, Apéndice documental; "CHCA" = Congreso de Historia de la Corona de Aragón; Cronicón = Álvaro CAMPANER Y FUERTES, Cronicon Maioricense, ed. Establecimiento tipográfico de J. Coloma y Salas, Palma de Mallorca, 1881; Documenta = VICH I MunTANER, Documenta Regni Maioricarvm, ed. Imprenta Amengual y Muntaner, Palma de Mallorca, 1945; HGRM = Juan DAMETO, Historia General del reino de Mallorca (primera edición 1631), continuada por Vicenç MuT en 1650 en cuanto al periodo 1311-1659 (que, por su lado, tomaba la información de BINIMELIS, que había escrito en 1595). La proseguiría Jeroni ALEMANY en 1723 y todavía sería ampliada y anotada por Miguel MoRAGUES y Joaquin Maria BOVER en la edición de la Imprenta Nacional a cargo de D. Juan Guasp i Pascual, Palma de Mallorca, 1840; HUICI-CABANES = HUICICABANES, Documentos de Jaime I de Aragón, I, ed. Anubar, Zaragoza, 1982. 


\section{INTRODUCCIÓN ${ }^{1}$}

Una vez conquistada la isla con la entrada en la ciudad de las fuerzas cristianas de Jaime Primero el último día de 1229, y mientras empiezan el saqueo, la distribución del botín y el reparto de las casas y alquerías, los asaltantes que decidieron quedar en la ciudad o en las tierras obtenidas en la isla, o aquellos que se trasladarán a ellas para explotarlas, son calificados de forma tópica y breve solo como "habitantes o pobladores".

Los ocupantes de las nuevas tierras, venidos desde el área cristiana nororiental de la península, obtienen explotaciones mediante el pago anual de censos, diezmos, tascas, trecenas y otros agrers a su nuevo titular -beneficiario de la conquista en segundo, tercer o cualquier otro grado- en una porción sometida a dominio señorial o al dominio del monarca directamente, o de algún teniente en su nombre, que ostentan ciertos derechos, como el de curia, el laudemio y la "fadiga" -el derecho de retracto- y a veces están sometidos también, entre otras menores, a contribución a la defensa y a derechos sobre uso del celler o de los almacenes, al control sobre los tipos de cultivo o de explotación, a la residencia obligada y a reservas sobre la explotación de los bienes y lugares comunales. Se instalan bajo la vigilancia e intervención civil del Alcalde señorial o del Alcalde de Mallorca y bajo la jurisdicción criminal

${ }^{1}$ Este trabajo constituye una recopilación de investigaciones relativas a la historia económica del Reino de Mallorca en la Baja Edad Media, fruto de unos 20 años de trabajos dispersos en los archivos y delante de la pantalla del ordenador. La iniciación en el estudio del tema quedó plasmada en mi trabajo de 200 páginas Comunidad y Corona, que iniciaba el año 1986 la publicación de la revistạ "Estudis d'Història Econòmica”" en edición limitada reprografiada, que tuvo una difusión restringida a los especialistas universitarios. El presente trabajo consiste, de hecho, en una ampliación del primer capítulo de aquel estudio, incluyendo materiales utilizados ya anteriormente por mí, junto con otros incorporados, incluyendọ numerosas revisiones. E capítulo sobre la evolución del sistema fiscal formaba parte del mencionado trabajo y se publicó, revisado, en el homenaje al Prof. Emilio Sáez, en el no 18 del "AEM" en 1989 con el título Las cargas impositivas sobre el consumo en Mallorca $(s . X I V)$, y, en síntesis, como introducción a mi articulo del año 1991ẹn la revișta "Randa" sobre La practica fiscal en la baja Edad Media, que ha suministrado también material para una parte del capítulo 1 del presente estudio. El capítulo 11 sobre fases de la evolución secular formaba parte de las conclusiones de mi libro sobre La riqueza de la isla de Mallorça editado el año 1989 por el Consejo Insular de Mallorca, en el que ampliaba una parte de mi tesis doctoral sobre El diezmo en el reino de Mallorca y en la estructura económica de la Procuración Real (1315-1395). He hecho uso también de algunas tablas y cálculos procedentes del apartado del mismo libro sobre El patrimonio inmueble de la corona que a su vez sirvió de base al artículo Dominios seculares, patrimonio eclesiástico y rentas decimales en la Mallorca cristiana publicado en el homenaje al Dr. Santamaría Arández en el n ${ }^{\circ} 22$ de "Mayurqa" editada por la Facultad de Filosofía y letras de la universitat de las Islas Baleares en el mismo año. El capítulo 8 sobre el peso impositivo, considerablemente aumentado, constituyó mi comunicación El pes impositiu a les acaballes del segle XIV, en el "XV CHCA", Jaca, 1993. Algunos de los materiales del capítulo 10 sobre Los momentos conflictivos me orientaron a interyenir en el tema del alzamiento anti-judío de 1391, en el artículo La revuelta de 1391, efectivamente, crisis social publicado en las actas del "XIII CHCA" celebrado en Palma de Mallorca en 1987 y en mi participación Consideracions sobre l'assalt al call de ciutat de 1391, en las "Jornadas sobre judíos y conversos" del Instituto de Relaciones Culturales Baleares-Ișrael Palma,1992, editado por el Instituto de Estudis Baleàrics, Palma de Mallorca, 1999. El inicio del presente estudio, con todo ello, es el informe presentado al comité del "XVII Congreso Internacional de Ciencias Históricas" reunido en Spietz (Suiza) en septiembre de 1989, en la sección dedicada a "Los movimientos comunales" presidida por el prof. Blicke. Que el presente trabajo tenga su origen en estos estudios no significa que se trate de una simple fusion en un nuevo texto. Gran parte en él es de nụeva elaboración y recoge multitud de nuevas aportaciones y el fruto de muchas y diversas investigaciones posteriores sobre nueva documentación incorporada aunque, naturalmente, algunas certezas adquiridas trabajando el tema desde tantos ángulos y algunos descubrimientos previos tengan que aparecer de nuevo. 
única del "veguer", establecida 19 meses después de la conquista por acuerdo entre el rey y los grandes porcioneros o magnates.

No será hasta 1244 que el monarca menciona los "ciudadanos" y hasta diecinueve años después de la conquista, en 1249, no autorizarán a los mallorquines a crear un Consejo alrededor de los 6 jurados habitantes de la ciudad y reino para "gubernare vel administrare et regere totam insulam, ad fidelitatem et comodum nostrum et comune comodum universitatis"

Constituyen la parte más destacada de esta población, alejada y aligerada de la presión vigilante de sus señores, los colectivos que habían participado en la conquista, que actúan como ente jurídico unitario en representación de la aportación -y de los pobladores- de ciudades y de poblaciones catalanas, aragonesas, del Rosellón y de la Occitania -especialmente de Marsella, de Montpeller y de Narbona-, junto con las comunidades de comerciantes genoveses (convenio de junio de 1230, actualizando el de 1146) y pisanos (confirmación en 1233 de la alianza de 1113 por la cual se les daba salvoconducto y exenciones aduaneras a Mallorca), que se encontraban ya establecidas en la ciudad desde el tiempo de los musulmanes, y sus cónsules quizás tuvieron, de entrada, un papel destacado en la ordenación y regimiento de la vida económica de la ciudad.

También es importante la comunidad judía, re-establecida o permanente, que actúa preferentemente en el comercio en los momentos que entre los grupos de colonos e inmigrantes está todavía en formación una clase mercantil radicada en la ciudad y constituida, probablemente, por corresponsales o agentes de las empresas o compañías catalanas y del sur francés ${ }^{2}$, que habían obtenido inmediatamente toda clase de franquicias y exenciones en el tráfico con la isla, en iguales condiciones que sus mismos pobladores ${ }^{3}$.

Habitantes de las poblaciones catalanas, italianas y francesas; miembros de las comunidades que han participado como empresa en la conquista; pequeños sub-porcioneros de los eclesiásticos de Cataluña y de los barones que han retornado a su lugar de procedencia, dejando procuradores personales a fin de que procedan a parcelar, distribuir en arrendamiento y establecer sus bienes recientemente obtenidos; colonos, menestrales y aventureros; agentes de negocios, delegados, simples curadores u ocupantes

${ }^{2}$ El punto tercero de la Carta de Franqueza de Jaume I dada -según Álvaro SANTAMARÍA- el 1 de marzo de 1230, declaraba a los nuevos ocupantes de la isla francos de toda lleuda, peatge, portatge, mesuratge, pes i ribatges... "etc., sobre todas las mercancías que transitaran por sus nuevos territorios o por los que pudiera adquirir en el futuro. El 10 de enero de 1231 enfranqueció también a los habitantes de Barcelona, en agradecimiento por su ayuda a la conquista, de todos los derechos sobre las mercancías que traficaran con las islas. Hizo francos también a los habitantes de Tarragona -16 de marzo de 1231-; a los musulmanes habitantes de Menorca -pacto de Capdepera de 17 de junio de 1231- de "lleudes, peajes" y cualquier carga sobre mercancías, y a los judíos del Almudaina -por diez años desde el 11 de julio de 1231- de "lleudes, peatges, usatges, mesuratges" y cualquier otra exacción. La exención a los catalanes se hizo extensiva -12 de agosto de 1305- a todos los súbditos de la Corona de Aragón, al mismo tiempo que se duplicaba la carga a los de Génova de 1 a 2 dineros por libra. Los habitantes de Perpiñán y Cotlliure habían también alcanzado -26 de marzo de 131 -liberarse mediante el pago de un único canon de 5.000 libras concedidas al rey en Sanxo de Mallorca.

${ }^{3}$ Como las de 1150 a los habitantes de Lérida, en 1163 a los vecinos de Agramunt y en 1174 a los vecinos de Balaguer. Vid. José M. FONT I RIUS, Cartas de poblacion y franquicia de Cataluña, CSIC, Barcelona, 1966. 
de propiedades ajenas; desarraigados, desheredados, familias de jornaleros o de sirvientes... todos ellos constituyen una sociedad plural, que disfruta de cierta libertad para organizarse y de autonomía en la aplicación de sus franquicias y en la creación del su propio derecho consuetudinario, todo ello sobre la base de las costumbres importadas, de los derechos propios de las diversas comunidades y de los "usos" de Barcelona como derecho supletorio.

Pasados unos 20 años, la nueva sociedad de inmigrantes se ha ido organizando ella misma, ante la urgencia de constituir la vida comunal con independencia de cualquier sujeción señorial, y bajo la única vigilancia del lugarteniente real (con cometidos políticos, militares y de apelación), la intervención del alcalde correspondiente (para el registro público de las transacciones sobre los inmuebles, con mediación en los conflictos, divergencias, confluencia de intereses, asuntos mercantiles, testamentarios, de tutela y en causas por deudas, censos, faltas menores o delitos muy leves) y la autoridad del veguer que ejerce la justicia criminal, íntegramente en manos del monarca, que no tolera altas jurisdicciones penales señoriales.

La nueva comunidad tiene autonomía ejecutiva en materias económicas y fiscales, pero no legislativa, que reside en todo momento en el monarca, franquicias aparte; y eso es importante pues los Jurados tenían la misión de comprobar si cualquier disposición real que se tuviera que publicar por el gobernador o el lugarteniente podía infringir las franquicias, facultad que les confería una auditoría previa de que no dejarán de hacer uso en todo momento.

El 8 de febrero de 1257, cuando Jaume I hizo jurar las franquezas de la isla a su primogénito Pere, añadirá la cláusula que constituirá en el futuro la mayor fuerza de los jurados, cuando ordenaba que ninguna disposición suya o por emitir que fuera contra los privilegios y franquezas de la isla no tuviera ninguna validez, y obligaba a todos sus sucesores, curias, alcaldes y lugartenientes a jurarlas y respetarlas íntegras. Con eso los Jurados, que tenían que garantizar las franquezas, tenían abierto el camino a la perpetua apelación ante cualquier disposición o provisión que, según su opinión, las vulnerara y, por lo tanto, adquirían una facultad obstruccionista que constituiría, de hecho, un verdadero derecho de veto. Sancho de Mallorca, en 1322, les conferiría también facultad de hacer ordenaciones que, sin embargo, tendrían que someter a la aprobación de los oficiales superiores ${ }^{4}$

La empresa de Mallorca, de hecho, no había sido un capricho o una inspiración del monarca aragonés de 21 años, sino un proyecto largamente acariciado por sus antecesores: puesto que las costas catalanas eran la vía natural de acceso marítimo a la España cristiana por el Mediterráneo, el gran mar comercial, señoreado incluso en su parte occidental por las flotas mercantes italianas, la Corona de Aragón no podía dejar de lado el intento de establecer una réplica peninsular a aquel dominio, abriéndose al trafico y la navegación hacia el oriente y el África, imanes permanentes de la cruzada y

${ }^{4} \mathrm{ARM}$, pergaminos del rey Sanxo ${ }^{0} 15$. 
dirección preferente de la empresa cristiana y de expansión, a la vez, ideológica y mercantil.

Ramón Berenguer III y Pere I, padre del conquistador, ya habían esbozado el plan. Ramón Berenguer había llegado a desembarcar en la isla en 1115 con la ayuda de una flota de Pisa y Pere -mediante la renuncia a sus derechos personales sobre las iglesias constituidas en los territorios de repoblación y la promesa de 250 óbolos anuales que nunca se abonaronconsiguió, en noviembre de 1204, hacerse coronar por el Papa y ser nombrado "gonfalonero de la Iglesia", con la finalidad de obtener el "plácet" del pontífice y el acuerdo con los emporios italianos de Génova y Pisa, puesto que sin el consentimiento de Roma y de la flota de aquellas ciudades cualquier empresa en el Mediterráneo occidental podía convertirse en un nuevo conflicto internacional.

El reino aragonés obtuvo al fin la posesión de Mallorca en 1229, el año de la IV cruzada y del Concilio Tarraconense de Lérida en que el legado cardenalicio Jean de Abbeville incorporaba al reino de Aragón los acuerdos del IV concilio Lateranense.

Jaume I había vivido desde su infancia la amarga experiencia de las luchas nobiliarias, que alcanzará a poner en tregua por un instante gracias a la empresa de Mallorca. Su necesidad de prestigio, el afán de cruzada (que el Papa le sugiere con insistencia), la llamada del mar y la atracción de la riqueza que puede producir el tráfico marítimo (de la que toma parte también la simple apropiación), la necesidad de ocupar en empresas exteriores una nobleza de cariz feudal que se siente alejada del monarca e inmune a su autoridad, todo contribuirá a los parámetros de acuerdo con los cuales Jaume I concibió su nueva posesión:

-Enclave estratégico en las rutas comerciales marítimas, hasta cierto punto molesto y también necesario para los emporios mercantiles italianos, con la ventaja adicional de permitirle el contacto directo con el Norte de África, territorio que no interesa a los italianos, más asentados hacia el levante. El entusiasmo del monarca por esta empresa se hace patente en su crónica (cap. 105) "Dios nos ha hecho tanta gracia que nos ha dado reino dentro del mar, lo que ningún rey de España no pudo llevar a término"; es esta empresa, por lo tanto, (cap. 107) "la mejor cosa que hizo hombre alguno en cien años".

-Ciudad real en régimen comunal abierto ${ }^{5}$ con una Carta de Franqueza heredera en parte de la que había establecido Ramón Berenguer IV el 30 de noviembre de 1149 a los pobladores de Tortosa y que fue modelo de las concedidas a los repobladores de la Cataluña Nueva, más allá del Llobregat, lugar de frontera con el Islam, de riesgos pero de enormes posibilidades para desheredados y aventureros que necesitan, para poder mantenerse, determina-

${ }^{5}$ Álvaro SANTAMARÍA, Los consejos municipales de la Corona de Aragón mediado el siglo XIII. El sistema de cooptación, "Anuario de Historia del Derecho Español "A Madrid, 1981; ID. comunidades de Marsella y Montpellier en el Repartimiento de Mallorca, en XII CHCA, Montpeller, 1985. 
do grado de libertad y de autonomía ${ }^{6}$. La carta de franqueza Mallorca comparecerá sustancialmente ampliada con aspectos como: justicia gratuita y pública, inviolabilidad del domicilio, seguridad penal, consideración del adulterio como delito privado, regulación de los requerimientos y fianzas judiciales, prohibición de la tortura y de los procedimientos cruentos de prueba y libre comercio con los territorios de la corona. Pero, sobre todo, la isla se convierte en una tierra liberada de cualquier poder nobiliario, incluido el eclesiástico, en coherencia con la política de poner limitaciones al poder feudalizante que culminaría con Pere IV, y obstaculizando cualquier posibilidad de creación de una nobleza isleña.

-Como justificación ideológica, lugar adelantado contra el infiel experiencia nueva para el reino aragonés- lo que fue reconocido en numerosas bulas papales como la de Gregorio IX de 9 de abril de 1241, que autorizaba a los pobladores de Mallorca a negociar y a vender mercancías -excepto armas- a los sarracenos, y el Privilegio de Inocencio IV de 21 de marzo de 1247 que les permitía negociar con los sarracenos y venderles víveres, excepto caballos, mulas, armas, hierro y efectos navales, y también se hace patente en el intento del mismo Jaume de encabezar una cruzada en 1269, para la que se desplazó de nuevo a la isla con el fin de pedir un subsidio de 50.000 sueldos.

A lo largo del siglo XIV se desarrollará la verdadera sistemática de la estructura fiscal y de recaudación de la administración comunal isleña, cómo veremos a continuación. Aún así, nos queda por documentar el momento en que nace la posible facultad de la Universidad para cargar impuestos a iniciativa propia, que desde un principio le es denegada, tal como Jaume II recordaba el 30 de enero de 1300, cuando disponía que los jurados de la isla no podrían hacer colecta ni exacción sin licencia del rey o del lugarteniente.

La facultad de poner cargas tributarias parece partir de las Cortes de Monzón de $1363^{7}$ cuando se autorizaba a los municipios de Cataluña a cargar

\footnotetext{
"Álvaro SANTAMARÍA, La carta de Franqueza de Mallorca, en "AEM", "Homenaje a la Memoria del Profesor Emilio Sáez", CSIC, Barcelona, 1988.

${ }^{7}$ Vid.José M. FonT I RIUS, José M. La administración financiera en los municipios catalanas medievales, en "Historia de la Hacienda Española, Homenaje al prof. García de Valdeavellano," Instituto de Estudios Fiscales, Madrid, 1982; Id. Estudios sobre los derechos e instituciones locales en la Cataluña Medieval, "Col.lectànea de trabajos del prof. Font i Rius con motivo de su jubilación académica", Univ. de Barcelona, 1985. A. BOSCH, Sumario, índice o epítome de los admirables títulos de honor de Cataluña, Rosselló y Cerdaña, Perpiñán, 1628, en ed. facsímil, Barcelona-Sueca, 1974. José BINIMELIS, Historia de Mallorca y de otras islas adyacentes, tomo III de la edición de la imprenta José Tous de 1927, p. 361 informa: "El señor rey don Pedro IV dio potestad a los jurados i Grande i General Consejo de Mallorca de imponer nuevos derechos i gabelas, confirmando los que había ya impuesto la Universidad, para pagar ciertos violarios i censos, i muchos intereses que el reino padecía. Vese esto por un auto de cierto privilegio real del rey don Pedro dado en Valencia en 29 de septiembre de 1353. Todos los cuales censos i otros mas, se impusieron por tantas dádivas i auxilios que de continuo hacia este reino a sus reyes". Bernardino BAUZÀ en Por la Ivnta de la consignacion -sin fecha ni pie de imprenta, pero dedicado a Carlos II y editado después de 1702, ano de las últimas disposiciones que comenta-, que sintetizaba su información histórica a partir de los diversos datos recogidos en la HGRM, en la página 9 de la primera edición, insiste en la misma fecha: "No teniendo la Universidad de Mallorca bienes propios le fue necesario para mantenerse recurrir a la imposicion de muchos vectigales, gabelas i sisas, lo qual le fue licito .... i para ello obtuvo licencia del señor rey don Pedro mediante un privilegio cuya data es en Valencia a 29 de setiembre de 1353 . i el señor rey don Juan, con otro real privilegio de 24 de julio de 1393 le concedio que pudiesse siempre, i
} 
impuestos por su cuenta y sin la autorización real, lo que confirmó Joan Primero en 1400. Para el caso de Mallorca, la total autonomía para imponer tributos jurídicamente fundamentada, sigue sin embargo sin estar del todo asegurada puesto que todavía en $1371^{8}$. Pere IV dictaminó que no se impondrían en adelante más impuestos o "ayudas" sin su expresa autorización o la de su lugarteniente. Aún así, la acumulación de circunstancias adversas en tiempo de aquel monarca (guerra civil con las "uniones" aragonesa y Valenciana, pestes y hambres continuadas, guerras de Cerdeña y con Génova, Guerras de Castilla, continúas amenazas de invasiones por los Pirineos, permanentes conflictos internos...) traducirían sus incesantes y siempre urgentes peticiones de caudales en un alud de imposiciones creadas como fuera y aplicadas a toda prisa incluso antes de haber obtenido los asensos preceptivos, y eso habría supuesto, de hecho y en la práctica, la libertad de la Universidad para imponer, reimponer o recargar, en cada momento, al menos los impuestos más tradicionales y fáciles de obtener.

Por mucho que existan antecedentes sueltos desde principios del siglo XIV, hasta el 1392 no podemos fijar claramente la potestad autónoma de los jurados para crear imposiciones, cuando alcanzaron de Joan I enormes franquicias con el fin de garantizar la recaudación de la sanción colectiva de

quando quisiesse, imponer drechos sobre el pan, vino, carnes, azeytes i otros cualquiera vectigales en las cosas i mercadurias, i coger sus productos, venderrlos o arrendarlos como mejor pareciese a los Iurados, i Grande 1 General Consejo..." ...."La inposicion de drechos en Mallorca tuvo principio en el año 1350, que hasta entonces se avia socorrido en reyno por medio de las tallas;: aumentàronse en el año 1410, en que puso el Grande i General Consejo quatro drechos nuevos, para acabar de pagar los donativos con que havia servido a su rey...

En 1849, en el capítulo II de la Memoria sobre la Universal Consignación, el autor y antiguo secretario de la Consignación, Antoni CANALS, repite casi letra por letra las afirmaciones de BAUZÀ, cuando trata de "la creación de los arbițrios y orígen de la deuda pública del antiguo reino de Mallorca", consolidada en la Real Consignación que había sido abolida en 1835, pero que todavía pesaba, a mediados de siglo, sobre la Diputación y la Junta de Comercio de la ciudad de Palma.

Todas estas afirmaciones, que se han venido reiterando desde BINIMELIS, MUT, BAUZA y CANALS, en el sentido de que en 1353 habían autorizado a la Universidad a crear discrecionalmente imposiciones, ya que había tenido que mantenerse antes solo por vía de tallas, tienen que ser precisadas: las imposiciones que nos consta que existían anteriormente habrían quedado reducidas, según los autores citados, a recaudar cantidades por "servicios" al monarca y para necesidades defensivas extraordinarias, y los "subsidios vecinales" (por vía de talla o derrama, es decir, a proporción del patrimonio o sobre el número de habitantes) serian las que habrían mantenido las necesidades del común (obras públicas, defensa, oficiales y fiestas populares, principalmente) Sin embargo, el privilegio mencionado por aquellos autores, dado en Valencia el 29 de septiembre de 1353, de ser el que conocemos (ARM LR $17 \mathrm{f}$. 83) se refiere a unas imposiciones para una causa concreta y determinada, como es el rescate de bienes y cautivos pertenecientes a cristianos, y autorizaba a destinar a los gastos de sus armadas contra los genoveses para las guerras de Cerdeña y Córcega el impuesto de un "lou", impuesto para rescatar los bienes, mercancías y personas del leny de Berenguer Gassó y también a imponer posteriormente imposiciones y ayudas para la causa de los rescates y para enjugar las deudas y los préstamos que habían tenido que contraer algunos mercaderes por aquel motivo aclarando que, una vez satisfechos, tendrían que cesar lạs imposiciones y ayudas. En ningún momento el documento da discrecionalidad a la Universidad, a no ser que se tome solo fragmentariamente su contenido, para poder justificar cualquier tipo de imposiciọn perenne y por cualquier causa, o que existiera otro documento de la misma fecha y sobre igual tema, que no se ha localizado. Podríamos entender que BINIMELIS, MUT y los que les siguieron debían tener en su pensamiento el inicio en 1354 del proceso de acelerado endeudamiento a consecuencia de la guerra de Cerdeña, que asociaron con los privilegios obtenidos por los municipios de la Corona đe Aragón en las Cortes de Monzón de 1363, cuando hacen referencia a un documento que les parecía concordante, aunque fuera anterior en 10 años; en este caso, se trataría de una lectura apresurada que se fue transmitiendo de una pluma a otra a lo largo de los siglos.

${ }^{8} \mathrm{P}$. CATEura, doc. $\mathrm{n}^{\mathrm{o}} .160$. 
120.000 florines (90.000 libras de Mallorca) que aquél había impuesto a la isla, además de los donativos que tuvieron que hacerle a cambio de indultos y olvidos, después de las violencias anti-fiscales -con asalto a la judería incluido- que se dieron en $1391^{9}$.

\section{LOS CONTRIBUYENTES}

\subsection{Realengo}

Un procedimiento que aparece a menudo (aunque obstaculizado con frecuencia) es el de dar por supuesto el rango como algo anexo a la posesión territorial y transmitido por ella, no por la filiación o el grupo de descendencia. Si la caballería supone pertenencia a un orden y la posibilidad del ingreso en un grupo por reclutamiento, no por agnación o filiación, este proceso puede tener algún sentido, en caso de que no existiera en la isla cristiana la tradición de la nobleza de sangre.

Por eso, el 10 de mayo de 1244 el mismo conquistador Jaume I dispuso, en Játiva, que todos aquellos que poseyeran bienes dentro de la porción real de la isla (el realengo) o que los hubieran adquirido (aunque así y todo, aclararía, los poseían "por nos y por nuestro hijo el Infante Jaime") tenían que contribuir a tallas o colectas a beneficio de la ciudad, remarcando la libre disponibilidad de estas tierras que, tanto si estaban en manos de la Iglesia como de caballeros, ciudadanos u otras personas, podían ser transferidas a caballeros, siempre que se respetara el límite máximo de 500 morabatines (4.000 sueldos o 200 libras) que les había fijado antes para el posible acrecentamiento de sus patrimonios. La tributación, pues, afectaba al bien poseído al que no le correspondía ninguna exención ni siquiera en caso de que fuera a para a manos de caballeros.

Las tierras patrimoniales del monarca eran aquéllas que, por la conquista y división de Mallorca, habían ido a manos de la corona o que aquella había adquirido posteriormente, y el conquistador remarcaba que tenían un carácter de bienes de libre circulación y disposición y que su posesión no confería carácter distintivo de ningún tipo, incluso en caso de que recayeran en manos de privilegiados o que procedieran de ellas. Lo tuvo que aclarar 120 años después Pere IV (desde Barcelona el 25 de septiembre de 1366), ante la solicitud de los "militum et generosorum" de la isla que intentaban reivindicar privilegios nobiliarios, por mucho que alegaran la antigua adscripción de las tierras a nobles porcioneros de alto nivel.

Así, cuando Jaume I confirmó las franquezas en Mallorca, el 23 de julio de 1269, insistió que los honores de realengo tenían que contribuir a

\footnotetext{
${ }^{9}$ Josep Francesc LÓPEZ BONET Comunidad y corona: el precio de servir (Las cargas sobre el consumo en el siglo XIV en Mallorca), editado por "Grup d'Estudis d'Historia Económica", Palma de Mallorca, 1986, capítulo III. Id.' La revuelta de 1391, efectivamente, crisis social, Actas del "XIII CHCA, Palma de Mallorca, 1987.
} 
todas las aportaciones al común de la ciudad ("comuni vicinali o vicinatico"), y que también estaban incluidos en la obligación todos los pobladores; la disposición se reiteró en Lérida (12 de marzo de 1274), cuando el rey repetía que todos los militares y habitantes de la porción real tenían que contribuir a la reparación de murallas y la defensa de la tierra ${ }^{10}$. Alfonso el Liberal la ratificó de nuevo en Mallorca, una vez que acababa de reintegrarla a la corona aragonesa, el 5 de noviembre de 1286.

Desde este último momento, y en un intento de aprovechar la nueva situación política y la confusión que la velocidad de transmisiones de tierras había creado a lo largo del siglo, aparece el primer intento de reclamar privilegios y exenciones "personales" por parte de los caballeros que ocupaban dominios en el realengo, que intentaban vincular su condición personal a la del terreno poseído o adquirido.

Este propósito de ligar rango y posesión de los titulares de tierras en la fracción real se hizo patente cuando en 1289 Pere Torrella, caballero y procurador de los caballeros y viudas de caballeros de Mallorca, intentaba invocar privilegios para sus representados por cuanto estaban en posesión de bienes de realengo y solicitaba que se mantuviera la franqueza "antigament observada" (puesto que no estaba documentada) de no tener que contribuir a "algunas" tallas o servicios vecinales (dado que no era creíble la existencia de exención o de inmunidad fiscal total), la ampliación al doble (1000 morabatines) de la facultad de adquirir bienes de la porción del rey y que "aquests honors fossin francs i lliures", así como los demás "honors" y posesiones que les habían sido otorgadas desde que el privilegio de 1244 había sido dictado.

$\mathrm{Ni}$ pizca ingenuo, el rey pidió informes relativos a la veracidad de aquella exención de servicios y tallas vecinales que invocaban, que no cabe duda de que debieron de ser negativos porque la sentencia, encomendada al arcediano de Ribagorza y a dos jueces reales, que fue dictada en Lérida el 21 de noviembre de 1289 , denegó la ampliación de valor máximo de las adquisiciones al doble que solicitaban, mantuvo la limitación anterior, junto con la obligación de contribuir a las recaudaciones comunes y precisó, además, que estaban obligados a contribuir también en armadas para defensa de la isla

-reparación de murallas y muros

-conducción de aguas

por todo lo que tuvieran -o que otros tuvieran por ellos- dentro del realengo. Es decir -aunque no se menciona- subrayando aquellos aspectos que ya había remarcado Jaume I en sus capítulos de 1269.

En Albarracín, el 4 de octubre de 1290, les aclaraban que los caballeros que tenían honores en la porción real o realengo de Mallorca, y que se habían negado a contribuir en "atalayas y escuchas" (es decir, en la

\footnotetext{
${ }^{10}$ ARM Códice Privilegios f. 25 v y 34; Códice Rossello Nou f. 1; confirmaciones en tiempo de Pere IV, en CATEURA doc. no 32 (marzo de 1346) y 34 (marzo de 1347). Según FonT I RIUS, op. cit., p. 619, en Cataluña no estaban exentos de ninguna de las imposiciones municipales ni siquiera el monarca y sus familiares cuando pasaran por la población.
} 
contratación de vigilantes permanentes o estacionarios), de acuerdo con lo que se había dispuesto por la anterior sentencia, y puesto que se trataba de medios para la mejor defensa de la isla, tendrían que pagar también por este concepto, al igual que lo tenían que hacer en aquellos por los que estaban obligados por las posesiones que tuvieran fuera del realengo.

Diecisiete meses después (Barcelona 4 de marzo de 1292) les precisaban que los titulares de bienes de la porción del rey mantendrían la inmunidad limitada en las demás prestaciones comunales (tallas o servicios extraordinarios) solamente por aquello que tuvieran hasta los 500 morabatines de valor (es decir, por la ampliación de su patrimonio original que les habían autorizado), pero siempre con la obligación de contribuir en los casos anteriormente expresados, igual que les correspondía por sus caballerías antiguas (es decir, hereditarias fuera del realengo)

En síntesis: ninguna exención de las cargas ordinarias correspondía a los titulares de dominios en el realengo, ni siquiera la de las contribuciones o ayudas comunes.

\subsection{Habitantes de las porciones}

En un principio, el monarca concibió la isla, según el modelo de las ciudades mercantiles catalanas, como una villa real franca y privilegiada, directamente unida a la corona de Aragón y sin sujeción a cualquier poder intermedio, señorial ni eclesiástico, y así lo afirmó explícitamente en el punto 37 de la carta de Franqueza, y aunque entre 1232-1244 y 1254-56 concedería la isla en señorío al Infante de Portugal, hizo saber que lo hacía sin atentar contra las franquezas del reino, ya que el Infante actuaría hasta cierto punto sólo como un administrador y perceptor de rentas y sin facultades en fortificaciones, declaración de paz y tregua ni promulgación de privilegios.

La ciudad y su puerto son la sede única del poder político, administrativo y económico, y el acervo territorial de la isla constituye la fuente de recursos para su mantenimiento y de rentas para los porcioneros beneficiarios de la conquista, rentas que se distribuyen a sub-porcioneros, clientes, eclesiásticos o mesnaderos. Se trata de un "reino en el mar" del que la ciudad es la única expresión, como la cabeza rige y confiere identidad al cuerpo, y el territorio insular constituye solo un a modo de traspaís o de reserva alimenticia.

De entrada, pues, el flujo contributivo sólo es contemplado como afluente a la ciudad, y sus habitantes destacados tienen la consideración de "ciudadanos" (término que aparece a partir de Játiva 10 de marzo de 1244), rango inmediatamente anterior al de caballeros, que es el escalafón máximo de la pirámide estamental en la isla. Los jurados ciudadanos serán, así, los rectores de "ciudad e isla", asimilando el bien común con el de la ciudad.

Cuando Jaume I dispuso en 1244 las obligaciones contributivas de los bienes del realengo, aludía solo a las tallas y colectas en beneficio de la ciudad. Pero el 23 de julio de 1269, que precisó de manera más amplia algunos puntos de las franquezas, añadió que los habitantes de todas las 
posesiones señoriales tendrían que tributar, por todo aquello que poseyeran, a la reparación de las murallas de la ciudad y para vigilancia y armamentos realizados por mar y por tierra para la salvaguardia del reino.

En los veintitrés años transcurridos, pues, se había fijado fuera de la porción del rey una población que, por el hecho de ser dependiente de los primeros porcioneros, probablemente no había sido considerada en un principio como tributaria a los gastos comunes de defensa, pero que una vez que había alcanzado una virtual organización -y algunos de ellos probablemente rango y rentas- ahora la consideraban ya como contribuyente de derecho a determinados tributos.

La primera parte de la crónica de Jaume I o "Llibre dels Feits" (cap. 2 a 327), se supone que se redactó hacia la primera fecha (1244) ${ }^{11}$ y en ella (en el capítulo 125), el rey hace la afirmación que "e de llahora ençà. ... l'ille de Mallorques ... 1.ha nostro Senyor multiplicada, que val dos tants que no faïa en lo temps dels sarraïns".

A lo largo de estos años, no cabe duda, la "parte foránea", que adquiriría pronto presencia como entidad política y después forma jurídica, ha ido alcanzando su carácter propio y ha ido creciendo en importancia y recursos.

No hay duda, por ejemplo, que en este periodo han ido surgiendo o se han potenciado de manera expresa los núcleos de los futuros municipios como agrupaciones de pobladores de determinadas porciones o dominios, bajo la jurisdicción de los respectivos alcaldes señoriales, y que se han ido organizando en torno a la curia o la parroquia, cuya red fue reconocida, como es sabido, por la bula papal dada en Lyón el 1 de abril de 1248. Poco más allá de 50 años después de la conquista veintisiete villas tenían ya capacidad de remitir delegaciones propias, con un total de 320 síndicos, a jurar fidelidad a Alfons I el Liberal, después de su toma de la isla en $1285^{12}$.

El periodo hasta 1298, que el reino se reintegró al heredero del conquistador y su nuevo monarca por el tratado de Anagni, ha sido poco profundizado, excepto en su aspecto político-administrativo ${ }^{13}$, pero es entre 1300 y 1309 que Jaume II pudo emprender la ambiciosa constitución de un reino de características europeas, con un amplio y caro plan de dotaciones y de obras públicas, de reestructuración urbana, de creación de un sistema monetario y de ordenación del territorio insular, y son estos proyectos los que reclaman grandes cantidades de recursos y los que imponen la creación del

\footnotetext{
${ }^{11}$ Carme ARNAU, Prólogo a Llibre dels Feits, Ediciones 62, Barcelona 1988.

${ }^{12}$ Cronicón, p. 22 y notas de Guillermo TerRASSA. Vid. José Francisco LóPEZ Bonet, La diversificación fiscal, pauta del desarrollo urbano en la 'ciudad e isla' de Mallorca en "Incontro di Studi Attivita economiche e sviluppo urbano nei secoli XIV e XV". Barcelona octubre de 1995 , publicado en "Archivio Storico del Sannio", 1. Vid. también mi comunicación Los núcleos urbanos en la parte foránea en la repoblación de Mallorca (s. XIII-XIV), en "XVII CHCA", Barcelona, 2000.

${ }^{13}$ ARM Códice Sant Pere f. 137 y ss. y Códice Rosselló Vell f. 161 v. Vid. Álvaro SANTAMARÍA, La política municipal de Alfonso el Liberal en el reino de Mallorca (1285-1291) en La ciudad Hispánica durante los siglos XIII al XIV, vol. II, editado en "En la España Medieval", 7 (Madrid, 1985).
} 
sistema tributario que con el tiempo llegará a alcanzar unas características casi permanentes. El 22 de marzo de 1300 Jaume II dictó la primera disposición que conocemos relativa a la tributación de aquellos que poseyeran bienes en una parroquia, que les obligaba en obras defensivas, de vigilancia y de construcción de iglesias y en convites y diversiones que se hicieran en común para los habitantes de la parroquia ${ }^{14}$. Así lo tendrían que hacer también, por su lado, los ciudadanos en su urbe, puesto que el 22 de setiembre de 1302 el rey disponía, en relación en un tal Guillem Robert, que puesto que era ciudadano tenía que contribuir en todas las "colectas" de la ciudad aunque, como tal, estaba exento de "pes e mesuratge"15.

Como veremos después, esta última exención venía dada por las franquezas, pero parece que sólo se aplicaba a los ciudadanos; los habitantes del campo no tenían consideración de beneficiarios de privilegios ${ }^{16}$.

Cuando Jaume II se reintegró al poder -según afirmaría su hijo Sanxohabía impuesto injustas cargas a la isla, ${ }^{17}$ tal vez a modo de represalia por la pasividad de sus pobladores ante la sustracción que Pere el Gran y su hijo Alfons le habían hecho de su reino, y dado que para reintegrarse al mismo había tenido que jurar humildemente fidelidad a su sobrino Jaume II de Aragón. Sanxo decía también que su padre, a pesar de sus buenas intenciones de perdonar y de olvidar antiguos agravios ${ }^{18}$, había puesto una contribución en forma de "sisa" (es decir, a cargar sobre el precio al consumidor) por 9 años, que pareció escandalosa. En la disposición que había dictado para la ordenación y poblamiento de las villas, Jaime II había destinado el tercio de esta sisa a la constitución de aljibes y estanques en aquellas poblaciones donde no dispusieran de suficientes recursos de agua.

\footnotetext{
${ }^{14}$ ARM Códice Sindicat de Fora XIV, f. 133 y Códice Sindicat de Fora XV, f. 151. Vid. también GóMEZ DE NEGRETE, Documentos sobre la organización y atribuciones de la Junta de la Universal Consignación, imprenta de Felipe Guasp, Palma de Mallorca, 1832.

${ }^{15}$ Documenta, doc. 66.

${ }^{16}$ En la resolución de Pere IV de 31 de mayo de 1345, dirigida al Reformador y Procurador de las Rentas Reales Felip de Boil, expresamente remitido a la isla, en relación al peso y mesuratge se expone que:

-por dos letras reales (Barcelona 9.4.1344 y Perpiñán 13.12.1344) había concedido el monarca que los habitantes de la isla de Mallorca, en aplicación de las antiguas franquezas, fueran francos y. exentos de peso y mesuratge, lo que se había aplicado también a los habitantes de fuera la ciudad

-el 29.1.1345, desde Perpiñán, había mandado el mismo monarca que no se aplicara la exención a los foráneos, ya que parecía que en tiempos anteriores "no habían disfrutado" de dicha franqueza

-el 5 de febrero del mismo año, y desde la misma ciudad, había ordenado al gobernador que no impidiera al Procurador Real o a sus agentes recaudar y recibir "peso y mesuraje" de los habitantes de la ciudad y reino de Mallorca, lo que hace suponer que el gobernador había intervenido a fin de que se extendiera la franqueza a los foráneos.

-el monarca recibió acto seguido a los representantes de los mercaderes de la isla Ombert de Fullalta y Bernardó de Font, y a consecuencia de la suplica de los cuales ordenó de nuevo a gobernador y al Procurador Real que fuera aplicada la exención basada en las franquezas a los habitantes de fuera de la ciudad, tanto en peso como en mesuraje, como era acostumbrado y por las cartas anteriores había concedido, siempre reteniendo el derecho real a su propiedad. Muy a pesar de las franquezas, pues, hasta 1343 los foráneos de la isla habían abonado peso y mesuraje -al menos por espacio de una serie de años- y probablemente también los barceloneses a los que, incluso en cierto momento nos consta que les cobraban también lleuda.

${ }^{17}$ ARM Códice Privilegios, 108

${ }^{18}$ ARM Pergaminos Jaume II, n ${ }^{\circ} 10$.
} 
La práctica de contribuir se tuvo que imponer de alguna manera en la parte foránea, aún por encima de un soterrado estado de resistencia, ya que Sanxo I, en el momento de jurar y confirmar las franquezas del reino (catedral de Mallorca 4 de julio de 1311) hacía referencia a ello cuando añadió una cláusula anulando las modificaciones que había introducido su padre Jaume II el 30 de enero de 1300 y se comprometía a que en lo sucesivo no se podría imponer ninguna "questis seu collectis" sin licencia regia, a la vez que amonestaba a los jurados que las recaudaran de la mejor manera, pero con la menor molestia posible para los contribuyentes ${ }^{19}$.

Cuatro años más tarde, en 1315, los intereses económicos de las villas y de la ciudad habían entrado en confrontación.

Después de -con toda seguridad- diversas negociaciones, y aprovechando una estancia del monarca en Mallorca para firmar de forma solemne diversos estatutos y acuerdos ${ }^{20}$, Sanxo consintió en considerar la presencia de los foráneos en las decisiones de los jurados, en un pacto que ha sido ampulosamente calificado de "estatuto o carta de naturaleza" de la universitat foránea pero que, de hecho, era sólo una sentencia arbitral en la que, si atendemos a los matices, les denegaban de entrada a los hombres de las villas foráneas todas sus pretensiones económicas relativas a la carga tributaria ${ }^{21}$,

\footnotetext{
${ }^{19}$ ARM Códice Privilegios f. 108.

${ }^{20} \mathrm{El}$ más importante fue el acuerdo del "pariage" de los diezmos firmada el 13 de septiembre de 1315, que resta todavía inédito. Fue estudiado en mi tesis doctoral "El diezmo en Mallorca y en la economía de la Procuración real del reino". De hecho el pacto rey-Iglesia incluyó toda una serie de protocolos

Firmados el 13 de septiembre de 1315 :

-el pacto del "pariage" de los diezmos:

-un documento adicional relativo a diferencias en la evaluación de los patrimonios respectivos de la Iglesia de Mallorca y el rey. Según la Iglesia, el suyo excedía en 400 libras, lo que la convertía en perjudicada si se repartían los diezmos por mitad, como acababan de acordar, pues la parte que le correspondería, de ir por separado, seria mayor. Por eso el rey se comprometió a compensarla en 138,954 libras cada año, que era la diferencia entre las 200 libras y la parte que correspondía al patrimonio que había recibido la corona de la orden del Temple, y que no había sido incluida en las estimaciones previas al convenio del "pariage";

-otro pacto relativo a la jurisdicción de la Iglesia en los territorios de su porción, que le concedía -en el civil y se reservaba el rey la criminal.

Firmados el día 19 del mismo mes:

-una adición al régimen del "pariage" por la cual reconocían que lo aplicarían también a la décima parte de la moneda acuñada en Mallorca:

-la autorización perpetua a la Iglesia de Mallorca para sacar de Menorca grano procedente del diezmo, para llevarlo a Mallorca.

Firmados el día 20 del mismo mes:

-se ponía en conocimiento público que la Iglesia podía imponer sanciones dentro del territorio de su porción, en aplicación de la jurisdicción civil que le acababan de conceder.

${ }^{21} \mathrm{El}$ famoso $1 / 3$ fue pronto motivo de la expoliación del área rural por parte de la ciudad. La práctica y. el modelo de pensamiento organicista de la época imponían que los foráneos tuvieran que contribuir a las tallas por gastos comunes en el 1/3, por analogía con la obligación de la ciudad de transferirle el 1/3 de la recaudación de tallas o contribuciones, al igual que hacían en las recaudaciones para embajadas al monarca. Pero a medida que se iban creando cada vez más imposiciones sobre el consumo, mientras la ciudad comprendía menos del $50 \%$ de la población (cálculos aproximados sobre el tributo del "fogaje" nos dan que la parte de fuera reunía el 56,1\% en 1329, el $57^{\prime} 72 \%$ en 1336 , el $65 \%$ en 1343 el $59^{\prime} 6 \%$ en 1349 y el $54^{\prime} 4 \%$ en 1363), la parte foránea entraba a contribuir entre el 50 y el $65 \%$, mientras seguía recibiendo para sus necesidades solo el 33'3. En 1372 los foráneos se dieron cuenta de que les habían estado expoliando, ya que la universidad les transfería por sus gastos propios solo el 1/3 del sobrante que quedaba en la ciudad, en lugar del tercio del total recaudado y al cual había contribuido la parte foránea, por lo que calculaban -con exageración- los síndicos foráneos que les habían abonado en menos cerca de un $25 \%$ en cada recaudación. Como ejemplo numérico aportaban que, de una recaudación de
} 
por mucho que en la sentencia asomara la posibilidad de disgregar, en un futuro indefinido, la recaudación de los subsidios, ayudas y "sises" entre ambas partes (puntos XI y II).

En concreto, el rey les denegaba las peticiones relativas a:

-que no se vendiera la carne más cara en la ciudad que en las villas puesto que, de ser así, se desproveería el mercado foráneo- (punto I);

-la posibilidad de recibir $1 / 3$ de cada nueva sise, que la basaban los foráneos en el hecho de que no habían recibido la parte correspondiente de la que había impuesto Jaume II (el 31 de enero de 1300), de la que había concedido el tercio a los jurados de la ciudad para obras comunes "de toda la tierra"; según los foráneos, por lo tanto, les habrían tenido que transferir el tercio correspondiente a lo aportado por ellos para la amortización de los gastos que habían hecho en las villas por obras públicas (punto VII);

-que los consejeros de la parte foránea pudieran tener idéntica potestad que los de la ciudad en la elección de jurados y en otras ordenaciones y tratos comunes (punto XII), y también la de poder discutir directamente con los recaudadores de impuestos, mediante dos delegados por cada parroquia, (punto IX);

-que la ciudad participara en los gastos que la parte foránea hiciera en servicios al rey, como a ella la habían obligado a participar en los de la ciudad (punto III);

-que los jurados no recibieran salario (punto XIV) y que no abonaran de los fondos comunes los gastos que hacían en interés de algún particular o de sus propiedades como, por ejemplo, a fin de que algunos mercaderes pudieran recuperar los bienes perdidos en operaciones de piratería o corsarismo (punto VI).

En compensación Sanxo les concedía la formalización escrita de unas "ratios" distributivas que probablemente ya se tenían en cuenta en la práctica y que se basaban en los convenios establecidos con su antecesor, Jaume II, respecto de los subsidios vecinales y contribuciones.

En resumidas cuentas, la sentencia de Sanxo reafirmaba para el futuro cinco criterios básicos:

A) La base teórica es que las necesidades comunes tienen que ser mantenidas en conjunto:

-que siempre que se recaudaran en común subsidios y ayudas sólo se pagaran de los caudales comunes las atalayas existentes y las que se llegaran a construir (pero cargando los salarios de los "scoltes" a cada villa en particular) (punto XI), puesto que se trataba de instalaciones defensivas de interés por toda la isla;

-a los foráneos les tendrían que transferir la parte proporcional solamente de lo que hubieran aportado a los subsidios comunes de la isla para

3000 libras, de la que había resultado un sobrante de 2000 libras, la ciudad les transfería solo un tercio de esta última cifra (668,7516 libras) en lugar de las 1000 que era el tercio del tota recaudado. (Vid. CATEURA, Política y finanzas, op. cit. cap. IV p. 227) Aparte de eso, la ciudad había llegado a deber grandes sumas a los foráneos, tanto al colectivo como a diversos particulares, por concepto de préstamos efectuados al organismo. 
la reforma de vías públicas, caminos, puentes, fuentes, aljibes y demás reparaciones (punto IV), y sólo en el caso de que la ciudad recibiera cantidades por conceptos parecidos o para sus negocios propios.

B) Las necesidades particulares de la ciudad y de cada villa en particular tienen que ser soportadas por cada uno por separado, pero en el caso de que tuviesen que repartir alguna recaudación conjunta entre las dos partes (ciudad y parte foránea) para necesidades independientes la proporción sería de 2 a 1 (como era lo acostumbrado en las embajadas al monarca, aunque la sentencia no lo menciona). En ningún momento se dice que la misma proporción se tuviera que aplicar en las aportaciones a los gastos comunes de toda la isla (como por ejemplo para defensa), aunque la práctica lo hubiera impuesto ya desde antiguo, pero se aplicó por analogía. Por eso los foráneos no dejaron de apreciar muy pronto que no había correspondencia entre su peso demográfico y lo que recibirían para sus necesidades de las recaudaciones hechas en común por toda la isla si, por ejemplo, la parte foránea llegaba a estar más poblada en conjunto que la ciudad -como de hecho lo estuvo casi siempre desde el primer tercio del siglo- que sólo recibirían un tercio de lo recaudado. Este error de concepto provocó procesos y reclamaciones sin descanso por espacio de más de 150 años.

C) La autoridad y el poder decisivo reside sin ninguna duda en los jurados, sometidos a la supervisión del lugarteniente: la sentencia aclaraba que los foráneos no podían hacer ordenaciones que tocaran el bien común ni ir contra los estatutos emanados por los jurados y aprobados por el lugarteniente -con lo que seguían atados de pies y manos-, ni se podían entrometer en las sentencias por causas criminales, pero sí podrían intervenir como lo habían acostumbrado hasta el presente

D) La parte foránea tiene que ser escuchada y tiene que participar en las decisiones conjuntas, y por eso tendrá una participación política de obligada audiencia en los diversos organismos y comisiones de control, aunque sin facultades decisorias, sólo consultivas. En consecuencia les concedía:

-una cierta presencia en cierto tipo de resoluciones que les afectaran directamente: diez próceres foráneos, elegidos entre el llano y la montaña, con gastos pagados, o seis si la resolución se prolongaba más de un día o se trataba de asuntos singularmente arduos;

-si se trataba de conceder dones o subsidios al monarca, los representantes foráneos serían dos por cada parroquia, en calidad de jurados y consejeros; si el caso no se podía resolver en un día, quedarían en la ciudad ocho de aquellos para seguir tratando con los jurados, todos ellos a elegir anualmente, previa notificación a los jurados (punto VIII);

-la presencia de cuatro interventores en la declaración del estado de cuentas de los jurados, al fin de cada año (punto $\mathrm{V}$ ) y el preceptivo conocimiento y autorización de los representantes de la parte foránea para disponer de los fondos comunes (aunque los jurados podían disponer, por su cuenta y sin conocimiento ni consenso de los foráneos, de hasta 50 libras para dones 
y servicios de poca monta, cada uno de ellos por valor inferior a 5 libras (punto X);

-su participación en paridad para crear síndicos o procuradores con el fin de tratar asuntos comunes (punto XIII) y en las embajadas al rey (punto $\mathrm{XV)}$ también para asuntos comunes.

E) Para posibilitar la viabilidad de esta participación en los asuntos del común, los reconocía y autorizaba:

-la percepción de dietas por las estancias en ciudad para tratar negocios públicos, mientras se recaudaran en común las "sises", ayudas y subsidios (punto II);

-la posibilidad de ser juzgados los foráneos en el lugar donde se había hecho el contrato, el crimen o el delito, y en las causas por censos, agrarios, laudemios y otros derechos útiles (14.7.1322);

-la exención de contribuir en gastos por servicios al rey en el caso de que los jurados de la ciudad no les hubieran convocado debidamente (punto III) $(5.4 .1317)$.

De manera paralela, después de 1315 se refuerza definitivamente la conciencia distintiva entre los habitantes de la ciudad y los representantes de la "parte foránea" que muestran ya una fuerte personalidad y una digna belicosidad que se fundamenta en su auto-conciencia civil, una vez que han sido reconocidos -en una ascensión probablemente no muy deseada- a la categoría de contribuyentes homologados al mismo nivel que las clases populares urbanas -privilegiados aparte- hasta llegar al momento clave de 1322, en que se dictó la famosa y perdurable sentencia del Abad de Arlés en relación al conflicto tributario que habían planteado los titulares de bienes en las villas que tenían residencia en la ciudad, de que hablaremos enseguida.

El 13 de enero de 1332 tomó posesión Jaume III, a los 17 años, y juró las franquezas y los privilegios de la isla. Dieciséis días después el Abad de Arlés dictó la sentencia que sentaba jurisprudencia para el futuro y que será invocada en Mallorca aún en el siglo XIX.

El litigio había sido originado por diversos ciudadanos que tenían bienes en la parroquia de Montuiri, a quienes pretendían hacerles contribuir en los gastos de cierre del cementerio de la villa. El conflicto había surgido cuando se quiso averiguar quienes eran los obligados a tributar en los subsidios de cada parroquia: ¿debían sentirse obligados los que, poseyendo bienes o posesiones en las villas foráneas, residían de manera permanente $o$ la mayor parte del tiempo en la ciudad? iy los ciudadanos de derecho que residían largas temporadas en sus fincas del campo? ¿qué significado había que dar a la expresión "todos los que tengan bienes en una parroquia" contenida en la disposición de Jaume II del 22 de marzo de 1300? ¿y si tenían bienes en diversas parroquias, o en alguna parroquia y en la ciudad al mismo tiempo? ¿y los eclesiásticos, caballeros y privilegiados, había que considerarles incluidos?

Una vez debatido el caso, el Abad sentenció que, a pesar de haber alegado aquellos ciudadanos con bienes en Montuiri que cotizaban ya en la ciudad y que estaban inmunes desde la conquista de la isla de manos paganas 
-aunque no lo estaban en gastos de fortificación y defensa, atalayas, escuchas y cuerpo de la Iglesia, que era considerada como fortaleza-, tenían que contribuir también por las posesiones que tuvieran en la villa, tanto por los demás conceptos en los que no estaban exentos como para caminos, puentes, calzadas y acueductos, en tanto que las obras que se hicieran redundaran en utilidad de sus respectivas posesiones ${ }^{22}$.

Cuando Pere IV se posesionó definitivamente de la isla para la corona aragonesa y después de apresurarse a declarar (Mallorca 31 de mayo de 1343) que nadie estaba exento de gastos comunes, en aplicación de un nuevo concepto de sumisión civil, concedió (Valencia 10 de febrero de 1358), por medio de su delegado el gobernador Gilabert de Centelles, entre otros capítulos:

-que las universidades foráneas, mediante sus propios síndicos, recaudaran y gastaran la cuota de las colectas o ayudas vecinales que correspondiera a cada una, al igual que lo hacía la ciudad para ella misma, sin que debieran darse mutuamente cuenta "quod, ultra dampnosum, inutile est"; -que la ciudad tuviera que contribuir a las obras de la muralla de Alcudia, que se consideraba de utilidad para toda la isla; -que la ciudad restituyera a las universidades foráneas los préstamos que les debía, más los perjuicios causados por la demora; -que los recaudadores de las ayudas no trataran más duramente a los deudores de las villas foráneas que a los de la ciudad; -que se obligara a tributar a los clérigos y los judíos que hubieran comprado posesiones en las villas foráneas en los gastos de las parroquias correspondientes.

Quince años después, el 10 de febrero de 1368, el mismo monarca recordó que los pobladores de las porciones de los barones, militares y prelados "non contribuant in comunitatibus civitatis contra immunitates eis concessas", refiriéndose, probablemente, a la disgregación de las tributaciones entre la ciudad y las villas; los habitantes de las porciones señoriales o eclesiásticas tenían que cotizar en su lugar propio y no para la ciudad como paradigma del reino, como había estipulado al inicio al rey Jaume I.

Muy poco falta para que el monarca reconociera como "universidad" el cuerpo representativo de los habitantes de la parte foránea (Barcelona 18 de diciembre de 1373) y que les diese el privilegio de que se pudieran reunir y tener Consejo y remitir por su parte delegados al monarca y les asignara un rango jurídico distinto al de la ciudad como sede del dominio político, puesto que constituían ya -añade- Colegio y Universidad, de acuerdo con la sentencia del rey Sanxo.

Será un nuevo carácter de civilidad que no hace la distinción con criterios urbanos entre la ciudad y las villas, antes bien entre los ciudadanos

${ }^{22}$ Vid. GÓMEZ DE NEGRETE, op. cit, doc. no ${ }^{2}$ 2. También ARM AH 3458 f. 94 y Códices "Jurisdicciones e Stils" f. 107 y "Sindicato Foráneo" f. 161. 
y los plebeyos (4 de diciembre de 1368) ${ }^{23}$, cuestión más de rango que de domiciliación.

\subsection{Caballeros, militares, generosos $\mathbf{y}$ privilegiados}

Después de la caída del reino privativo, solamente se hablará de caballeros, militares (o con privilegio militar) o generosos (privilegiados en razón de descendencia) Desde Barcelona (3 de agosto de 1251) el rey hacía incluso la declaración expresa de los cinco estamentos que constituían la sociedad de la isla y que debían ser representados en condiciones paritarias en el Consejo General puesto que, como el documento afirma, había llegado a congregar a una mayoría de los mercaderes:

-militares, generosos y poseedores de privilegio militar

-ciudadanos

-mercaderes

-menestrales

-foráneos

Es significativo que cuando el 7 de julio de 1249 Jaume I había establecido desde Valencia la constitución de los 6 jurados que debían administrar la isla había dispuesto, en una breve cláusula añadida al final, que uno de ellos tenía que ser "miles", como representante de la jerarquía superior de la estructura social de la isla, y eso hizo que en la práctica se llegara a imponer la distribución normal de los 6 jurados en un caballero, dos ciudadanos, dos mercaderes y un menestral.

"Militares, ciudadanos y pobladores de la ciudad y todo el reino de Mallorca" son los beneficiarios de la sintética confirmación de las franquezas que hizo el conquistador en Valencia el 2 de agosto de 1256, al mismo tiempo que remitía su hijo Jaume a la isla a fin de que fuera jurado como heredero del reino.

Hay, pues, dos términos extraños a la estructura de la sociedad de la isla que tienen apariciones ocasionales y accidentales en diversos momentos: -uno de ellos es el de "nobilium" que, excepto como tratamiento de los gobernadores y de algún familiar real, sólo aparece utilizado muy excepcionalmente como, por ejemplo, por Jaume I desde Valencia el 6 de julio de 1249 ("nobilis uel miles, uel secularis, clericus uel religiosus") y el 23 del mismo mes ("nobilibus uel capitalibus ... homines nobilium siue capitalium ... nobiles capitales ") junto con los "ordinum clericorum et militum", y por la cancillería de Pere IV en los primeros años de su dominio sobre la isla (Tarragona 1 de marzo de 1345; Valencia 29 de marzo de 1347) -el otro término, inducido por la costumbre de los redactores de la Cancillería aragonesa, es el de "hombre de paraje" o de "paraticum", aludido en Burriana el 14 de junio de 1363 (Joan Brondo, delegado de "cauallers e homes de paratge" de la isla) y en Barcelona (25 de enero de 1368 "militum

\footnotetext{
${ }^{23}$ ARM Códice Sant Jordi f. 78.
} 
de paratico"): se trata de una denominación frecuente en los territorios peninsulares de la corona aragonesa, que designaba a hombres de la pequeña nobleza de los caballeros, donceles o quizás residente en sus posesiones campesinas, que constituían la nobleza rural, pero es una calificación muy poco conocida en las islas.

La aristocracia de la isla tiene un carácter esencial de guarnición militar, retribuida a través de las rentas obtenidas de la posesión de porciones del territorio que sus titulares tienen cedidas en explotación a terceros, y no existe, como rasgo distintivo, la relación de descendencia directa de los grandes nobles participantes en la conquista. Los caballeros son titulares de dominios cedidos por los grandes beneficiarios que financiaron la expedición de conquista con su aportación en hombres o dinero, o que las ocupan en nombre suyo o que las han adquirido de cualquier otra manera.

Su dominio territorial se limitaba a los derechos de curia, de registro y de la percepción de rentas sobre la explotación y transmisión del terreno, muchas veces dado en enfiteusis. Dentro de estas posesiones hay que distinguir las cedidas en porción que correspondió al monarca en el reparto -el realengo, de que ya hemos hablado- de aquéllas que se distribuyeron o transfirieron dentro de las otras cuatro porciones a principios de 1231, cuando sus altos titulares (excepto el Conde de Ampurias, que había muerto a causa de la peste que se declaró en la ciudad de Mallorca justo cuando acababan de entrar en ella) estaban ya en Barcelona, donde en julio del mismo año firmaron el pacto por el que sólo el veguer real podría entender en casos judiciales civiles o criminales ${ }^{24}$.

Se trata de unos poseedores de titularidad del dominio que lo tienen siempre bajo el eminente del monarca, lejos del feudalismo político o clásico por el hecho de que no hay siervos con sujeción a la tierra, cesión de soberanía mediante la facultad judicial o dispositiva, clientelas privadas de carácter militar ni poder jurisdiccional autónomo: la única jurisdicción que ejercían era la registral y menor, a través del "batle" de la porción, sujeto a apelación delante del alcalde (real) de Mallorca, y la disciplinaria y de orden público (corrección y penalización de faltas y represión de delitos menores), puesto que las jurisdicciones penal y criminal residían en manos del rey, mediante el veguer (real) de Mallorca.

Los titulares de dominio no pueden dictar leyes ni disposiciones penales ni imponer otras cargas que las que tienen transferidas (censos, agrarios -tascas y diezmos- y derechos de curia) y no tienen jurisdicción sobre vías públicas, puentes, cursos de agua ni fortificaciones. Tampoco, excepto

\footnotetext{
${ }^{24}$ Los cuatro porcioneros distintos del rey eran:

-Nuño Sanz. Sus bienes pasaron a la corona a partir de 1242

-el obispo de Barcelona, con jurisdicción civil compartida con el monarca desde 1315 .

-el heredero del conde Huc d'Empúries, que había muerto en Mallorca en una peste declarada inmediatamente después de la entrada en la ciudad. Se autorizó la transferencia de sus territorios a los hermanos Pere y Francesc Font en 1318, pero el rey se retenía el dominio directo, los laudemios, las faticas y los foriscapios;

-Gastó de Bearn, heredero de los Montcada: sus bienes los empeñó la corona en 1310, aunque después se pactó una indemnización.
} 
la fidelidad debida, tienen obligaciones feudales (homenaje, auxilio, consejo, hueste y cabalgada...) con respecto al monarca, ni las pueden imponer. Sus obligaciones de participación en cargos públicos lo son respecto a la comunidad (en el seno del Consejo de los jurados y como oficiales públicos -veguer, mostassaf, lugarteniente, etc... -) y sus obligaciones militares se limitan al mantenimiento perpetuo de uno o más caballos armados (o fracción) para la defensa de la isla (no del monarca) y de revista o de intervención militar a requerimiento del gobernador, como delegado del monarca.

La intención de poner límites a la creación de una aristocracia territorial que pudiera convertirse en poderosa y autónoma, reduciéndola al simple carácter de terratenientes privilegiados comprometidos en la defensa de la isla, se evidenciaba desde un principio, cuando según el punto 2 de las Franquezas todas las posesiones tenidas por los pobladores eran declaradas francas y libres -y el monarca se compromete a confirmarlo así en cada carta de posesión- y también libremente transmisibles -aun en el caso de que no se respetara el derecho a la herencia de los posibles hijos- menos a caballeros y clérigos que restaban, por lo tanto, sin posibilidad de adquirir y acumular bienes inmuebles.

Pocos años después (asedio de Játiva, 10 de mayo de 1244) cuando confirmó las franquezas y añadió la expresa mención del reino de Valencia acabado de conquistar (junto con Colliure, Denia y Barcelona) a la exención en lezdas y peajes que tenían los mallorquines dentro de todos sus dominios, el rey autorizó a los "milites" pobladores de la isla a comprar posesiones y rentas de manos de cualquiera (militares, clérigos, ciudadanos u otras personas) sólo hasta un máximo de 500 morabatines (200 libras), y les permitió también la venta hasta la cantidad mencionada en alodio propio franco y libre, siempre a reserva del dominio, el derecho y la fidelidad debidos al monarca.

La confirmación posterior de las Franquezas de 1269, que hemos mencionado, cuando el conquistador hizo su cuarto viaje a la isla con la finalidad de obtener la ayuda económica para una proyectada cruzada a Tierra Santa que no acabaría de llevar a cabo (tenía, entonces, 61 años y murió siete años más tarde), contenía cuatro capítulos sobre la tributación de aquellos que poseían tierras y de los pobladores sometidos a sus dominios:

-los milites y cualquier otra persona que comprara heredades o posesiones o que adquiriera de hombres del servicio real en la ciudad o la isla, o de otras personas, cualquier derecho sobre el realengo, tendrían que abonar, ellos mismos y los pobladores de dichas posesiones o heredades, la parte correspondiente de todo comuni uicinali o uicinatico de la ciudad, al igual que los ciuis y habitantes de la ciudad lo tenían que hacer por las casas, heredades o posesiones que tuvieran en la ciudad o su término (excepto el "censu sive agrario" debido al dominio) y por todos los bienes muebles, excepto por las casas, heredades o posesiones que tuvieran por nobles / capitales o por iglesias I órdenes religiosas fuera de la ciudad y que no fueran de realengo, que estaban de por sí exentas. 
-los hombres nobles / capitales y las órdenes de clérigos / militares tendrían que contribuir por sus bienes a la construcción y reparación de murallas y de muros de la ciudad, de atalayas y de armamento de mar y de tierra para la defensa de la ciudad y de la isla de Mallorca, cuando y por cuanto la comune ciuitatis estimara que debía hacerse. De eso se infiere que -a diferencia de los bienes de realengo- estaban exentos en los otros conceptos, como de hecho se había declarado en la confirmación de las franquezas de 22 de marzo de 1233.

Si Jaume I les había declarado en 1269 sujetos a los subsidios vecinales por lo que poseyeran en el realengo y a gastos de reparación de murallas, vigilancia y defensa por todas sus posesiones o caballerías, en la sentencia de Lérida del 12 de marzo de $1274^{25}$, cuándo declaraba haber recibido otro subsidio de importe desconocido por ahora, encontrará ocasión para insistir en que los militares, como todos los habitantes, tenían que contribuir siempre a la reparación de murallas y a la defensa de la tierra y que los caballeros tendrían que contribuir siempre a armadas y a vigilancia (atalayas y vigías). La demanda de los caudales de la isla parece, pues, ir siempre ligada a la seguridad de que los caballeros no quedarían del todo fuera del contingente de los imponentes.

El 15 de mayo de 1321 los "priuilegiati quam non priuilegiati cuiuscumque gradus et condiciones existant" son incluidos en la obligación de tributar en una "contributio uel collecta" para cubrir donativos al monarca y sólo se exceptúa, por descontado, a los "clericis, militaribus personis" y familiares reales que no fueran de la isla de Mallorca; pero el 22 de noviembre de 1327 les eximieron, junto con los clérigos y los familiares del rey, de una "talla seu cabesagio" que habían impuesto a todos los habitantes de la isla.

Tan dependiente es su dominio que la transferencia de posesiones sin autorización del monarca provocó a menudo confiscaciones, por mucho que algunas veces se resolvió mediante composición monetaria, como veremos más adelante.

Aunque les confieren un tratamiento respetuoso y les aceptan como hombres de honor en las fianzas judiciales, por la sentencia del Abad de Ribagorza del 21 de noviembre de 1289 les denegaban que pudieran ser juzgados sólo por caballeros y la inmunidad en el embargo de caballo, de utensilios y de ropas de casa. Sólo están explícitamente exentos del monedaje septenal instituido en $1309^{26}$ y de las tallas ordinarias y las contribuciones comunes, es decir, de las impuestas para los gastos ordinarios de los jurados, pero no están libres si los tributos son por razón de defensa o de interés vital

\footnotetext{
${ }^{25}$ ARM Códice dels Reis f. 3 v y 34 y Códice Sant Pere f. 6 y 87.

${ }^{26}$ Álvaro SANTAMARÍA, Demografía de Mallorca. Análisis del morabatín de 1329, "Mayurqa", 20 (Palma, 1981-84). El "monedaje". o "morabatí" era una imposición que tenían que abonar cada 7 años todos aquellos que tuvieran bienes que sobrepasaran las 10 libras; fue instituido por Jaume II en Mallorca el 25 de marzo de 1301, a imitación del que había establecido Jaume I en Valencia en 1266, y a cambio de que el monarca garantizara no alterar la paridad monetaria en el futuro; en 1309 se dictaron las correspondientes normas de aplicación. Vid. también Cronicón.
} 
para la isla o por interés militar, de vigilancia o de conservación de las fortificaciones, ni tampoco están exentos de contribución por aquello que produzcan, negocien, pongan a la venta o incluso, muchas veces, por aquello que adquieran para su consumo, ni poseen ninguna inmunidad fiscal por los bienes por cuya adquisición -por herencia, legado, mutuo o cualquier otro subterfugio- hubieran rebasado los 500 morabatines que tienen autorizados como valor máximo de sus posesiones territoriales en la isla.

Por cuanto la posesión de porciones o de rentas en dinero va anexa a la obligación de mantener y presentar caballos armados -bien por sus porciones nobiliarias o fracción, bien de aquellos que le pertenece prestar al rey, que se les ha transferido la obligación por cualquier medio- su dominio se suele llamar "caballería", lo que hace que su condición sea asimilada a la de caballero -sin que por eso se conozca el rito de ingreso en la orden de tal-, que se adquiere por la sucesión en la titularidad del dominio ${ }^{27}$.

La denominación que generalmente les aplican es la de caballeros militares, con carácter casi sinónimo, y sus porciones se llaman "baronías, caballerías o cabdalies". De acuerdo con la tradición, algunas son adjetivadas por la porción del repartimiento de la isla de que forman parte; otras son denominadas "honores" por su carácter de posesión inmueble recibida como pago de servicios con carácter libre de toda sujeción formal o económica (aunque siempre bajo la dependencia jurisdiccional) y la mayoría son "posesiones" o "heredades". Este carácter alodial hará que los términos "alodio" o "posesión alodial" o "señor alodial" se generalicen y que por todo el siglo XV se tienda a convertir en un timbre de calidad la adjunción al patronímico del topónimo de sus posesiones.

Sólo en un caso se conoce la cesión, por parte del monarca Jaume III, de mero y mixto imperio: lo hizo sobre la villa de Buñola, con rango de baronía, a Arnau de Cardellach, que era su actual lugarteniente, con carácter hereditario y derecho a recibir 5000 sueldos (250 libras) anuales sobre todas sus rentas y a ejercer la jurisdicción alta y baja, la justicia civil y criminal, a erigir "costellum ferreum" y a poder ejecutar o azotar a los habitantes, de acuerdo a los crímenes cometidos; todo ello a cambio de la prestación de 5 caballos armados. Aún así, en el mismo documento el monarca reconoce que los otros "capdales et barones" de la isla no tienen jurisdicción criminal en sus posesiones, puesto que la ejerce el veguer real en nombre del monarca ${ }^{28}$. Este caso singular no sirvió, sin duda, de precedente, ya que cuando Francesc Font

\footnotetext{
${ }^{27}$ Sólo conocemos dos casos de investidura por parte de Jaume I: el hijo del conde alemán Carroç, que había sido experto marinero y participado en la conquista de Mallorca, que lo invistió el día antes del asalto a la ciudad (lo menciona la cónica de Bernat DESCLOT en el cap. XLVI, aunque el rey no lo hace en su crónica o "Llibre dels feits"); y un documento dado en Lérida el 22-3-1233 por el que nombraba caballero a $R$. de Montaner, por influencia de su pariente Nuño Sanç y en pago de los servicios que había prestado en la conquista de la isla, que parecen haber sido más de carácter administrativo o de organización que militares, pues no lo mencionan en las crónicas pero en la investidura se dice que "inde (en la toma de Mallorca), omni studio in cunctis nostris negociis elaborarunt". Vid. para este último HUICI; CABANES, Documentos de Jaime I de Aragón, I, doc, 179, p. 130, ed. Anubar, Zaragoza, 1982.

${ }^{28}$ Documenta, doc. 130.
} 
intentó, en 1322, someter a su justicia la villa de Sóller plantando un cadalso en el centro de la población para atemorizar los vecinos, los oficiales reales, con un pelotón de 47 hombres a caballo, se presentaron en ella para hacerle desistir de su intento ${ }^{29}$

En una segunda fase, la monarquía intentó incluso acumular la mayor parte de los dominios, por confiscación, herencia o compra, y así fue como antes de 1315 llegó a concentrar entre dos tercios y un $70 \%$ de las posesiones insulares y a intervenir en la renta de las otras cuando alcanzó a compartir la fracción de los diezmos debidos a la iglesia diocesana ${ }^{30}$

${ }^{29}$ P. Cateura, Política y finanzas, op. cit. p. 84.

${ }^{30}$ En el reparto de la isla inmediato a la conquista cristiana, la distribución en "caballerías", de las que cada 130 suponían la obligación de mantener un caballo armado, había sido lả siguiente:

\begin{tabular}{llll} 
& caballerías & $\%$ & caballos armados \\
Rey ........................... & $\frac{7.674,5}{4.766,5}$ & 42,22 & 43,25 \\
Otros señores.............. & 13.441 & 5778 & 57,25 \\
\hline 100 & 100
\end{tabular}

La "caballería" era una agrupación de alquerías y rahales de magnitud inexacta, pero que se solía aproximar a las 2 jovadas = 32 cuarteradas o 2.273 Has. Entre 1242 y 1310, la monarquía de Mallorca (primero el Infante Jaume, como heredero del reino y después como primer rey privativo, y después su hijo Sanxo) siguió un proceso de incorporación de dominios señoriales que habria supuesto, según SANTAMARIA, el paso de la porción real de un 42 '22\% a un 67' $02 \%$ de la superficie insular. A esta concentración se tendrían que añadir parte de los bienes de la extinguida Orden del Temple, desde 1312 evaluado por el mismo autor en un 2,44\% de la isla, y por lo tanto el patrimonio real habría llegado a un 69 ' $46 \%$ de la superficie útil insular. Si aceptamos que la dotación territorial a la Iglesia de la décima parte de las posesiones que se había pactado antes de la conquista hubiera sido regular, los totales porcentuales obtenidos sobre la base de la distribución primera de "caballerías" tendrían que ser sometidos a corrección y quedarían establecidos de la siguiente manera:

$$
\text { Dotación a } \quad \text { resto de }
$$

Porción la Iglesia la porción 38 Incorporaciones Total

\begin{tabular}{lll} 
Real..... & $42,22 \%$ \\
Otros.... $57,78 \%-5,22 \%$ & $=38 \%+25,24 \%=$ & $63,24 \%$ \\
\hline & $26776 \%$
\end{tabular}

$$
100 \text { '00 \% }=10,00 \%+90^{\prime} 00 \quad 100 \%
$$

Por otro lado, en el segundo cuarto del siglo XIV, después de las incorporaciones y de toda una gama de cesiones, donaciones, cambios, etc. en lọs dominios señoriales, nos consta documentalmente que el realengo tenía a su cargo la prestación de 68' 5 de los 100 ' 5 caballos armados que tenían que estar permanentemente dispuestos para la defensa de la isla. Si esta prestación tuviera una relación directa con la superficie de cada dominio (lo que no puede ser cierto si no es muy aproximadamente) la distribución habría sido la siguiente:

\section{$\underline{\text { Caballos armados }} \quad \underline{\text { Superficie de la isla }}$}

$\begin{array}{llll}\text { Realengo: } & & \text { Total } & \\ \quad \text { Porción Real } & 43,25 & 68,50 \% & 61,34 \% \\ \text { Incorporaciones } & 25,25 & 32,00 \% & 28,66 \% \\ \text { Porciones señoriales } & & & 10,00 \% \\ \text { Porción temporal } & & & \end{array}$

De acuerdo con ambas vías de cálculo, pues, el total de las porciones señoriales, deducida la porción del "décimo" diocesano y las diferentes incorporaciones al realengo, no llegaría mucho más allá de un $25 \%$ del territorio, mientras que la porción real abarcaba, con toda seguridad, poco más de un $60 \%$. 
Además de una cierta política de importantes confiscaciones de bienes señoriales emprendida por los monarcas de la isla ${ }^{31}$ los reyes de Mallorca hicieron uso, también, del recurso de crear nuevas caballerías con el fin de transferir la carga de una parte de los caballos armados que estaban obligados a mantener por su parte proporcional del territorio. Algunas no tuvieron nunca contenido territorial de ningún tipo y fueron formalizadas en dinero. Aunque al monarca le pertenecía en principio la prestación de 43'25 de los 100 '5 caballos armados que se habían establecido por la defensa de la isla, con las incorporaciones sucesivas llegaron a ser 68'5, que en 1332 estaban repartidos de esta manera:

-por los barones antiguos (establecidos por Jaume II): 13

-establecidos por el rey Sancho: 11,5

-por otros caballeros, a sueldo del real patrimonio: 21

-a cargo del mismo monarca: 22,5

(incluidos los 5 que tenía que prestar Arnau de Cardellac por Jaume III)

Estos privilegiados, que perciben en sus porciones "antiguas" la mitad del diezmo, deducido un $25 \%$ para la parroquia local (es decir, en el caso de granos y legumbres, un 3 ' $75 \%$ de lo producido), además de la tasca de un 7' $5 \%$, y un poco menos en el vino y las hortalizas ${ }^{32}$, no reúnen fuera del realengo más allá de un $20 \%$ del territorio. Desde comienzos del siglo XIV se agrupan en una Cofradía para la cual el "milite" Jaume de Santacília les cedió en $1329^{33}$ un lugar donde reunirse pero que hasta 1490 no fue reconocida por Joan II, que les autorizó a instalarse en la lonja de los genoveses, y que decayó pronto, porque se tuvo que reestructurar en 1515 y en 1577 y a principios del siglo siguiente quedaba sin actividad y casi sin afiliados. Fue restaurada en 1690, cuando la tuvieron que abrir a mercaderes recientemente ennoblecidos, y acabó siendo abolida por disposición real en 1778.

Por mucho que los privilegiados tuvieran la exención en impuestos directos o "tallas", no siempre les dispensaron de pagarlas. El 6 de septiembre de 1339 se declaró que, al igual que clérigos y extranjeros, estaban obligados a las ayudas que fueran impuestas para la defensa de Mallorca y, ante el

${ }^{31} \mathrm{P}$. CATEURA, Mallorca y la política patrimonial de la monarquía, "Estudis Baleàrics", 27, p.11, Palma de Mallorca, 1987. Confiscaciones conocidas son: -el ejercicio del dominio eminente en la compra de los bienes del Orden del Santo Sepulcro -1280que el año siguiente los transfirieron a Guillermó de Puigdorfila

-la de los bienes de la Orden de San Jordi d'Alfama -1300-

-la de una parte de los bienes del Orden del Temple, que negociaron su transferencia a la Orden del Hospital -1314-, alegando que le habían sido transferidas sin la autorización real posesiones de Guillem Montcada, Raimón de Alamany y G. De Claramunt

-la de los bienes de Gastón de Bearn -1306/7-

-y las de los bienes de Huc de Empúries, cuya transferencia sería autorizada después -1318-.

${ }^{32}$ Las tasas aplicadas generalmente por concepto de diezmo, en Mallorca, son las siguientes: Grano y legumbres: $1 / 10=10^{\prime} 00 \%$

Vino, hortaliza y forrajes al por mayor $1 / 11=9^{\prime} 09 \%$

Aceite: $1 / 12^{\prime} 5=88^{\prime} 00 \%$

Lino, azafrán y forrajes al por menor:1/13 = 7'61\%

Ganado: $1 / 15=6{ }^{\prime} 66 \%$

En cereal, vino y aceite se deducía del diezmo una cuarta parte para la parroquia local.

${ }^{33}$ ARM Códice Sant Jordi, f. 103. Pedro MonTANer, La estructura del brazo noble mallorquín bajo los Austrias, "Estudis Baleàrics", 27, p. 11. 
recurso que habían presentado porque los jurados les habían cargado algunas imposiciones y ayudas, les invocaban antecedentes por los que el mismo Consejo real les había declarado obligados a contribuir en tallas para defensa de la isla, provisión de trigo, defensa y armadas contra piratas y enemigos de la fe católica y para murallas y obras de acueductos, puesto que todo eso era en beneficio también de los mismos privilegiados; por lo tanto, les denegaban la restitución de cantidades que solicitaban y la declaración de exención para el futuro. Aunque se aceptaba que estuvieran exentos de las ayudas en lo sucesivo en aquellos casos en que no se viera la urgente necesidad pública ni el peligro para la seguridad de la isla, el monarca se reservaba la posibilidad de decidir la contribución en casos urgentes, de acuerdo con las circunstancias.

Cuando Pere IV entró en la isla el 31 de mayo de 1343 declaró inmediatamente que "nullum de civitate vel insula predicta privilegiamus, vel quo modo libet eximamus, quin exsolvat en sumptibus communibus quibuscumque", disposición que originó una inmediata comisión de representantes de los "militum, generosorum et priuilegiatorum", a la cual prometió sólo, de manera formularía y sin ningún compromiso (28-3-1344), mantenerles en los antiguos privilegios, franquezas, usos y costumbres, es decir, no hacer nada nuevo para ellos.

A veces quieren hacer pasar por ofrecimiento "voluntario" su contribución en algunas ayudas, para afianzar la presunción de exenciones inexistentes o poco consistentes y por afán de no dejar precedentes. Es el caso de las ayudas que se impusieron para la defensa de la isla contra el rey del Algarbe y contra el anterior monarca Jaume III (el 29 de marzo de 1347 y el 6 de enero de 1349), que cada vez les hicieron tributar bajo la declaración real de que no se les tomaría en cuenta el precedente para el futuro ni se les obligaría a contribuir a cualquier impuesto que no fuera para defensa. Al mismo tiempo, sin embargo, el monarca solicitó información de su gobernador en la isla (13 de junio de 1349) sobre si habían cotizado antes o si estaban obligados a hacerlo y si era cierto que habían contribuido en dos ocasiones recientes en las contribuciones sobre vino, ropa y molienda y que procedían a vender por si mismos su propio vino.

Otras veces, como en 1356 para la guerra de Castilla y para el viaje a Cerdeña del monarca, el 1 de febrero de 1357, se ofrecen a tributar aparte, mediante cantidad global alzada, a título de concesión graciosa, pero fuera del control de los jurados. Pere IV, siempre necesitado de caudales, no pierde ocasión de ningún tipo, y es así como obtienen la oportunista declaración dirigida a los jurados -que habrían querido que participaran en las ayudas comunes de la isla con mayor motivo que en las empresas externas del monarca- de que no los estorbaran en su contribución, puesto que se trataba de gastos de tipo militar (aunque no propiamente de la defensa de la isla).

Desde estos momentos, las querellas de los generosos, militares y privilegiados con los jurados y ante el mismo monarca son continuas y reiteradas pero el 6 de marzo de 1363 ya tuvo que declarar aquél que no se tenían que considerar exentos de las colectas universales aquellos que 
ostentaran privilegio militar y que no pudieran acreditar el contenido territorial que llevaba incluida la exención, ni los que disfrutaran de privilegio de "generosorum" (de linaje o raigambre) sólo por el hecho de poseer arma o caballo, dado que había ciudadanos y vecinos que también los poseían. Esta disposición nos indica la existencia de un subterfugio que se haría habitual en el futuro, como es la pretensión de cualquiera que poseyera caballos y armas y que cazara con halcones, de ser considerado privilegiado, por mucho que estos lujos estuviesen al alcance de algunos rústicos enriquecidos como de hecho nos lo testimoniará más tarde un proceso entre la parte foránea y la ciudad del año $1477^{34}$.

Ante esta terminante declaración real, inmediatamente los caballeros remitieron una delegación al monarca, que estaba en la huerta de Burriana, desde donde asediaba Valencia mientras estaba cercado por las tropas castellanas. El delegado de los barones obtuvo la declaración del 15 de julio de 1364 que decía que sólo el monarca decidiría cuando se tendría que solicitar la ayuda económica de los caballeros -que se distribuirían entre ellos nominalmente y siempre en casos de necesidades extremas-, y que no tenían que estar incluidos en las ayudas comunes ni sometidos a la físcalización del Consejo General de la isla. Sin embargo, tendrían que contribuir siempre en armadas, murallas y acequias de agua.

Aún así, las continuas y perentorias necesidades y exigencias de capitales formuladas por el monarca empujaban a los jurados a exigir una vez y otra, mediante amenazas de ejecución de los bienes, la contribución del estamento militar, de la que tenían bastantes antecedentes que invocar, y les obligaba a recibir pliegos y pliegos de protestas, recursos y pleitos.

El rey, irritado por las demoras que todo aquello originaba a sus continuas peticiones de caudales, obligó el estamento militar, el 3 de enero de 1366, a abonar los gastos de escribanos y otros causados por una alegación en la que se negaban a contribuir en las derramas generales; el 17 de agosto les declaró obligados en el pago de una talla impuesta para la guerra de Cerdeña, a pesar de sus recursos pidiendo pasar cuentas de contribuciones anteriores que, sin duda, no estaban lo bastantes claras; lo confirmó el 18 de agosto, basándose en las sentencias de Jaume I de 1274 y de Alfons II de 1289 y de $1290 \mathrm{y}$, ante la protesta de los privilegiados por el hecho de que sus eventuales contribuciones para la defensa eran destinadas a otras finalidades (5 de septiembre de 1366), insistió en la obligación de respetar la sentencia: tenían que contribuir a todas las colectas que se fijaran para utilidad del reino, pero no a otras.

Todo eso no rebajó ni las protestas y continuos recursos de los privilegiados ni las pretensiones y los intentos de los jurados de declarar de extrema urgencia y de interés defensivo cualquier imposición, dado que alimentaban las contribuciones hechas al monarca para gastos bélicos y de defensa del reino aragonés.

\footnotetext{
${ }^{34} \mathrm{ARM}$ AH 4120.
} 
Las reclamaciones no tenían fin y el 27 de septiembre de 1366 el monarca ordenó que se constituyera un tribunal imparcial para estudiar las protestas de los privilegiados. De aquel tribunal surgiría la declaración del 29 de diciembre que confirmaba que, en aplicación de las anteriores disposiciones y sentencias, los militares, generosos y privilegiados tenían que contribuir en armadas, atalayas, vigías y otros gastos precisos para la defensa de la isla y en todos los casos incluidos en las sentencias; los declaraban libres, sin embargo, de cualquier otra contribución para utilidad de la ciudad o reino, aunque no estaban inmunes en los dones o profertes por los brazos militar y el de ciudadanos que, como era habitual, el reino hacía al monarca de forma parecida a los que le hacían las Cortes de Aragón, Cataluña o Valencia o de los obtenidos en las Cortes de Monzón de 1363.

En adelante (22 de julio de 1367) les tendrían que citar expresamente con el fin de obtener su contribución en las colectas a utilidad del reino que fueran diferentes de las incluidas en los casos expuestos.

El 12 de enero de 1368 la cancillería de Pere IV tuvo que emitir una nueva y extensa sentencia donde se declaraba que los privilegiados tenían que cotizar como los otros habitantes de la ciudad y del reino por todos los bienes que poseyeran, o que hubieran poseído, en la porción del rey y por las otras porciones que fueran de capitales, de eclesiásticos o de otros cualquiera; que estaban parcialmente exentos sólo por sus caballerías antiguas o por las posesiones adquiridas dentro del límite de los 500 morabatines, por las que tendrían que contribuir sólo por los conceptos ya detallados en anteriores sentencias. El monarca confirmaba la disposición de 29 de diciembre de 1366 y ordenaba que no se tenían que someter a los capítulos y ordenaciones hechas por los jurados más allá de lo que contenían las mencionadas sentencias; se creaba de nuevo una comisión de dos componentes del brazo militar y dos de los ciudadanos o de los mercaderes para estudiar los casos en que los militares y privilegiados tenían que contribuir y, al mismo tiempo, les aumentaba a 500 reales (o libras) de Mallorca los 500 morabatines (200 libras) que limitaban su capacidad de adquirir bienes raíces que, si en el futuro pasaban a manos de personas no militares o privilegiadas, perderían todo el derecho a exención: es decir, quedaba claro que la exención era personal, no ligada a la finca, como a menudo los ocupantes de algún dominio querían dar a entender. Por fin, el rey declaraba que tenían que contribuir en todas las imposiciones y ayudas siempre que los jurados hubieran obtenido la autorización real para hacerlo, y se reservaba el derecho de obligarles en cualquier momento, de acuerdo con el interés del caso.

Ante nuevas alegaciones de los militares -que, claro está, no alcanzaban nunca una declaración clara y terminante de total inmunidad en las cargas comunes- el monarca tendría que aclarar que el término "colecta" que había utilizado incluía cualquier tipo de acción recaudadora, fuera peita, ayuda común, questia, exacción o imposición, o con cualquier otro nombre que le atribuyeran. El 4 de diciembre de 1368 añadió que la franquicia de los privilegiados se extendería sólo a las caballerías que hubieran incrementado su patrimonio dentro del margen de los 500 "aureos" que les había sido 
impuesto y que por todo aquello que consumieran para uso propio tendrían que abonar, como todo el mundo, las imposiciones y las ayudas comunes.

La siguiente estrategia de los privilegiados consistió en negar retroactividad a estas declaraciones terminantes, a oponerse a contribuir a las ayudas destinadas a enjugar las enormes deudas contraidas desde años atrás por el reino y a negarse a ser acosados por el ejecutor de la juraría. El monarca les sacó pronto de su error: después de afirmar de forma dubitativa (6 de febrero de 1369) que la anterior disposición de enero de 1368 no era de aplicación retroactiva a los casos que no fuera costumbre que contribuyeran, y de dejar pendiente de resolución la controversia, el 23 de julio de 1370 aclaró definitivamente las sentencias de diciembre de 1366 y del 12 de enero de 1368 en el sentido que su intención era que contribuyeran por todo aquello que poseyeran, hubieran tenido o poseído o tuvieran y poseyeran en el futuro, tanto en la porción real como en porciones de prelados, de personajes capitales o de otras personas que no fueran exentas de los "comuni vicinali", y también a todas las contribuciones impuestas o que se impusieran en el futuro; que la inmunidad que les correspondía se refería sólo a las caballerías antiguas y a las compras efectuadas dentro del límite de los 500 "aureos" o su equivalente -hubieran sido o no de realengo-; que, sin embargo, estaban obligados a contribuir en gastos de defensa, escuchas, atalayas, dones y profertas hechas al monarca y otras causas expresadas en las sentencias.

Añadía que tenían que contribuir igual que cualquier otro habitante por todo aquello que negociaran o pusieran en venta o en el mercado, directamente o por medio de familiares, igual que cualquier otro de la isla y sin distinción en los frutos, tanto si procedían de caballerías antiguas como de las adquiridas dentro del límite de los 500 "áureos", de acuerdo con el espíritu de lo que había provisto el rey conquistador en 1269. Les advertía que tenían que eludir los intentos de fraude como era el declarar (falsamente) que el destino de los productos era el consumo propio, o negociarlos en la parte foránea para zafarse de la fiscalidad ciudadana, ya que si se hubieran puesto en circulación en la ciudad habrían tenido que abonar las tasas impositivas correspondientes. Para acabar, declaraba el carácter retroactivo de esta obligación.

\subsection{Eclesiásticos}

Los eclesiásticos, paradigma de la exención, tampoco estaban libres de la obligación de tributar en tallas, questies, ayudas, imposiciones y otras exacciones, si por algún medio habían llegado a entrar en posesión de tierras de realengo, a pesar de la prohibición de las franquezas de que pudieran adquirir bienes.

Por mucho que están explícitamente exentos de cualquier imposición, de monedaje (23 de marzo de 1300) y de tallas "seu cabessatgio" (22 de noviembre de 1327), en ocasiones de peligro para la paz de la isla también les obligaban a contribuir. Jaume I, el 23 de julio de 1269, les declaró obligados a contribuir en gastos para defensa y reparación de murallas; por la sentencia 
de $1288^{35}$, junto con los caballeros, abogados, jueces, médicos y viudas de caballeros, les declararon obligados a contribuir en gastos de armadas. El 28 de mayo de 1328 hicieron contribuir a todos aquellos que poseyeran, por cualquier título o medio, bienes patrimoniales o "beneficios" eclesiásticos ${ }^{36}$ a una questia impuesta para enjugar las deudas de la isla. El 9 de julio de 1339 les obligaron a las ayudas impuestas para la defensa del reino, junto con los privilegiados y los extranjeros, y a la defensa de la isla y la conservación de murallas. El 10 de marzo de 1363 incluyeron también al obispo en la obligación de cotizar. Incluso les amenazaron con el secuestro de sus bienes (como pasó el 22 de octubre de 1358, para la guerra de Castilla, que los asimilaron a los barones reticentes de Cataluña de que habían tratado las Cortes) o bien le será humildemente solicitada al obispo la contribución, como el 1 de diciembre de 1360, lo que suscitó una inmediata oposición de la jerarquía eclesiástica ${ }^{37}$, tanto a las peticiones como a las mismas "generalidades" votadas por las cortes de Monzón (14-11-1377).

De manera sistemática -cómo pasó el 24 de diciembre de 1364- la corona tuvo que confiscar, sobre todo, los bienes de los eclesiásticos que residían fuera de la isla.

$\mathrm{Su}$ resistencia a abonar lloïsmes (laudemios) al real patrimonio ${ }^{38} \mathrm{se}$ empareja con su tendencia a adquirir bienes de la porción real -que les estaba prohibido- lo que motivó que Pere IV dictaminara el 28 de julio de 1367 (de acuerdo con lo que había ordenado Jaume I el 1 de junio de 1242) que en caso de que se negaran a contribuir por estos conceptos, tendrían que transferir los

${ }^{35}$ ARM Códice Roselló Vell f. 170 y Rosselló Nou f. 120 v.

36"BSAL" XI p. 67.

${ }^{37}$ ARM LR 22 f. 220. Desde de Almunia, el 13-4-1361, protestaba el rey de estar detenida la concesión de 24.000 libras de Barcelona por dos años, para levantar a 200 hombres armados, obtenida por el acuerdo de Poblet del 5-8-1360, a causa del retraso de los representantes de Menorca en remitir su aportación y de la oposición del obispo a la tributación de los eclesiásticos.

${ }^{38}$ El 10-4-1335 Jaume III de Mallorca dictaba, en Perpiñán, una nueva disposición que confirmaba las anteriores prohibiciones a los eclesiásticos de adquirir bienes, $\mathrm{y}$ ordenaba que cualquier súbdito que quisiera transmitir -bien de manera onerosa o gratuita, tanto en vida como "post mortem"-, bienes que se tuvieran por cesión y bajo dominio del monarca, a favor de instituciones o de personas eclesiásticas exentas de contribuir a las tallas o colectas tendría que abonar al fisco real un 1/4 del precio o valor de los bienes transferidos; si los susodichos bienes no fueran de dominio real y. se tuvieran en alodio por otro señor temporal, tendrían que pagar 1/6 parte; si fueran de dominio eclesiástico, no tendrían que pagar nada. Para Mallorca, estas tasas se fijaban en importes superiores, en consideración a que se trataba de un lugar estratégico $\mathrm{y}$ en peligro de quedar despoblada si proliferaban estas transacciones o concentraciones de bienes raíces:

Bienes de dominio real: $1 / 3$ del valor

Bienes de dominio alodial: $1 / 4$ del valor

Bienes de dominio eclesiástico: $1 / 4$ del valor

Una provisión de Pere IV dada el 1 de diciembre de 1350 revocó esta disposición, aunque exigiendo que los deudores abonaran lo que debían según aquella hạsta el momento.

En todas las épocas, y en la porción real o allí donde había condominio real, el fraude contra el laudemio era uno de los que más menudeaban, y también las transmisiones de bienes sin declarar, con el fin de no tener que abonar al Patrimonio Real la fracción que le correspondiera, prácticá especialmente ejercida por los eclesiásticos, que se consideraban, de hecho, ajeno a la jurisdicción real. Cuando Joan I, en 1390, concedió a instancia del notario Castell, enviado por los jurados de la isla -y mediante un soborno en figura de préstamo-, entre otros capítulos, la anulación de los numerosos comisos en los que habian incurrido los pobladores de Mallorca por ésta causa, excluyó a clérigos y personas eclesiásticas sobre las que, afirmaba, quería ejercer todo su poder y su derecho. Vid. Cronicón, p. 46, 64 y 77. 
bienes a manos laicas en un plazo inferior a 4 meses $^{39}$, hasta que se llegó a confiscaciones como las que ya se habían dado en 1361. Todas estas prohibiciones se reiteraron el 14 de abril de 1380.

\subsection{Ciudadanos}

Existen también noticias a ciertas ventajas fiscales de los ciudadanos, que eran tal vez las que impulsaban a tantos poseedores de fincas de la parte foránea a fingirse residentes en la ciudad. Estos intentos de fraude y las acusaciones que motivaban fueron las que dieron el motivo para la sentencia del Abad de Arlés de 1332 y para que los jurados de la ciudad tuvieran que reclamar un privilegio específico -que obtendrían a cambio de las concesiones hechas a Pere IV en las Cortes de Monzón (27-3-1376)- para que se obligara a aquellos supuestos habitantes de la ciudad a vivir en ella un mínimo de tres meses, para prevenir el caso de que su único objetivo para fingirse residentes en la urbe fuera rehuir la tributación en la parroquia respectiva.

Entre estos privilegios fiscales parece que la exención de "lezda, pedatico, portalico, mensuratico et penso et ribatico" dictada para los pobladores en el punto 3 de las Franquezas fue aplicada sólo a los habitantes de la ciudad ${ }^{40}$, que al principio es identificada con la isla y, por lo tanto, con el reducto donde radican los agentes económicos.

Otros beneficios para los residentes en la ciudad podían derivar de diferencias en las contribuciones sobre el consumo y el intercambio de mercancías, de las que los diversos capítulos de las imposiciones que conocemos nos dan algún indicio: los impuestos generales sobre el consumo contenían siempre conceptos específicos para algunas producciones de la parte foránea, diferentes de los de la ciudad: se distinguía entre el contribuyente de la ciudad, considerado intermediario o bien simple consumidor, del foráneo, considerado, además, productor y proveedor y, por lo tanto, generador de la verdadera fuente de recursos. Así, sobre todo los capítulos de la "molige" distinguen tasas sobre consumo y fabricación de pan diferentes para la ciudad y la parte foránea; los de la compra-venta de vino en la ciudad son de 3 dineros por libra (un 1,23\%), mientras que es $1 / 6$ (un 16 '66\%) de lo producido, recolectado o vendido en la parte foránea; y también es diferenciada la "sise" de las carnes (sobre el despiece o en la compra para el consumo) que es privativa de la ciudad, ya que en la parroquia de origen se pagaba

${ }^{39} \mathrm{P}$. CATEURA, Política y finanzas op. cit., doc. 124. ARM Códice Sindicat de Fora XIV f 40; Id. XV f. 55 v: Códex Abelló f. 222;'RP 395; José María QUADRADO, Privilegios y Franquícias de Mallorca, Escuela tipográfica Provincial, Palma de Mallorca, 1894, pág. 242; Bernardino BAUZÀ, Por la Ivnta, op. cit. p. 130.

${ }^{40}$ ARM Códice Jurisdiccions e Stils f. 37. Como ya se ha visto en la nota 15 y a tenor de la indagación hecha por el rey Pere IV, según declaración que consta en el documento de 29-1-1345, que le impulsó a disponer el 31 de mayo del mismo año que se hiciera extensiva la exención a los foráneos. Este podria ser ya un capítulo importante: la exención vendía dada por las franquezas, pero parece que sólo se aplicaba a los ciudadanos, quizás porque los habitantes del campo no tenían consideración de beneficiarios de privilegios, ya que les había sido denegada la exención y les habían obligado a pagar provt consueverunt en la reforma de las franquezas de 31-1-1300. 
impuesto sobre el ganado y sobre el despiece y compra-venta de animales y de carne. Sin embargo, sobre todo, en las parroquias foráneas se pagan, además de las habituales, imposiciones sobre producción y compra-venta de aceite, lana, quesos, frutos secos, miel, manteca, ganado y animales de todo tipo -excepto el de labor, pero incluyendo cabalgaduras o animales de carga-, cautivos, venta de posesiones o de arriendos, mercancías a peso, cosechas, cueros y pieles; y todo eso, en el caso de ser puesto en venta en la ciudad (bien para la exportación, o bien para la venta al por menor o para la transformación), tenía que abonar otra vez 2 dineros por libra para cada contratante. Si los dos procesos (compra-venta en el lugar de producción y compra-venta en el mercado ciudadano) podían reducirse a uno solo el beneficio era indudable.

El motivo principal, sin embargo, podía ser que los jurados de las villas imponían también tallas o subsidios vecinales para las necesidades locales o para embajadas al monarca, obsequios, pleitos, procuradores, desplazamientos, gramallas, obras públicas y de defensa, etc., de las cuales podía zafarse el poseedor rural que habitara en la ciudad pero que, por el hecho de no tener estatuto de ciudadano ni residencia permanente en aquélla, no figurara tampoco en las listas de los contribuyentes ciudadanos.

Una última posibilidad todavía es que el señor rural habitante de la ciudad cotizara sólo por aquello que consumiera en su domicilio ciudadano y se ahorrara la tributación por lo que se produjera en sus fincas, haciéndolo pasar por productos para su consumo privado; en este caso estaban exentas, entre otros, hilaturas, granos, compras de ganado, lana y quesos, leña y carbón, lino y estopa, que después sin duda tendrían que ser vendidos bajo mano. Tanto es así que Pere IV, en la sentencia de 23 de julio de 1370, tuvo que advertir a los privilegiados respecto de este tipo de fraude que, por lo que se ve, menudeaba sobre todo en comestibles y bebidas.

\section{LA EVOLUCIÓN DEL SISTEMA FISCAL}

En términos generales, el término subsidio, se aplica a colectas capitativas como son las tallas y todas las colectas que eran adjetivadas de "vecinales" (comuni vicinatico, servicio vecinal, tallas vecinales, adiutorium vicinale...), mientras que las ayudas, genéricamente llamadas "imposiciones", se suelen aplicar sobre el consumo y con el tiempo se denominaría cada una "derecho" (derecho del vino, de la carne, de cautivos y censales... etc.), y constituyen un nuevo recurso arbitrado a solicitud de los jurados, por cuanto no estaban expresamente contenidas en las prohibiciones de imponer cargas sin el "placet" del lugarteniente o del monarca como la que les había hecho Jaume II en la confirmación y recopilación de las franquezas de 1300, que se había referido brevemente sólo a las "colectam seu exaccionem", términos reservados a subsidios como la talla u otros impuestos directos.

El término servicio denomina las cantidades que se debían hacer llegar al monarca, a veces en concepto de dones u ofrendas, es decir, que describe 
la finalidad del capital, que puede haber sido obtenido de numerosas fuentes, desde el préstamo o el donativo hasta las imposiciones.

Dentro de los dos grandes bloques de Subsidios y Ayudas, encontraremos a menudo diversas denominaciones:

\subsection{Subsidios}

Talla, cabassagio, questia, colecta o peyta.- Para las necesidades extraordinarias se utilizaba el sistema, digamos inmediato -que no pasa por las imposiciones- en los casos en los que la cantidad se extraía directamente en forma de "colecta" o "talla", por mucho que el recurso a la talla extraordinaria sería también el que utilizarían (complementariamente o en exclusiva) para "servicis" o "dons" al monarca para levantar tropas, desde el inicio de la guerra de Castilla en 1357.

De este tipo de tributación se consideraban exentos los caballeros, militares y eclesiásticos, si bien en todas las épocas las disposiciones reales reiterarán -cómo ya hemos visto- que, puesto que no lo estaban de contribuir en los gastos de defensa, fortificaciones y obras públicas de interés comunitario, tenían que contribuir a algunas tallas en casos de peligro inminente para la isla. A pesar de todo, las protestas, recursos y apelaciones de eclesiásticos y caballeros y de todo tipo de pretendidos exentos se producirán sistemáticamente y con monotonía en todos los casos.

Subsidios vecinales.- Las villas por separado (incluyendo la ciudad como tal), por necesidades de fortificaciones, obras, vigilancia costera y celebraciones públicas, recaudaban "comuni vicinale", "vicinaticos" (tenemos noticias desde 1269) o "subsidios vecinales" mediante derrama entre la población, y lo hacían en forma de colectas -en figura, por lo tanto, de tallasde las que sólo las diferencia su carácter estrictamente local, restringido a los vecinos de la parroquia de residencia.

I. La primera noticia que conocemos -a 7 años de la conquista cristiana- de una "colecta" para las necesidades habituales de la nueva comunidad, es del 25 de mayo de $1237^{41}$. Siete años más tarde (10 de mayo de 1244$)^{42}$ el mismo Jaume I, desde Játiva, disponía, cómo hemos visto, que todos los que poseían o hubieran adquirido bienes dentro de la porción del rey también tenían que contribuir a las "tallas o colectas en beneficio de la ciudad". En 1247, antes de haberse dictado la constitución del organismo rector de la isla, la universidad de Mallorca ofrecía ya al monarca 1200 sueldos melgoreses (900 reales de Valencia) forzosamente obtenidos a derrama o por algún medio de algunos o de todos los pobladores, a cambio de la real licencia para construir una cuartera, una pescadería y los pesos del

\footnotetext{
${ }^{41}$ ARM Códice Sant Pere f. 2 v; Códice dels Reis f. 1 v.

${ }^{42}$ Documento de 10 de mayo de 1244. Vease Álvaro SANTAMARÍA, El gobierno de Olfo de

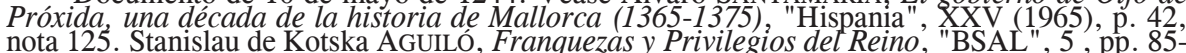
nota 125. Stanislau de Kotska AgUILÓ, Franquezas y Privilegios del Reino, "BSAL" 5 , pp. $85-$
$90:$ tambien en Jaime VILLANUEVA, Viaje literario a las lglesias de España, XXII, Madrid, 1852 ,p. 296.
} 
carbón, la harina, la lana y los quesos, etc ${ }^{43}$. Cuándo en 1249, al día siguiente de que concediera a la universidad de la isla la totalidad de los derechos sobre el puerto (Valencia 7 de julio), el rey creó el organismo rector de la misma (6 jurados con un número arbitrario de consejeros) y lo hacía para "gobernar, administrar y regir toda la isla" y para provecho tanto del monarca como de la comunidad insular. Claro está que uno de los principales objetivos era la obtención de subsidios y de otros tributos por parte de los pobladores que, al ser negociados y distribuidos por sus mismos representantes, no tendrían el aire coercitivo de una imposición hecha a través del lugarteniente real (y, en efecto, no se conocen tallas reales). Al mismo tiempo, constituye el recurso que permitiría al organismo mantenerse a cargo de los pobladores sin representar ningún tipo de carga para el erario real.

No hay, pues, citas explícitas a impuestos propios sobre el consumo ni a las fuentes de financiación de la Universidad, que parece que la tendrían que obtener mediante recaudación de tributos extraordinarios directos (tallas, questias o colectas), incluso en los casos de ofertas o donativos al soberano.

II. Mientras el Infante Jaume ejerce la lugartenencia del reino (12561276) aparecen ya disposiciones relativas a gastos de interés comunitario cono son las obras de defensa y de reparación de las murallas, armadas y guardianes costeros ("atalayes y escoltas"), y también otros dones efectuados al monarca $^{44}$. Para las necesidades de administración y de obras locales de la ciudad ya se recaudaban los "comuni vicinali" o "vicinatico" -y también algunas "tallas" en casos determinados- como la que se dispuso el 23 de julio de 1269 -cuando el monarca obtuvo 50.000 de los 70.000 sueldos que solicitaba por el viaje a Tierra Santa que nunca llegó a hacer-, en el momento que el rey presentaba a su hijo Jaume como heredero del reino de Mallorca y juraba las franquezas, y que declaraba que los "honores" de la porción real tenían que contribuir a los "vicinaticos", lo que reiteró en Lérida el 12 de marzo de 1274, cuando obtuvo otro "servici" -sin cuantificar, de momentode los pobladores.

Confirmando las anteriores disposiciones, Alfons el Lliberal, nada más entrado en Mallorca en nombre de su padre Pere el Gran en 1285, una vez había ezpulsado a Jaume II de su reino, dictó una disposición relativa a la obligación de los "honores de realengo" de contribuir a dichos "subsidios", y aclarando el 4 de octubre de 1290 que lo tenían que hacer también en "atalayes y escoltes".

III. Ya restaurado en 1298 Jaume II de Mallorca en su trono -después de 13 años de ocupación catalana- y a cambio de liberar a los pobladores de la isla del pago de "lleudes, peatges i bovatge" (derecho que se había retenido -junto con la acuñación de moneda en la isla- en los pactos con su hermano mayor Pere y recientemente con su sobrino y superior feudal Jaume II de Aragón) y tal vez en relación con un subsidio o donativo para financiar las

\footnotetext{
${ }^{43}$ Cronicón. Privilegio dado en Teruel el 2-4-1247.

${ }^{44}$ ARM Códice Sant Pere f. 5, 6, 6 v, 7 v, 87 y 115 v; Códice de los Reyes, f. 25 v, 33 v, 34 y 37 ; Códice Privilegios f. 38
} 
obras que deseaba emprender, el 31 de enero de 1300, cuando autorizó una "sisa" sobre algunos artículos (es decir, a repercutir sobre los precios) ${ }^{45} \mathrm{de}$ que tendremos que hablar, somos informados de que en les villas se recaudaban cantidades para obras defensivas, atalayas y vigías, fábrica de iglesias y "solaços e convits" ${ }^{46}$ y que en la ciudad se recibían aparte ciertas "colectas".

En 1309, que finalizaba el periodo por el que había autorizado la "sisa", el rey dictó las normas de recaudación del tributo septenal conocido como "monedatge" -del que estaban francos eclesiásticos y caballeros-, unas regulaciones relativas a las numerosas obras públicas que había impulsado desde principios de siglo (castillos de Bellver, de Capdepera y palacio de Valldemossa, murallas de Alcudia y de Ciutadella, reformas en el palacio del Almudaina, desvío del torrente de la Riera ${ }^{47}$, reconstrucción de la Catedral...), y autorizó diversas recaudaciones de "ayudas vecinales" (prestemos atención al sustantivo, que pertenece a la otra modalidad de tributo) parecidas a los que se habían constituido ya en Menorca e Ibiza y también en forma de "sisa" sobre el consumo.

Pocos meses después (1-7-1309, desde Perpiñán) el rey ordenaba recaudar en la isla, para gastos y obras de utilidad común como eran la conducción de aguas y la reparación de acequias, una "contribución o colecta" denominada "subsidio vecinal" por un total neto de 6000 libras, a distribuir de modo semi-progresivo a proporción de la calidad y el estado de cada habitante capaz de contribuir (los más desvalidos abonarían 1 óbolo semanal) $)^{48}$.

El día 16 del mismo mes, mediante una compensación de 900 libras que le hacían los jurados, Jaume II suprimió el impuesto sobre la carne que recibía en sus territorios de la antigua porción de Nuño Sanç, y que tal vez interfería o entraba en conflicto con las contribuciones que los jurados imponían de forma general en toda la isla sobre aquel artículo de consumo.

\subsection{Ayudas}

Contribuciones, imposiciones o ayudas.- El término "ayuda" (desde 1314) tiende a utilizarse más en relación con las contribuciones sobre los productos de consumo y de primera necesidad, mientras el de "imposición"

\footnotetext{
${ }^{45}$ ARM Pergaminos no 9; Documenta, doc. 166. Pau CATEura, Sociedad y sistema fiscal del reino de Mallorca (1360-1400), ed. El Tall del Temps, Palma 2003, p. 115 y nota 209, cita un probable -y al parecer único- antecedente de 55 años antes en una "sisa porti" establecida en Mallorca el 1245 sobre mercancías introducidas en la isla por los genoveses (sobre todo textiles, alimentos, condimentos y metales). Referencias a "sisa" en el reino de Castilla, como impuesto indirecto local, sin más precisión, en María Jesús FüENTE, Finanzas y ciudades en el tránsito del siglo XV al XVI, cap. V.3, Banco de España - Servicio de Estudios de Historia Económica, 25, 1992.

${ }^{46}$ ARM Códice Sindicat de Fora XIV f. 133; Id. XV f. 151. Documento del 22 de marzo de 1300, publicado por GómEZ DE NEGRETE, Documentos, op. cit. en la nota 13.

${ }^{47}$ Antoni Pons, Constitucions y ordenacions, Palma, 1934, p. 3 doc. de 1303.

${ }^{48} \mathrm{ARM}$ pergamino $\mathrm{n}^{\circ} .20$.
} 
(desde 13-12-1337) se aplica en general sobre las transacciones mercantiles y el comercio de géneros y mercancías. Los recursos ordinarios de la universidad están constituidos íntegramente por el producto de estas "contribuciones" o "colectas" -como se las denomina también entre 1309 y 1339- que en principio se crearon para su propio mantenimiento y para la realización de obras públicas. De hecho, a partir de enero de 1300, cuando el rey autorizó por 9 años improrrogables desde el primero de marzo la recaudación de la "sise" de que acabamos de hablar, autorizaba también a la universidad a cargar sobre los "regnícole populatoribus" -denominación nueva con la que pretende subrayar la cualidad de independencia de su reinoalgunos nuevos impuestos y recargos por un tiempo limitado de años (normalmente prorrogable) con el fin de cubrir "donativos" al monarca a cambio de determinadas concesiones o de las elevadas inversiones públicas en infraestructura financiadas por aquél.

La proliferación de los impuestos indirectos -ayudas, ayudas vecinales e imposiciones- constituiría muy pronto un recurso más seguro, más general (ya que se aplica sobre las capas más extensas de la población, por mucho que la media pueda resultar de inferior renta), menos conflictivo, más permanente y sobre todo más favorable a los exentos, y es utilizado cada vez con mayor profusión. Se aplicó incluso en el caso de tener que recaudar fondos, para primar la importación de granos (como 1344 y 1347, que se impuso una "ayuda" sobre las carnes con este fin) y también sustituyó a las tallas o colectas cuando se trataba de votar tributos extraordinarios al monarca en forma de "derechos" (cenas, coronaciones y "maridaje" de infantas) o de "subsidios" ("servicis" votados en cortes, préstamos, dones...), que se fueron desencadenando en extensión a lo largo de todo el proceso de producción. Más adelante, se empezaron a aplicar también amplias cargas sobre el comercio exterior (en parte ocupado ya por el fisco real mediante las "lleudes") en forma de "generalidades" (sobre la salida de mercancías) desde las cortes de Monzón de 1363, y de "victigals" (sobre entradas y salidas) desde 1393.

I. Cuando el 1309 Jaume II autorizaba la ayuda vecinal para obras públicas de la que acabamos de hablar, nos informaba de que el tipo de imposición había sido escogido a petición de los mismos Jurados, que decían que resultaba más leve, de peso más soportable, menos "dampnosa y tediosa" y más fácil de recaudar y con menos incomodidad. La imposición de cargas indirectas sobre el consumo resultaba, de hecho, menos problemática que la colecta capitativa, que reclamaba unas investigaciones sobre los bienes, patrimonio y rentas de cada uno de de gran dificultad y segura conflictividad, y que dependía de las declaraciones juradas de los mismos interesados y de informadores nunca neutros, desinteresados ni seguros. Las ayudas se creaban, previa licencia real, por un año "prorrogable" a voluntad de los 
jurados, para obras defensivas, de conducción de aguas, vigilancia costera y otras necesidades de la ciudad y reino, y afectaban $a^{49}$

-panificación y molienda ("molige") de los granos

-reventa de vino

-despiece y venta de animales para el consumo privado de carne

II. De la época del rey Sanxo (1311-1324) conocemos dos recaudaciones: la primera por una referencia fragmentaria de un pergamino que aprovecharon para hacer las guardas de un protocolo notarial ${ }^{50}$, que se refiere a las "ayudas" sobre la carne y la molienda del grano que se recaudaban por la isla el 1 de julio de 1314, el mismo año que el rey recibía un donativo de la universidad de 10.000 libras $^{51}$; la otra es una completa disposición ${ }^{52}$ dictada 6 años después, en 1321, que autorizaba a imponer una "collecta seu contributio" sobre:

-carne

-mercaderes

-censos y agrarios

-pan y harina

por un periodo igual (del 15 de mayo de 1321 hasta el 15 de mayo de 1327), a cambio de la oferta que le hacían los jurados de 25.000 libras, que se añadirían a las 20.000 que antes le habían entregado en concepto de préstamo para las demás necesidades de la misma universidad.

III. Inmediatamente después de haber finalizado la recaudación de las anteriores imposiciones, y durante la regencia del Infante Felip (1324-1332), tío de Jaume III, el 15 de diciembre de $1328^{53}$, a fin de que los jurados y la universidad pudieran cubrir una deuda de 50.000 libras de Mallorca que habían adelantado al monarca -que las tendría que devolver dentro de los próximos cuatro años- y "otras necesidades", les autorizaron a imponer sobre todos los pobladores, privilegiados o no -pero excepto caballeros militares, clérigos y familiares reales- y a recaudar durante el período de amortización del préstamo, "ayudas, colectas o contribuciones" sobre

-la "moliga", fabricación, venta y consumo de pan y de bizcocho

-el vino elaborado o puesto a la venta y el que entrara a la ciudad o se importara

-las carnes

-la elaboración y venta o importación de las telas y tejidos de cualquier tipo para confección de vestidos.

${ }^{49}$ ARM pergamino $n^{\circ}$. 18. Para la aplicación de una talla o de un impuesto capitativo era necesaria la reălización de una evaluación o "manifest" de los bienes de cada vecino. No poseemos ningún ejemplar del siglo XIV, pero sí algunos testimonios de su mecánica. Vid. P. CATEURA, Sociedad y sistema fiscal, op. cit. p. 139.

${ }^{50}$ ARM Protocolos Notariales $\mathrm{n}^{\mathrm{o}}$ 2406, del notario Guillem Carbonell (1350-1351). El documento fue localizado por Bartolomé FONT OBRADOR, que lo cita en Historia de Llucmajor, I, Mallorca, 1972, p. 234 del tomo I.

${ }^{51}$ ARM Códice Privilegios f. 134; Códice Franquezas f. 9.

${ }^{52}$ ARM Pergaminos Rey Sanxo no 12

${ }^{53}$ ARM Pergaminos Infante Felipe $n^{\circ} 6$. 
Con eso resultaba que si del producto de las imposiciones se retribuía a quienes habían hecho el préstamo de las 50.000 libras a la universidad, después de los cuatro años, si el infante Felip había amortizado la deuda, la universidad habría tenido un ingreso neto del mismo importe, disminuido por los intereses abonados a los prestadores ${ }^{54}$.

\subsection{Proferta}

El término es mencionado desde 1358 -para contribuir a la guerra de Castilla con 300 caballeros armados-, pero es a partir de la primera asistencia en Cortes de los delegados mallorquines en Monzón en el año 1363 que se convierte en habitual el sistema de efectuar al monarca avances en forma de "proferta" o préstamo a cuenta de un servicio o "donativo" que sería recaudado por la universidad mediante el sistema -ya utilizado antes en necesidades exclusivas de la defensa insular- de recabar préstamos a interés sobre la garantía de las imposiciones que se tendrían que crear con el fin de recaudar la cantidad del donativo.

\section{LA “TAULA" DE LOS JURADOS}

En 1330 la situación de la "taula de cambi" de los jurados era de insolvencia y el Infante Felip tuvo que remitir a la isla, ante las presiones de los numerosos acreedores propios y de la universidad, a los "reformadores" Andrés Guiter y Guillem Se Grilla a fin de que arbitraran medidas urgentes ${ }^{55}$, entre las que se contaba el compromiso por parte de los jurados, aceptado por los mercaderes y los otros agentes financieros, de abonar en un año lo que debía la "taula", a cargo de lo que se pudiera recaudar de las "ayudas", pues habían descartado de entrada la imposición de una "questia" o derrama entre los habitantes. Los reformadores, en consecuencia, autorizaban a los jurados a prolongar por un año más la recaudación de las "ayudas", y ésta es la primera noticia cierta que tenemos del recurso a las imposiciones como garantía de los endeudamientos de la universidad, recurso que de inmediato se convertirá en el más frecuentemente usado.

El 1 de diciembre del año siguiente estaban recaudando también un impuesto "de la armada"56 sobre:

\footnotetext{
${ }^{54}$ Del 8 de marzo del año próximo, en efecto, nos consta un bando del lugarteniente ordenando que no se comprara vino a quien no hubiera contribuido a las ayudas, lo que se reiteró, añadiendo disposiciones relativas al uso de las medidas, el 6 de marzo de 1330. ARM Pergaminos $n^{\circ} 6$ Antoni PONS, Libro del mostassaf de Mallorca ed. CSIC, Escuela de Estudios Medievales, XI, Mallorca 1949 , p. 196 y doc no 45; ARM ÀH Escrivania de Lletres comunes 1328-30. La disposición de 6 de marzo de 1330 fue publicada en Documenta, doc. $\mathrm{n}^{\mathrm{0}} 132$.

${ }^{55}$ ARM AH 436 f. 179.

${ }^{56}$ Documenta, doc. 150 . La recaudación se destinaba a financiar las galeras que a medias entre su antecesor el rey Sancho y los jurados se pactó construir en 1315.
} 
-trigos, legumbres, frutos secos, aceite, miel, manteca y artículos parecidos que no fueran de cosecha propia;

-ventas mercantiles de ganado (incluido el cabalgar y de carga), exceptuado el de labor, así como los carniceros, en caso de que hubiera pagado ya el comprador (en forma, por lo tanto, de sisa);

-posesiones o censales que se vendieran, fueran establecidos en enfiteusis o se intercambiaran;

-importación y venta de cautivos;

-cosechas de vino, higos, fruta, lana, quesos, aceite, cáñamo, lino y similares; pastos, barbechos y bosques;

-compra-venta de casas;

-cualquier tipo de mercancía elaborada en las parroquias de la isla distintas de la ciudad, tanto de granos como de lanas, cueros de cabrío, de "anyins i moltons" (corderos y cabritos) y otros artículos cuya materia final se produjera en las parroquias mencionadas o que fuera importada a ellas, en cuyo caso abonarían también unos derechos por la carga;

-pescado fresco y salado; la reventa.

-artículos para comer o vestir vendidos al por menor o adquiridos para

Como se puede ver, se trataba ya de toda una completa gama fiscal de cargas sobre la producción y el intercambio de mercancías y de artículos de consumo.

En 1335 el rey obtuvo un tributo de "dons e cenes" por un total de $68.267^{\prime} 04$ libras $^{57}$ que seguramente dejaría agotadas las posibilidades de recaudación de los jurados, que le tuvieron que pedir -y obtuvieronautorización para duplicar aquellas "ayudas" que se recibían sobre la compraventa de mercancías y de otros productos, que parece que se iban prolongando de año en año, por mucho que su creación primera hubiera sido coyuntural; la tasa de 2 dinero por libra (un 0'83 \%) que proponían duplicar era la misma que se mantendrá todo el resto del siglo, que en muchos casos abonaban tanto el comprador como el vendedor y que representaba, por lo tanto, un 1,66 entre ambos, que ahora sería un 3 ' $32 \%$. Esta disposición la harían extensiva a Ibiza por notificación de 13-12-1337 .

En 1339 recaudaban una "colecta" para defender la isla de un pretendido ataque del rey marroquí del Garb -lo que constituyó un temor fantástico que se mantuvo a lo largo de los próximos siete años- de la que liberaron a los caballeros militares, por mucho que al cabo de dos meses insistía el monarca que privilegiados, clérigos y extranjeros tenían que contribuir a las "ayudas" impuestas para la defensa del reino ${ }^{59}$.

${ }^{57}$ ARM RP 3409 y RP 3048.

58 "BSAL" XIII, p. 143; ARM LC 1337-39 f. 9.

${ }^{59}$ ARM Códice Cofradía de Sant Jordi f. 21, documento dado en Perpiñán el 10-5-1339; Ibidem Códice Rosselló Vell, f. 176 y Rosselló Nou f. 127 v, dado en la misma ciudad el 9-71339. 
Cuándo Pere IV se posesionó por la vía directa de la isla en 1343, y mientras estaban en conflicto los caballeros con los jurados a causa del impuesto de la "molige" y de una contribución conocida como "secretam", aludió acto seguido a las numerosas cargas que había impuesto Jaume III a sus súbditos $^{60}$, y dio por nulo un "don" de 20.000 libras que habían prometido para ayudar al depuesto antecesor ${ }^{61}$. Eran solo medidas de propaganda, puesto que pronto empezará la isla a sufrir la presión fiscal más elevada de su historia. De momento, sin embargo, la absorción por parte del reino de Aragón no excluyó que se siguieran recaudando ordinariamente las imposiciones indirectas, pues una solicitud de información dirigida por el rey a su gobernador el 13 de junio de 1348 se hacía en relación con los impuestos sobre la "moliga", los tejidos y el vino.

Es en la época de aquél belicoso y fatuo monarca cuando la carga sobre la isla se desencadenó con unos dramáticos resultados que su hijo Joan I haría irreversibles cuando autorizó toda clase de arbitrariedad de los jurados en este terreno, llegando a la amnistía de los delitos en que hubieran podido incurrir en la compra-venta de censales (títulos de deuda sobre la garantía de las imposiciones) o incluso en los que "se incurriera en el futuro"62.

Concretamente, el 1349 Pere IV ya exigía 20.000 libras para la guerra de Cerdeña; el 135145.000 más, a las que tendrían que añadir 60.000 exigidas en 1353 (a liquidar en cuatro años) más un donativo de 4.000; exigió 83.000 más (de las que 10.000 se tomaban en préstamo) el 1354 y 25.000 en 1355. Es, parece, desde este momento que se inició la escalada de cargas acumuladas mientras que, a través de su enviado Gilabert de Centelles ${ }^{63}$, el rey autorizaba a la universidad de la isla a recaudar unas nuevas imposiciones hasta tanto los gastos hechos por la universidad para la guerra, más intereses, estuvieran totalmente amortizados, lo que podía interpretarse como un plazo indefinido, puesto que veinte años más tarde los jurados todavía debían parte de los préstamos que tuvieron que contraer en aquellos momentos y que la multiplicación de ayudas y de imposiciones no habían podido llegar a cubrir.

La carga sobre los productos de primera necesidad se había ya hecho permanente, en la práctica. Las imposiciones más a menudo reimpuestas y recargadas, que resultan de hecho continuadas a lo largo de todo el siglo, eran las que gravaban la molienda y la fabricación de pan, el vino, la carne y los tejidos y será sobre éstas que, en todo momento, y a falta de la posibilidad de

${ }^{60}$ ARM Códice Privilegios f. 116 v. El 24 de noviembre de 1342, desde Perpiñán, había dispuesto Jaume III que los víveres llevados a la isla por la inminente necesidad pudieran estar exentos de impuestos por decisión del Lugarteniente, previo acuerdo con los jurados, cosa que nos indica que la isla estaba ya pasando momentos económicamente difíciles y penurias alimenticias. ARM Códice Franquezas f. 96 v. La disposición de Pere IV en ARM, pergamino $\mathrm{n}^{\mathrm{o}}$.9, publicada en CATEURA, doc. $\mathrm{n}^{\mathrm{0}} .5$.

${ }^{61}$ ARM Códice Sant Pere f. 27 v. CATEURA, doc. nº 2.

${ }^{62}$ ARM Pergamino $n^{\circ} .20$ y n ${ }^{\circ} .21$; Códice Sant Pere f. 146 v.

${ }^{63}$ ARM Pergamino $n^{0} 37$. CATEURA doc $n^{\circ} .52$. 
otras fuentes o recursos, cargarán "afitons" o incrementos de los tipos tributarios ${ }^{64}$ :

-productos panificables, molienda, vino y carnes, las imponen desde 1301 y las prorrogaron hasta 1310 y quizás sucesivamente, puesto que en 1314 se perciben impuestos sobre la molienda y las carnes y los reimpondrán junto con otros impuestos, o quizás es más probable que sólo las hubieran prorrogado, pues pasados seis años las autorizaron por otros tantos desde 1321;

-molienda, vino, tejidos y carnes se cobraban de 1328 a 1333 y molienda, tejidos, vino y probablemente carne estaban cargados en tiempo de Jaume III, antes de 1343;

-productos panificables, vino, tejidos y carne sufren un recargo en 1349 y las duplicaron en 1359, incluyendo la "sisa" de la carne que tenía que haber caducado en 1352, y que comparecerá como "nuevamente impuesta" en 1374;

-la molienda la cargaron con un "afitó" otra vez en 1361;

-la sisa del vino la rebajaron en 1367 y de nuevo la incrementaron en 1371, aunque aparece como "nuevamente impuesta" en 1374;

-en 1376 los jurados autorizaron a imponer ayudas, imposiciones y generalidades sobre -entre otros- pan, vino y carne, que nos consta que ya estaban gravados.

De hecho, Bartomeu Ses Eres, que había efectuado importantes préstamos a la universidad, había comprado, según nos consta, la recaudación de los impuestos sobre las telas de la ciudad de 1356, 1357 y 1359; el del vino de la ciudad en 1356; el de la carne de la ciudad en 1357 y 1359 y el de Inca de 1358 a 1361 y otra vez en 1366; el "afitó" o recargo de la molienda de grano de la ciudad en 1357; el del pescado de la ciudad en 1359 y la "moliga", carne y tejidos de Artá en 1362. Como se ve, molienda, vino, tejidos y carne se recaudan año tras año a lo largo de toda la década, tanto en la ciudad como en las diversas villas, lo que contribuye a confirmar su virtual permanencia en la segunda mitad del siglo.

Por lo tanto, tenemos que concluir que, por mucho que se siguieran cargando, imponiendo y subastando las imposiciones por anualidades, y sin que podamos excluir alguna momentánea revocación, suspensión o sustitución de alguna imposición determinada o de algún recargo, hacia las postrimerías de la sexta década existía a ciencia cierta un contingente permanente de imposiciones, creado de forma acumulativa; al mismo tiempo, habrá que aceptar que los derivados de los granos para el consumo humano, con el vino, las carnes y los tejidos, son los productos que más a menudo y más pronto fueron gravados y cargados, hasta el punto de que su exacción resultó

\footnotetext{
${ }^{64}$ ARM LR 29 f. 219, documento dado en Barcelona el 6-10-1374, dentro del proceso a Bartomeu Ses Eres contra la Universidad. Según CATEURA esta es la primera emisión de deuda pública y la primera moratoria de deudas (por 3 años) concedida por el rey a la universidad de Mallorca. Vid. Sociedad y sistema Fiscal, op. cit. p. 164 y 174.
} 
permanente en la práctica, quizás con algún breve paréntesis o reducción momentánea.

Después de la imposición de 1331, sin embargo, hasta 1374 no tenemos noticias de ninguna imposición específica sobre el aceite, el tercero de los productos agrícolas básicos de la isla.

Lo cierto es que en 1373 Berenguer de Abella, portador de un plan de reforma elaborado en la corte aragonesa y hombre de confianza del monarca, indicaba que existían 38 imposiciones que creía que se podrían reducir a las básicas en molienda, carnes y vino. La relación detallada de los productos, actividades o contingencias que estaban gravados entonces, según ha aportado recientemente el profesor Cateura, se mantenía paralela entre 1362 y 1390, de acuerdo con dos relaciones conocidas, pero quizás con intermitencias y oscilaciones, por lo que no podemos saber con certeza cuales eran los productos que estaban gravados en aquel preciso instante; después de 1373 las noticias más cercanas que poseemos son las referencias a una modificación efectuada en 1386 a los respectivos capítulos de 12 de los 29 impuestos ${ }^{65}$ subastados en 1390, que abarcaban la más variada y completa gama de artículos y transacciones ${ }^{66}$.

\section{LAS CARGAS FISCALES}

A) Las cargas de la universidad y sus diferentes fuentes de ingreso

Las necesidades de tipo burocrático y funcional de la universidad, que no tenía patrimonio propio que la dotara de rentas para su mantenimiento, se mantenían desde su origen, como hemos visto, con tallas y recaudaciones episódicas para cada necesidad determinada, tanto si era el control de los abastecimientos (importaciones de grano o de subsistencias), como si se trataba del pago de salarios, de compensaciones a delegados o enviados del monarca (no sus salarios, que los abonaba el Real Patrimonio), el mantenimiento de servicios públicos (caminos, puentes, cursos de agua, oficinas y oficiales públicos...) y la reparación y sostén de unidades defensivas (construcción y mantenimiento de galeras, de fortificaciones, provisión de fuerzas armadas y de vigilancia, etc..)

El segundo capítulo destacado de los gastos, y el más importante por lo menos en la segunda mitad del siglo XIV, era el de las transferencias de capital al monarca y las contribuciones ofrecidas para expediciones y empresas bélicas solicitadas o exigidas por la corona, o acordadas con ella.

Ambos capítulos, pues, constituyen la deuda de la universidad y la llevan a la creación indiscriminada de imposiciones indirectas, sin que, por

${ }^{65} \mathrm{ARM}$ Códice 29, totalmente trascrito por el autor.

${ }^{66} \mathrm{La}$ relación, prácticamente exhaustiva, de las mercancías, productos, subsistencias y transacciones gravadas en el apéndice de LOPEZ BONET, Josep Fc. Comunidad y corona op. cit. La relación de 1362 localizada por el Prof. CATEURA en el ADM figura en Sociedad y sistema fiscal op. cit. pp. 116-117. 
eso, deje de acudir a la talla o colecta directa en casos determinados (gastos de mantenimiento, devolución de préstamos, provisión de trigo, necesidades de extrema urgencia, etc...), de carácter excepcional ${ }^{67}$.

\section{B) La transferencia impositiva}

La producción viene gravada en su origen por tributos y cargas fiscales ligadas con los derechos de regalía, de la iglesia y del dominio (diezmos y tascas) pero, además, soporta en la transformación y el intercambio -de manera que recaen sobre los precios al consumo, el gasto familiar y las fuerzas productivas- las cargas impositivas de las que la organización comunal insular extraerá los recursos para obtener su mantenimiento y el de las contingencias extraordinarias, pero también para retribuir el capital aceptado por adelantado, que lo será a préstamo o mediante la venta de títulos sobre la garantía de los impuestos y "ajudes", mediante el ofrecimiento de rentabilidad a los financieros censualistas que adelantan el contingente a reponer y que, en general, no son contribuyentes pues pertenecen a otros reinos o, si son insulares, al sector acomodado y en parte -sólo en parteexento (caballeros, privilegiados militares, titulares de dominios y eclesiásti$\cos )$

Desde 1355 podemos definir, pues, dos niveles de tributación que inciden sobre un mismo producto y sobre los grupos productivos de la sociedad, más allá del arrendamiento (en el caso de la agricultura) de las instalaciones productivas y de su secuela de laudemios, tanteos, prestaciones diversas, etc... institución

-las cargas ordinarias (directas e indirectas) que mantienen la

-y las extraordinarias indirectas, de las que se extraen las sumas para los subsidios o ayudas al monarca o para las pensiones precisas para retribuir los créditos contraídos para hacer efectivos servicios o dones.

Éstas constituyen, en el último caso, la fuente y expresión recaudatoria última que alimenta los tributos extraordinarios directos que, en términos de recursos, no consisten más que en una mera distinción taxonómica de las diferentes fases del proceso de transferencia de caudales privados en manos de la corona.

No es de extrañar que ello distinga, dentro de la sociedad oficialmente estamentalizada, confrontaciones de clases (reflejadas a nivel impositivo entre exentos / acreedores y contribuyentes / productores, con cuántas combinacio-

\footnotetext{
${ }^{67}$ Según FonT I RIUS, La administración financiera, op . cit. p. 621, la imposición de tallas no requeria autorización real. Véase Alvaro SANTAMARIA, Mallorca en la primera mitad del siglo XV, "IV CHCA", Palma de Mallorca, 1955. También BAUZA, op. cit. parrafo 78. El tema de las tallas ha sido tratado sobre todo por María BARCELÓ Y CRESPÍ, La ciutat de Mallorca en el trànsit a la modernitat, tesis doctoral inédita; también en Anotacions sobre l'interés de les talles com repertori antroponímic, en "Butlletí d'Onomàstica", VII Coloque, Mallorca, 1982; el estudio comparativo de las tallas de 1478 y 1512 es la base de los trabajos de la misma autora Els misserables de la ciutat de Mallorca a la baixa edat mitjana, publicado en el "BSAL" $n^{\circ}$ "41, 1985. Vid. también Francisco RIERA VAYREDA, Las tallas: aportación al estudio de la fiscalidad en Mallorca, "BSAL", 41 (1985).
} 
nes posibles se quiera) entre las capas de población relacionadas directamente con la producción, transformación y distribución de las subsistencias y los artículos de consumo y las clases privilegiadas que aplican el capital acumulado sobre la base de los excedentes a la obtención de réditos extraídos, también, del sobreproducto de las primeras (pues las pensiones que pagan los jurados a los censualistas se extraen también de cargas indirectas sobre el consumo), a través de la renta perpetua o vitalicia constituida por las pensiones de los censales o títulos de deuda pública.

\section{LA ACTUACIÓN Y LA ESTRATEGIA DE LOS JURADOS}

De los jurados de Mallorca (comité ejecutivo del Consejo General) no nos queda apenas documentación relevante o completa anterior a 1410. Por eso la reconstrucción de su estrategia funcional se tendrá que hacer sobre la base de los indicios que nos ofrece, siempre parcial, la correspondencia de la Cancillería real, mucho más completamente conservada, sobre todo en aquello que alcanza al periodo correspondiente a la segunda mitad del siglo XIV.

\subsection{El abastecimiento de la isla}

Los jurados son responsables de obtener suministros para la isla en los momentos de carestía, que menudean ${ }^{68} \mathrm{Y}$ también menudean las acusaciones de los foráneos -pero también las de los privilegiados- respeto a la nula transparencia y al escaso control aparente sobre los comités que evaluaban las necesidades de importación de trigo y con qué premio las tenían que favorecer y, sobre todo, a quién se tenía que confiar el encargo o a quién tenían que dar la capitanía de la armada -si la ponían los jurados- o a quien tenían que beneficiar con la compra de los excedentes ya importados. La connivencia con mercaderes que se habían ofrecido a vender trigo de importación era, sin lugar a dudas, una tentación demasiado fuerte, como lo era también la de invertir en participaciones de la nave o armada fletada con fondos públicos: la documentación de los siglos sucesivos a menudo nos dará muestras de todo ello.

${ }^{68} \mathrm{Al}$ respecto nos son conocidas numerosas y reiteradas disposiciones. Por ejemplo: el 3-71345 obligaron a los generosos y privilegiados a participar en las contribuciones para recaudar dinero para importar granos; de 1-4-1348 al 1-4-1351 se prorrogaron las ayudas sobre la carne para poder subvencionar las importaciones de grano y otros comestibles, en prevención de la defensa del reino dado que se reconoce que la Universidad de Mallorca no tiene rentas propias de las que poder hacer ahorros para la eventualidad de que la isla quedara aislada o asediadá; el mes de junio de 1374 se dictan disposiciones, hacen propuestas y se adoptan provisiones para el abastecimiento de trigo; el 26-4-1375 Pere IV ordena que la universidad organice armadas para capturar cualquier nave cargada de granos que se pusiera a su alcance; el 19-3-1385 el rey reconoce que no se pueden extraer más caudales de la isla "per los grans carrrecs del temps passat e en special per les ajudes e altres messions que ha haude a dar e fer per provisions de blat en los anys passats e present". 
También en relación con el abastecimiento de la isla conocemos ${ }^{69}$ la compra por parte de los propios jurados, en 1383 y por un periodo de tres años, del ganado que pudieran recaudar los diezmeros reales y los del obispo, con el fin de proceder a arrendar por cuenta suya el despiece y la venta de carne a través de una "taula asegurada", es a decir: regida por un cambiador que tendría que reclamar garantías a los compradores (recaudadores) del derecho de la carne, a quienes ofrecerían la seguridad de la exclusiva, bajo la protección del poder público.

La convivencia culpable entre los jurados y los diversos administradores o beneficiarios de caudales públicos se nos revelaba ya en el plan de reforma de Gilabert de Centelles de 1359, que insistía que los jurados no podrían, en lo sucesivo, acordar la concesión de ninguna cantidad sin el consentimiento de todos o de la mayoría de los consejeros de la ciudad y de la parte foránea, ni podrían conceder adelantos o créditos a ningún comprador de ayudas, de imposiciones o de otros derechos de la universidad si no era por consenso de todos -o de la mayoría- de los consejeros de la ciudad y de las villas.

\subsection{La política fiscal}

Pero el aspecto que interesa más a este trabajo es el de la mecánica impositiva y la política fiscal de los jurados.

La votación de imposiciones a menudo se hacía bajo la presión de las necesidades perentorias de mantenimiento del Consejo y de su estructura administrativa, además de la que ejercía el monarca, que a menudo exigía con urgencia dones y subsidios. Todo ello estaba agravado por un elevado nivel de fraude y de corrupción que empezaba por los mismos jurados, a menudo amparados por la tolerancia real, siempre bajo la imposibilidad de cuadrar rigurosamente unas cuentas cada vez más incompletas y desordenadas. Tenemos que añadir que las tensiones internas del organismo entre los partidos, los foráneos y los ciudadanos, o entre el lugarteniente, el alcalde y el Consejo, a menudo obstaculizaban cualquier posibilidad de acuerdo ante la necesidad de un control riguroso.

La urgente necesidad se apacigua con el recurso al préstamo, sobre la garantía de las imposiciones. Otro sistema utilizado a partir de 1366 fue la emisión de títulos perpetuos o vitalicios a determinado interés, en general ligados a la imposición de ayudas concretas, tanto de las ya existentes como de las inventadas de nuevo ${ }^{70}$.

\footnotetext{
${ }^{69} \mathrm{ARM} 1292 \mathrm{~s} / \mathrm{f}$.

${ }^{70}$ En 1360 aparece la talla de las "semanas"; en 1363 el derecho del segell y las diversas "generalidades"; en 1363 la carga sobre los tejidos extranjeros que entran a la isla para "vestir y cortar", sal y pescados (carga de la que no teníamos noticia desde 1331); el 20-8-1384 la carga sobre los esclavos mayores de 10 años y sobre poseedores de bienes superiores a 200 libras, y en 1392 los "victigals" del mar y del aceite.
} 


\subsection{Los exentos}

Las necesidades ordinarias parecen corresponder a tallas periódicas $\mathrm{y}$, de entrada, a los llamados "subsidios o colectas vecinales". Mientras éstos se aplican por el sistema de capitación no se producen tensiones más allá de las habituales, puesto que los caballeros y los clérigos eran considerados tradicionalmente exentos de ellas. Pero cuando se trata de imposiciones sobre el consumo o para necesidades consideradas vitales, la discrepancia con los exentos surge de inmediato.

Los exentos no lo eran en obras de defensa y otras para bien del reino, como ya hemos visto en el primer capítulo, pero tampoco en los subsidios vecinales por lo que poseyeran en la porción real o por las posesiones que hubieran adquirido más allá de su patrimonio original, ni en los impuestos sobre las transacciones cuando lo adquirido era para el consumo doméstico, por mucho que continuamente lo invoquen y a veces lo alcancen.

\subsection{La resistencia a las exigencias del monarca}

$\mathrm{Al}$ frente contra los defraudadores, los eclesiásticos y los exentos, se añade el frente contra las exigencias reales, a veces tan imperiosas que, por mucho que los monarcas reiterarán que no se impondrían ayudas sin su autorización y la del gobernador o lugarteniente, no por eso dejaron de legitimar "a posteriori" contribuciones impuestas por los jurados en determinados momentos, empujados por la urgencia vital. Tampoco los jurados dejaban de aprovechar los momentos psicológicos de peligro para el reino en provecho propio ya que, por ejemplo, y entre otros muchas ocasiones, el 15 de septiembre de 1366 los privilegiados alegaban irregularidades de los jurados ante Pauquet de Bellcastell, diciendo que aquellos habían desviado fondos destinados a los donativos al monarca para aplicarlos a otras necesidades.

El frente ante del monarca consiste en la negociación de las prestaciones recíprocas. El sistema es el habitual en las Cortes, pero el reino de Mallorca no tiene legítimamente representación ni Cortes propias ${ }^{71}$. De

${ }^{71}$ El reino de Mallorca, obligado a declararse en feudo de la corona aragonesa por Pere el Gran el 20-1-1279 (convento de frailes predicadores de Perpiñán), desposeído de su monarca poco después (1285), forzado a reconocerse vasallo del rey de Aragón en 1296 -lo que tuvo que confirmar Jaime II en su reincorporación el 29-6-1298 (excepto para Montpeller), y tuvo que suscribir su sucesor Sanxo (28-6-1321 Convento de frailes Predicadores de Gerona) y en 1329 su último monarca Jaume III, definitivamente expulsado del reino por su suegro Pere IV en 1343 , precisamente bajo el pretexto de haber incumplido la fidelidad y los pactos- no tuvo nunca cortes propias, ni representación en las generales o en las de cualquiera de los reinos de la Corona de Aragón (Cataluña, Aragón y Valencia) De la obligación de que su monarca asistiera a las de Catâluña, que iba anexa a los pactos feudales, fue expresamente eximido el rey en Sancho a título particular y para agradecerle su aportación a la armada para la expedición a Corcega y a Cerdeña. En todo el siglo XIV a los mallorquines solo se les obligó tres veces a remitir diputados a las Cortes, a fin de que se obligaran a participar en los donativos al monarca, dentro del brazo de las ciudades reales. En 1363 empieza con lạs cortes de Monzón a las que asiste una representación de Mallorca, por primera vez desde la incorporación en la corona aragonesa de 1349; el 5 de marzo las cortes votarán una ayuda al rey, con efectos de primero de abril:

-le ofrecen 130.000 libras de Barcelona, que incluían un adelanto de 60.000 florines (33.000 libras 
de Barcelona) que le habían hecho ya conjuntamente los diputados de Cataluña y Mallorca; -de las 130.000 pagarían 65.000 (88.400 libras de Mallorca) las islas de Menorca e Ibiza (sin duda junto con otros representados) y la otra mitad Cataluña y Mallorca;

-a cambio, se creaba el "dret del sagell" o de los "draps" (que con el tiempo se llegaría a conocer también como "de la bolla") que consistía en 12 dineros por libra (un 5\%) sobre el valor de las telas que se fabricaran en el reino, más 3 dineros (en Mallorca 4) por pieza, para retribuir a los encargados del sello de plomo que se tendría que imponer en todas las piezas de tela que se fabricaran o que entraran en Cataluña o en las istas y también al notario que tendría que llevar el registro; los que vendieran telas abonarían también 12 dineros por libra del precio obtenido y no podrían entrar en los reinos ningún tipo de tejidos o telas extranjeras de lana o estambre, y se concluía que no se cargaría ningun otro impuesto sobre los textiles;

-impondrian una carga de 2 sueldos por libra (un $10 \%$ ) sobre toda la lana que saldría de los reinos (con la excepción de Córcega y Cerdeña), que estaría vigente solo mientras durara la guerra de Castilla;

-además, imponían "generalidades" sobre numerosas mercancías que salieran de los dominios de Pere IV: 4 sueldos por libra (un $20 \%$ ) el azafrán, granos y ganado; 3 sueldos (15\%) el hierro, jabón, resina o pescado, alquitrán, arroz, "alquena", naves y madera para fabricar naves; 2 sueldos (10\%) el aceite, la grana, miel, plomo y "cofoll", cáñamo, lino y estopa, cueros, "roudor, sumach, tany, sal de compas," higos, pasas, frutas y legumbres, esparto, mimbre, palma, pescado fresco salado, quesos y mantecas, madera y vino; 1 sueldo $(5 \%)$ sobre cera, caballos y otros équidos como asnos, mulos y mulas;

-cada cofradía -que no se podrían disolver en tanto durara la guerra- de cristianos como de judíos o sarracenos, pagaría 4 florines cada año

-de todo lo que se recaudara pagarían, además del "don", los 61.500 florines que el rey había tomado de Cataluña y Mallorca en concepto de préstamo para pagar 2 meses de sueldo a las fuerzas de Enrique de Trastámara y los franceses:

-las 130.000 libras eran anuales, desde el primero de abril siguiente hasta el primero de noviembre de 1365 , en plazos trimestrales, es decir, por 2 años y 7 meses, y harían un total, por lo tanto, de 335.833' 3 libras de Barcelona (equivalentes a 456.733 de Mallorca), que se tendrian que repartir entre Menorca, Ibiza y los brazos de eclesiásticos, ricos hombres y caballeros, por una parte, y la otra mitad la abonaría el brazo de las villas y lugares reales, Mallorca y un grupo de otras personas que pagaban aparte, de acuerdo con la distribución que habían hecho en las Cortes de Cervera;

-la ayuda la destinarían exclusivamente a la defensa de Cataluña y Mallorca y el rey no podría imponer ninguna otra mientras se estuviera haciendo su recaudación;

-nadie estaria exento de cotizar -a tanto por fuego u hogar-, ni tal siquiera "los moros":

-del "don" se pagarían también 40.000 sueldos que el rey había recibido de un préstamo de Gilabert de Centelles.

Tres días más tarde continuaron las Cortes con el "don" de Aragón, en las que ofrecieron, entre todos los reinos (Aragón, Valencia, Mallorca y Principado de Ćataluña) 250.000 libras de Barcelona por año durante dos años, a contar desde la próxima fiesta de Todos los Santos (1-111363 a 1-11-1365), hasta totalizar 500.000 libras (de las que Aragón tenía que aportar 60.000 por año) y que no podrían ser recaudadas mediante imposiciones. (ARM pergamino $n^{0}$. 20) En aquellas Cortes fue cuando Pere IV dictó el privilegio por el cual concedia plena licencia a todos los municipios de sus reinos para imponer, recoger y recibir imposiciones y "sizes" sobre cualquiera cosas y mercancías, obligando a cualquier persona, y añadió que las reclamaciones y litigios surgidos a raíz de las imposiciones establecidas correspondieran a los mismos magistrados municipales, sin intromisión de los oficiales reales, privilegio que confirmó su hijo Joan I en Monzón el 1400.

En octubre de 1375, desde Barcelona, el rey convocó a Cortes Generales con la presencia de aragoneses, valencianos, mallorquines, catalanes y roselloneses, para el próximo 25 de noviembre en Monzón. Las Cortes, de hecho, no se abrieron hasta el mes de marzo de 1376, para tratar principalmente de los proyectos de invasión del duque de Anjou, que se decía que había contratado 4000 lanzas y más de 40 galeras. El rey solicitaba, por primera vez, a las Cortes una ayuda exclusivamente monetaria, para contratar a 4000 lanceros que mandaría el Infante Joan para defender el Rossellón. Los delegados se alborotaron: alegaban que en las guerras anteriores habían servido al rey, principalmente, con sus personas y que, aparte de cantidades "excepcionalmente" concedidas, la mayor parte de la carga financiera había ido sobre las aljamas de moros y judíos. Después de las tensiones habituales, el monarca obtuvo, al fin, un compromiso de ayuda de 325.000 libras de Barcelona, de las que a Mallorca le correspondia abonar 19.600 (26.725 libras de Mallorca); Menorca e Ibiza fueron esta vez agregadas a Cataluña, que comprometió 158.500 libras. Del caudal que tenía que aportar Mallorca detraerían un donativo de 3.000 florines $(2.250$ libras) que habían destinado en parte a acabar las 6 galeras que habían empezado a construir en los astilleros. El total comprometido, pues, era de 24.475 libras mallorquinas.

El donativo no se hizo sin las habituales contrapartidas: aunque el rey ponía la condición de que las lanas que no fueran de la tierra, y especialmente las de Venecia y Pisa, estuvieran exentas de derechos, concedía al "consejo" y a la universidad la facultad de poder obtener por su cuenta cantidades para sus necesidades; unos días después dió su autorización a los jurados y a los síndicos, tanto de la ciudad como de las villas, para vender censales "muertos" y "violarios", no 
manera sistemática, los jurados de la isla exigen negociación aparte hasta que, en 1363, el monarca les obligó a incorporarse a las Cortes de Monzón ${ }^{72}$, dentro del brazo de las ciudades y las villas reales, experiencia que repitieron (con algunas diferencias) en 1376 y a en las Cortes de Fraga de 1384.

Excepto en estos casos, no se reconoce la obligación de someterse por analogía a lo que hubieran votado las Cortes Generales o las de Barcelona, pues a nadie se le ocurre siquiera creerles obligados a las Cortes de Aragón o de Valencia. Caso típico son los acontecimientos de 1366, cuando los jurados alegaron que no se creían sometidos a las determinaciones de las Cortes de Barcelona, en las que no habían participado, aunque aquéllas

obstante cuạlquier prohibición anterior, y autorizaba también a los jurados a imponer "de nuevo" y por el tiempo que hiciera falta ayudas, imposiciones y generalidades sobre pan, vino, mercancías, carne u otros artículos cualquiera, y también a incrementar, si así lo querian, las que pudieran ya existir, fuera para hacer frente a la oferta que le habían hecho en las Cortes de Monzón o fuera para responder de las pensiones de los censales muertos y violarios que para ello tendrían que poner en circulación de nuevo, y concedía una prórroga de dos años a la universidad de la isla para satisfacer todas sus deudas. Para hacer frente al donativo los jurados se verían obligados a consignar 8.impuestos al pago de las pensiones de los censales muertos y violarios que tuvieron que emitir, dejando reservado el fruto de su recaudación exclusivamente a tal finalidad. El rey estaba preocupado para saber si podía pedir con urgencia en cualquier momento las cantidades de que estaba a menudo necesitado e hizo reunir los diputados permanentes de las Cortes y les encargó un estudio sobre la marcha de la recaudación y, de las "generalidades" impuestas para satisfacerla; de acuerdo con las informaciones que envió al monarca el diputado de la isla Ombert des Fonollar, Pere llegaba a la conclusión que "tan poques son les generalitats que vosaltres hauets imposades per leuar e pagar la part que us toca... que no bastarien per res a la dita part vostra dins lo temps que pagar se deu, de que sou dignes de fort greu reprensió, car posats-ne nostres afers en tan gran peril". En consecuencia, el rey no se priva de ordenar ansiosamente que impongan tantas "generalidades" como sea preciso y que permitan a los Diputados recaudarlas y administrarlas para hacer frente al donativo comprometido, mientras los amenaza airado que "part la inobediencia de que us puniriem, nos en tornariem sobre vosaltres". A principios de 1383 el rey está en Tortosa para preparar a una armada, mientras la isla de Mallorca está a punto de verse de nuevo arrasada por una epidemia -que se añadiría a la nómina de desgracias- que afectará a todos los territorios de la Corona de Aragón. En junio se abrieron las Cortes en Monzón, que se tuvieron que trasladar a Tamarit y de alli en Fraga, en febrero de 1384 , perseguidas por la peste. Los delegados mallorquines asedian al monarca sin alcanzar que rehiciera el sistema de elección y de constitución del organismo cameral de la isla que había establecido últimamente, pero obtuvieron que la cantidad que le correspondiera abonar a la isla a proporción de los 60.000 florines que habían ofrecido Aragón, Cataluña y Valencia en las Cortes - a regañadientes y a costa de haber defraudado al rey- la podrían sacar los jurados de las ayudas o generalidades que ya habían impuesto o de la venta de censales, siempre que no se crearan nuevos "vectigals" ni se aumentaran los "ya impuestos". El importe de este subsidio, según el profesor Cateura, habría subido a 10.000 florines (7.500 o 7.000 libras de Mallorca, según se cotizaran en 15 o en 14 sueldos), sin que nos conste que se llegara a abonar, dado el caso de que las Cortes fueron muy discutidas y conflictivas y se prorrogaron -ya en tiempo del rey Joancuando le ofrecieron 130.000 libras de Barcelona, que incluian un adelanto de 6.000 florines (33.000 libras de Barcelona) que le habian hechjo ya conjuntamente los diputados de Cataluña y Mallorca, puesto que las Cortes acabaron por ser suspendidas en marzo de 1389, haciendo que el rey tuviera que negociar sistemáticamente por separado, lo que a menudo hace con tal tozudez que a los delegados mallorquines les costó incluso ser encarcelados, como les pasó en 1366, hasta tanto que pudieran ofrecer máximas garantías de que pondrían todo su empeño con el fin de obtener para la guerra de Castilla un subsidio de 120.000 flọines (90.000 libras de Mallorca), que al fin lo abonaron en dos plazos anuales, de manera graciosa y sin que significara el reconocimienmto de ningún compromiso anterior contraído por ellos o por lass Cortes, después de una transacción en 30 capítulos que tuvieron que firmar el rey, su esposa y el infante Joan, heredero y futuro monarca. En el acuerdo se entendían incluidas en la cifra las participaciones de Menorca e Ibiza, de los clérigos y de la posesiones de privilegiados que residieran fuera de la isla y alguna deudas contraídas anteriormente.

${ }^{72}$ Vid. Josep F. LóPEz Bonet, Comunidad y corona, op. cit., p. 64. Según Pau CATEURA Sociedad y sistema fiscal op. cit. p. 190, es desde aquel momento que "a la fiscalidad real instrumentada a través de los municipios, se suma la fiscalidad del Estado, instrumentada por las Cortes". 
hubieran condicionado su ayuda a Pere IV a que los mallorquines colaboraran. Negociaron por separado y obtuvieron importantes concesiones a cambio ${ }^{73}$.

Modelo de las negociaciones fuera de las Cortes es, por ejemplo, el pacto de Poblet de $1360^{74}$, cuando alcanzaron a poder poner como condición para la aportación de Mallorca que se obligara a contribuir también a los eclesiásticos y que se incluyera en el subsidio lo asignado a Menorca e Ibiza, solicitud frecuente y reiterada puesto que, por la confirmación de las Franquezas que había hecho el rey Sanxo en 1311, Mallorca estaba obligada a acudir en socorro de aquellas islas, que al fin alcanzaron a contribuir aparte (y lo hicieron junto con Cataluña) en las Cortes de Monzón de 1376.

Dos años después en los 63 capítulos del pacto de Lérida de $1379^{75}$, los jurados de la isla obtuvieron:

-no tener que contribuir si no lo hacían los demás reinos;

-una reducción de la cantidad a aportar, incluyendo restos pendientes de abono;

-la autorización para imponer recargos sobre las mercancías en tránsito en la isla, con el fin de compensar la salida de moneda de Mallorca (tal como había ocurrido en casos anteriores, con motivo de la adquisición de deuda pública por parte de los no residentes);

-la promesa de que no les solicitarían otro don en los siguientes tres años, ni les exigirían los títulos de las posesiones (cabrevar) -que era una amenaza real que a menudo atemorizaba y abrumaba a los negociadores- por espacio de dos años;

-sobreseimiento de deudas;

-la participación en los beneficios de la expedición a Cerdeña, que se tendría que hacer antes de 16 meses; realengo.

-y la contribución de los eclesiásticos que tuvieran bienes en el

El rey les autorizaba a incrementar impuestos, pero no a no emitir censales ni violarios (títulos de deuda pública), aunque al cabo de pocos días les prorrogaron por 6 años más el plazo que les había concedido para redimirlos.

\subsection{La captación de capitales}

Los capitales necesarios para el mantenimiento de la organización comunal y para las obras públicas, se obtenían:

\footnotetext{
${ }^{73}$ Ibídem p. 81 y 82. Los jurados llegarían a aceptar que la isla contribuyera en 120.000 florines, a pagar en dos años, de manera graciosa y sin que significara el reconocimiento de ningún compromiso anterior contraído por ellos, la votacion de imposiciones o por las Cortes, después de una transacción en 30 capítulos que tuvieron que firmar el rey, sụ esposa y el ịnfante Joan, heredero y futuro monarca; en el acuerdo se entendian incluidas en la cifra las participaciónes de Menorca e Ibiza, de los clérigos y de las posesiones de privilegiados que residieran fuera de la isla y algunas deudas contraídas anteriormente.

${ }^{74}$ Ibídem p. 64.

${ }^{75}$ Ibídem p. 114.
} 
-en principio por el ingreso en la "taula" de los jurados de las cantidades que liquidaban mensualmente quienes habían comprado la recaudación de tallas o de imposiciones y también de los préstamos o depósitos debidamente escriturados y reconocidos ("a scrita de taula"), mediante el compromiso de la devolución en cierto plazo por un cierto valor y a un cierto tipo de cambio, en determinado tipo de moneda, susceptibles de ser endosado ("a dita de taula") a terceros;

-ya desde 1330 las "ayudas" a imponer son utilizadas como garantía de préstamos o de moratorias de deudas; lo más frecuente será garantizar las emisiones de deuda pública con las imposiciones, ligando los importes estimados- de la recaudación con el volumen de las pensiones contraídas.

-a partir de cierto momento (quizás anterior a la fecha conocida de $1366^{76}$ ) los empréstitos se obtienen a través del sistema -frecuente en las transacciones privadas de crédito- de la "venta" de censales (títulos por un determinado valor nominal) que daban derecho a una determinada renta o pensión (bien vitalicia, bien perpetua) a un determinado tipo (for) generalmente entre un 8 y un $10 \%$, sin rescate de capital, a no ser que la venta se hubiera hecho por "carta de gracia". En este último caso, el capital podría ser redimido dentro de determinado plazo por el valor inicial y, por lo tanto, más que como deuda pública consolidada, funcionaba como un préstamo o depósito a plazo y con tipos de interés a menudo más favorables.

\subsection{Los $\operatorname{censos}^{77}$}

Las fortunas, dotes, donaciones y legados muy pronto se evaluarán en censos (es decir, en rentas fijas y periódicas), que se negociarán en operaciones de compra-venta que constituyen, en realidad, operaciones de crédito entrega de un capital cierto ( el préstamo o el precio de la venda) a cambio de una determinada renta- bajo forma de "censales" en que el comprador del censo sustituye al anterior titular en la percepción de la renta.

\footnotetext{
${ }^{76}$ En Barcelona esta modalidad se consolidó a partir de 1340 y llegó a ser corriente unos 20 años más tarde. Vid. Jaime VICENS VIVES, Historia económica de España, Barcelona, $1975 \mathrm{p}$. 218. También J.M. FONT I RIUS, op. cit. p. 625. Pau CATEURA, en Sociedad y sistema op. cit. p. 170 , menciona la fecha de 1368 en que el monarca autorizaba la emisión de deuda pública hasta los 360.000 sueldos en moneda de Barcelona, para amortizar los préstamos y intereses de 2 sueldos por libra (10\%) que gravaban sobre la universidad.

${ }^{77}$ En las transacciones privadas, que el capital consistía, en general, en el derecho de explotación de un bien raíz o inmueble, la pensión, "cens" o "censal" podía ser pagada en especie (generalmente en grano) y "cens" o "censal" son los términos utilizados también para cualquier tipo de renta periodica (generalmente anual) de un bien. El "censo" es, por lo tanto, casi siempre por un plazo indefinido, y no contempla la posibilidad de amortización o rescate del capital, ya que lo que se transfiere es la explotación del bien o finca que lo constituye, derecho de uso que puede ser transmitido con la obligación anexa de abonar el censo, sin afectar a la titularidad y a los derechos del titular de la finca o bien.

El término "censal", por otro lạdo, parece haberse orientado más bien a la obligación, bajo ciertas garantías, de abonar una pensión a cambio de un capital recibido, y podía tener un plazo final o podían haber estipulado la posibilidad de remisión ("luició") mediante la devolución del capital, en determinadas condiciones. Los dos tipos "principales de estos "censales" son los "morts" y los "violaris", es decir, a perpetuidad o vitalicios. No siempre, sin embargo, los dos términos se distinguen claramente en la doçumentación, , por lo que en Cataluña parece que a la otra modaliodad de censos los denominaron "vius".
} 
Pronto se empezaron a establecer sistemas de transferencias de "censos" que serían enajenados como renta a cambio de empréstitos o a consecuencia de endeudamientos, y aparecieron las modalidades de: -censo consignativo (que se transfería a un determinado acreedor la percepción o el derecho sobre alguna renta periódica fija -censo- de un bien) -censo reservativo (que recargaba sobre algún bien o finca, en el momento de transmitirla el censitario, con independencia de los censos anteriores perpetuos debidos al señor del dominio útil o censualista)

Los censos, por lo tanto, empezaron a circular como títulos de crédito y pronto se convertirían en la modalidad preferente de ahorro y de colocación de capitales.

\subsection{Los "censales" de la universidad}

El factor innovador de la política fiscal, en cuanto a la práctica impositiva en el siglo XIV, tal como nos lo aporta la documentación, es la emisión de censales "muertos" (títulos de deuda perpetuos y transmisibles) y de "violarios" (vitalicios), a determinado interés, en general garantizados por la creación de imposiciones (o ayudas) concretas, -tanto de las ya existentes como de las inventadas denuevo- de los que la primera noticia nos aparece el once de noviembre de $1366^{78}$ El rey autorizaba la emisión de censales y violarios una vez que había recibido la primera entrega de 20.000 florines de las 90.000 libras de Mallorca comprometidas por la isla a Pere IV para la guerra con Castilla, a pesar del compromiso en contra adoptado en las Cortes de Cataluña, dado que se reconocía oportunamente que Mallorca no estaba vinculada al mismo.

El término "censal" será desde entonces prácticamente sinónimo de "deuda pública" y los censales constituyen la expresión formal de aquella, puesto que la amortización de los mismos dependía de las recaudaciones fiscales -con lo que se transfería a manos de los censalistas privados el fruto de las cargas tributarias- aunque sin que las oscilaciones de estas últimas afectaran al valor de cambio de los títulos de deuda, lo que obligaba a los jurados a frecuentes impagos, re-negociaciones y moratorias en los años en que, por la causa que fuera, las imposiciones y ayudas recaudaran menos de los esperado, e incluso a la creación de nuevos subsidios y a la re-negociación continua del adeudo.

El hecho de que la universidad de la ciudad y reino pusiera en circulación títulos negociables no constituye, en este caso, incremento

${ }^{78} \mathrm{P}$. CATEURA, doc. $\mathrm{n}^{\circ}$. 110. El rey autorizaba la emisión de censales y violarios una vez que había recibido la primera entrega de 20.000 florines, a pesar del compromiso en contra adoptado en las Cortes de Cataluña, puesto que se reconocía que Mallorca no estaba vinculada al mismo. Según FONT I RIUS, La administración financiera op. cit., pp. 616-617, en Barcelona hasta 1390 no podía decidir el municipio una emisión de renta. Véase también el excelente estudio de Jesús LALINDE, La base ideologica del sistema impositivo aragonés histórico, en "Historia de la Hacienda Española", Instituto de Estudios Fiscales, Madrid, 1982. En lo que se refiere a Cataluña, véase también Jean BROUSSOLLE, Las impositions municipales de Barcelone de 1328 à 1462, "Estudios de Historia Moderna", V, Barcelona, 1955. 
significativo de la masa de capital en circulación en la isla, ya que no existe una convertibilidad inmediata -por ausencia de reservas- y que, puesto que su remisión o retirada del mercado es dependiente directa de la recaudación de imposiciones sobre consumidores y productores, en el caso de que no hubiera incremento de la producción, y por lo tanto de la recaudación, repercutía sólo en una reducción de las pensiones. Es decir, puesto que la amortización de los "censales" dependía de las recaudaciones fiscales -con lo que se transfería a manos de los censualistas privados el fruto de las cargas tributarias- las oscilaciones de éstas últimas afectarían en el mismo sentido al valor de cambio de los títulos de deuda.

Se puede considerar, además, que el hecho de que fuera exportado el capital o consumido por monarca y ser la demanda de censales -a partir de determinado momento- principalmente exterior (en general por parte de los inversores catalanes), su emisión constituye, de hecho, una exportación (si bien diferida) de una fracción importante de la renta insular, particularidad que los naturales no dejaron inmediatamente de percibir, como se revelaba en el pacto de Lérida de 1379 que hemos resumido.

Los extranjeros (y en mayor parte los catalanes) son los mayores demandantes de este tipo de pasivo, por aquello de que siempre pueden, caso de impago de las pensiones, resarcirse sobre bienes secuestrados a naves o a mercaderes mallorquines, como pasó de hecho en mayo de $1268^{79}$, y por ello a menudo disfrutaban de un trato de favor y de prelación en las "reducciones" de la deuda o pagos de pensiones retrasadas, como había pasado ya en el acuerdo de 1330 entre los acreedores de la "taula" o banca de los jurados y los reformadores remitidos por el infante Felip ${ }^{80}$.

De hecho, aun considerando los incentivos marginales de cierto grado de especulación, como es la posibilidad de adquirir títulos por precio inferior al nominal -dado el riesgo de suspensión o de largas demoras en los pagos por parte de la universidad-, o de pagar deudas contraídas -incluso con la misma universidad- en títulos devaluados, a lo largo de la segunda mitad del siglo cuándo la comunidad insular ya se debatía en la bancarrota "de facto" y los recursos de la isla eran insuficientes para cubrir la acumulación de imposiciones- no parece que las emisiones de censos y violarios fueran suscritas con excesivo entusiasmo por los insulares. Por eso en 1374 el Consejo tuvo que acordar que se "obligara" a adquirir censales a todos aquellos que habían acostumbrado a hacerlo en el pasado y el 3 de marzo de 1377 el rey encargó al gobernador que forzara a los particulares que él estimara oportuno a efectuar préstamos a la universidad bajo la forma de títulos, como tendría que practicarse de nuevo dieciseis años más tarde ${ }^{81}$.

\footnotetext{
${ }^{79}$ ARM Pergaminos de Jaime I no . 13. Vid. Historia económiça de Europa de la Universidad de Cambridge, ed. Revista Española de Derecho Privado, Madrid, 1967, Vol. III p. 673.

${ }^{80}$ ARM AH 436 f. 78 v a 79 v.

${ }^{81}$ ARM Colecc. E. Pascual papel, 104. También el 1393 el rey autorizó a los jurados y al Consell general de Mallorca para que obligara a determinadas personas a adquirir censales "morts". Vid. CATEURA, Sociedad y sistema fiscal. op. cit. p. 173.
} 


\subsection{Remisiones de "censales"}

El recurso de emitir nuevos censales para redimir los anteriores podía tener viabilidad caso de que hubiera desaparecido alguna carga o necesidad y que se diera, por lo tanto, la posibilidad de eliminar algunas pensiones y de aligerar la carga impositiva, si la nueva emisión iba a un tipo menor de "for" (precio o interés); o también podía suponer un cierto beneficio el hecho de redimir títulos viejos y devaluados por un capital menor del que se obtendría en conjunto de la nueva emisión, mientras el volumen de las pensiones se mantenía estable. Pero el descenso acelerado de los recursos de la isla en el último tercio del siglo, que fue paralelo al incremento de las obligaciones y del volumen de la deuda exterior, y quizás el desvío de capitales, restaron posibilidades de éxito a cualquiera de aquellos planes, lo mismo que pasó con los que se arbitraron para reducir las pensiones o para convertir los censales vitalicios ("violarios", que pagaban mayor pensión) en "morts" (sin plazo de amortización y, por lo tanto, a menor pensión)

Tampoco los jurados dejarían de aprovechar los momentos psicológicos de peligro para el reino en provecho propio ya que, por ejemplo, y entre otras muchas ocasiones, ya en el año de la primera emisión de censales que conocemos (1366), el 15 de septiembre, los privilegiados alegaban irregularidades de los jurados ante el emisario real Pauquet de Bellcastell, diciendo que aquellos habían desviado fondos destinados a los donativos comprometidos al monarca, para aplicarlos a sus necesidades.

Imposibilitados de reducir o de redimir la deuda, la única opción para hacerle frente era incrementar la recaudación de recursos.

\section{PLANES DE REFORMA, REESTRUCTURACIÓN Y SANEAMIENTO}

El método último y extremo para conseguir poner orden en la gestión de los jurados, o bien orientarla en el sentido deseado por la corona, son los planes de reforma y saneamiento que a veces parecen impuestos unilateralmente por el monarca, pero que frecuentemente responen a la presión o sugestión de diversos bandos dentro del mismo Consell General de la isla y que siempre están sometidos a la discusión y muchas de las veces enfrentados a la oposición del Consejo.

Conocemos diversos de estos planes, o los más destacados, que veremos brevemente acto seguido:

\section{9}

A mediados de siglo XIV, las cargas impuestas con la limitación de un número determinado de años no habían llegado a desvanecer la deuda que seguía creciendo o, al menos, manteniéndose. Eso podría implicar dos tipos de causas:

a) atribuibles a la recaudación:

-un error de cálculo en la estimación del volumen a recaudar; 
-el desvío o la malversación de parte de los fondos extraídos de los impuestos y que habrían sido hurtados a su destino, e incluso la imposibilidad de evitar el fraude y la evasión, lo que desequilibraría las previsiones de recaudación.

b) atribuibles a las necesidades:

-o bien por un incremento inesperado de las necesidades de la universidad;

-0 , su complementario, por un descenso grave de la capacidad productiva y contributiva de la isla, que hiciera imposible la previsión de llegar a un equilibrio en un tiempo corto o medio.

Fuera la situación, pues, la de un crecimiento sin cesar de la deuda o la de una reducción demasiado acelerada de los recursos productivos sobre los que gravaban los impuestos que tenían que aplicarse a enjugarla, la realidad parece ser que, ante la imposibilidad de alguna momentánea reducción de los gastos o del fraude que permitiera reducir (luir) parte de los censales, es decir, devolver de una vez el capital comprometido, y dado el carácter perpetuo o vitalicio de las pensiones que aquelos habían generado, éstas quedaban eternizadas y a cada nueva contingencia se iban añadiendo las nuevas emisiones a las pensiones de todas las anteriores, en un crecimiento imposible de detener, con el único consuelo de la esperanza en el aforismo "dia que pasa, año que corre" (dia que passa, any que empeny)

Esta situación obligó a un plan presentado por el Gobernador de la isla Gilabert de Centelles y aprobado por el monarca el 25 de noviembre de 1359, de que hemos dado antes breve noticia, que empezaba, significativamente, con las siguientes disposiciones relativas a las sospechosas finanzas de los jurados $^{82}$, en un intento de implantar un mayor control en la administración de los caudales públicos:

I.a) En lo sucesivo, todas las monedas que se tuvieran que ingresar en la casa de la Juraría de Mallorca serían depositadas en una "taula asegurada" bajo la garantía de los jurados, sin que ninguno de ellos pudiera disponer de cantidades, que se destinarían sólo a pagos a terceros que se tendrían que hacer exclusivamente "a taula", es decir, a través de la banca;

I.b) Para los gastos propios de la Casa de la Juraría inferiores a una libra, es decir, para disponibilidades de caja pendientes de justificar, los Jurados sólo podrían retirar hasta un máximo de 25 libras cada vez y sólo mediante albarán firmado por todos ellos o por la mayoría.

II. Los Jurados no podrían, en el futuro, acordar concesión de ninguna cantidad sin el consenso de todos los Consejeros de la ciudad y de la parte

\footnotetext{
${ }^{82}$ P. Cateura, Política, op. cit. cap. 4 p. 150 y doc. 71 . El plan contemplaba, además, disposiciones sobre nombramientos, misiones remitidas al monarca; salarios, dietas, provisión y renovación de cargos; aspectos judiciales; datación, registro, tramitación, tasas y extensión de los documentos públicos; normas sobre procedimientos notariales y pleitos; la obligación de redactar en "pla" (en la lengua vulgar) las recetas médicas; reglas para los exámenes de abogados y médicos desplazados desde otras localidades para ejercer en la isla su profesión; garantías de seguridad en la posesión inmobiliaria, mediante la prescripción a los 30 años de cualquier pretensión de dominio, y la no-exigencia de haber de aportar documentalmente testimonios de la posesión anterior a aquel plazo.
} 
foránea, o de la mayoría de ellos, y solo por un máximo de 5 libras cada vez y con un total de 50 libras al año, que podrían ser también libradas en una sola vez; todo ello con excepción de dones al monarca, a la reina y a su primogénito.

III. Tampoco podrían conceder adelantos o créditos a ningún comprador de ayudas, de imposiciones o de otros derechos de la universidad, sino por consenso de todos los consejeros de la ciudad y de las villas, o de la mayoría de ellos.

\section{3}

En 1373 la isla asistió a otro intento (inmediatamente frustrado) de un nuevo plan presentado en el que se contemplaba ${ }^{83}$ la reducción de las

\footnotetext{
${ }^{83}$ Vid. mi trabajo Comunidad y corona op. cit., cap. VI de la II ${ }^{\mathrm{a}}$ parte; ARM AH 1924 f. 29 y AH Libro de reforma del Consejo General, passim y especialmente f. 18 y 19, publicado por Antoni PONS en Constituciones y ordenaciones, op. cit.; ARM CEP papel no 103; P. CATEURA, doc. n 186; José QUADRADO, Islas Baleares, Palma de Mallorca, 1888, reedición de Lluís Ripoll, Palma de Mallorca, 1969, p. 100. El resumen de las disposiciones económicas de los reformadores es el que sigue:

1) Las "ordenaciones" empiezan con la declaración de que los ingresos de la universidad por diversos conceptos (imposiciones del reino, derecho del "agua del martes" y otros) subían cada año cerca de 45.000 libras de Mallorca; aún así los cobros no solían pasar de cerca de 33.000 libras, dado el caso de que "roman cascun any en poder dels compradors de les imposicions, per favor o per amor o per negligencia dels jurats o clavaris, o aquelles persones que han carrec", más de 12.000 libras. Este margen de fraude, malversación o tolerancia culpable tenía que cubrirlo la Universidad mediante el crédito, lo que suponía recargar el descubierto con intereses y cargas que, en razón, tendría que ir a cargo de los recaudadores retrasados. El documento de reforma dictaba instrucciones para detener este grado de fraude y añadía que, si se lograba, se podrían ingresar las 45.000 libras íntegras, y de ellas todavía sobraría cada año alguna cantidad para poder redimir los censales que tenia cargada la Universidad y los que a la fuerza tendría que poner en circulación para poder alcanzar el cumplimiento de algunas disposiciones de esta misma ordenanza que se verían más abajo.
}

2) Disponían la reducción de gastos, mediante la eliminación de algunos cargos y sueldos, y una reestructuración de los departamentos y servicios administrativos.

3). Dado el caso de que la mayor carga que tenía la Universidad eras los "violarios" y las pensiones de aquéllos, que subían cada año 20.815,5 libras, disponían que todos los "violarios" fueran reducidos y convertidos en "censales muertos", mediante el artificio siguiente:

-los violarios y los censales muertos que habían vendido a 10.000 sueldos por millar (es decir a un interés del $10 \%$ ), o a un tipo aún mayor, los rescatarían a razón de un 7,14\%, un 7,69 o, en caso extremo, a un 8,22\% (es decir, devolverían el capital con el premio indicado, con lo que rescataban la carga de las pensiones anuales); para alcanzar los caudales para llevar a cabo esta remisión, les autorizaban a poner en venta una nueva emisión de censales muertos;

-si no alcanzaban a encontrar compradores para la nueva emisión, los poseedores de censales violarios (vitalicios, al 10\% de pensión o más), verían sus pensiones reducirse a las que solían corresponder a los muertos (perpetuos, y por lo tanto a un "precio" o interés menor), que estaban alrededor del $8 \%$;

-en el futuro no podrían hacer más emisiones de censales ni de violarios, puesto que todos se habrían convertido en muertos, es decir, en deuda consolidada y los excedentes de la Universidad irían absorbiendo gradualmente sus pensiones;

4). La universidad pagaba cada año, además, las pensiones que correspondían a censales recibidos en grano (2.096 cuarteras, a 8 libras $=16.768$ libras de deuda), por las que pagaba de 18 a 20 sueldos por cuartera cada año (entre un 11,25 y un $12,5 \%$, con un total de $1886^{\circ} 4$ hasta 2.095 librạs por año) Los reformadores disponían la reducción de las pensiones hasta una equivalencia del $8 \%$.

5) Además, la Universidad tenía deudas, sobre la garantía de sus bienes propios, por un total de 2.941,44 libras, por las que abonaba pensiones equivalentes a un interés del $10 \%$ anuales. Disponían también reducirlo a un $8 \%$, exceptuando las 200 libras que pagaban bajo este concepto al hospital de Sant Andreu.

6) La universidad pagaba también cada año, por intereses de una parte de las sumas recibidas en préstamo aún pendientes de amortización, las cantidades siguientes:

I- por las 1.589,46 libras de las que, desde hacía 18 años, seguían abonando de renta un interés del $10 \%$, como resto pendiente de amortizar del don de 83.000 libras concedidas al rey Pere en 1354 ; 
pensiones anuales del 10 al $8 \%$, el rescate (mediante una nueva emisión de censales) de títulos al $10 \%$ capitalizados en una banda que oscilaría entre el 7'14 y el 8 '33\% (lo que indica su descendente apreciación en el mercado) y la suspensión del pago de intereses de algunos créditos, por espacio de diez años.

El plan lo presentaron el día 3 de enero de 1373, junto con el gobernador de la isla Olfo de Próxida, Berenguer de Abella, vice-gobernador general de Cataluña, y Pere Sacalm, auditor de la curia real, que habían sido designados por carta del monarca dada en Barcelona el 20 de diciembre, y estaba contenido en un extenso documento de reforma de las finanzas de la isla elaborado con bastante esfuerzo por la cancillería real "hauda clamor de la mala administracio e regiment d.aquest regne" y previa la advertencia de que, fueran o no del gusto de los jurados y consejeros, las "ordenanzas" no constituían materia negociable puesto que, como lo manifestaba el mismo reformador Abella: "en aquelles en res per nos no si pot tochar ni mudar" 84 .

II- por 3.117 libras que debían a diversas poblaciones de la isla por lo que restaba devolver de los excedentes que les habían llegado en préstamo para el don de 25.000 libras hecho al rey en 1355 para la guerra de Cerdeña, que estaban pagando un interés del $15 \%$ desde hacía 17 años; III- por 560 libras que debían al hospital creado por Salelles, que habían pagado intereses del $10 \%$ anual por espacio de 16 años:

IV- por 233,5 libras que debían a diversos compradores de unos cautivos moros que, por orden del rey, habían tenido que ser restituidos al rey Bonian, por las que habían pagado un $10 \%$ anual por espacio de 10 años;

$V$ - por 11.804'85 libras que debían al mercader Arnau de Termens y sus socios por las mercancías que habían perdido en el "leño" de Berenguer Gassó, que fue capturado por dos galeras armadas del rey Boannen en represalia por las pérdidas de mercancías que le habían causado dos galeras armadas de la Universidad misma, por las que pagaban interés de $10 \%$ desde hacía 14 años;

VI- por 5.814,5875 libras que habían recibido en préstamo hacía 4 años, de las que una parte capitalizaba a un $10 \%$, una parte a un $12,5 \%$ y una parte a un $20 \%$.

Todos estos conceptos (y otros que los reformadores no describen) subían a un principal de $32.980,95$ libras, que disponían que se amortizaran dentro de los próximos siete años, a razón de 4.711 ' 55 libras por año.

7) Además, la Universidad había pagado intereses sobre cantidades que habían recibido en préstamo, de manera "voluntaria". A los reformadores no les parecía bien que la universidad actuara "voluntariamente" sin que los respectivos acreedores se lo hubiera requerido:

I- 2.348 libras de sobrante de lo que le habían dejạdo en préstamo en 1349 en razón del desembarco en la isla de Jaume III, en que perdió la vida

II- 5.240 libras de sobrante de las 10.000 que le habían dejado en 1354 por el donativo hecho al ry cuando estaba en Cerdeña

III- el resto del préstamo que recibió para armar las galeras y las naves que en 1359 se habían armado en Mallorca a causa de la invasión de Ibiza por el rey de Castilla.

Los reformadores disponía.n que se suspendieran los pagos de estas cantidades por espacio de los próximos 10 años y que a solo se reprendieran si la disponibilidad lo permitiera.

${ }^{84}$ ARM AH 1924 F. 29 y AH 5326 Libro de reforma del consejo general, op. cit. en la nota anterior. La reforma no tuvo casi viabilidad. Por ejemplo, el $18 \mathrm{de}$ diciembre del mismo año 1373 , a pesar de la prohibición expresa hecha en las "ordenaciones" de que la Parte Foránea de la isla pudiera imponer tallas por su cuenta en las respectivas villas para sus necesidadẹs, el rey dictaminaba que, por mucho que la licencia del gobernador seguiría siendo preceptiva en la imposición de tallas comunes (pọ toda la isla), se poḍía prescindir cuando se trạtara de recaudacionẹs para obras necesarias dentro de un municipiọ (reparación de puentes, iglesias, calles y caminos, cursos de agua, etc...) La crisis de las subsistencias, por aquel mismo tiempo, es la mayor preocupación de los prohombres y del gobernador. El mes de junio dictaban disposiciones, hacían propuestas y adoptaban provisiones para acaudalar trigo: se creó una "taula asegurada" para recoger préstamos a un año hasta un total de 30 o 40 mil reales de oro a un 8 o un $10 \%$, y obtuvieron licencia para emitir una nueva serie de "censales muertos" hasta las 3.000 o 4.000 libras necesarias para hacer frente a sus intereses, que se pondrían a la venta en la isla o en Barcelona y al mismo tiempo se les concedían moratorias en el pago de las deudas y una prórroga de cinco años en el plazo que les habían fijado para empezar a redimir (reembre) los censales, medidas que malbarataban, antes de que se hubieran empezado a aplicar, los extremos 
El reino había declarado la suspensión de pagos, lo que provocó la suspensión también de las facultades impositivas del Consell General relativa a las "tallas" -que pasaría a manos del gobernador-, y de hacer nuevas emisiones de deuda, el reconocimiento oficial del Sindicato foráneo a finales del año y una aluvión de acreedores que pronto remitirían sus requisitorias y delegados a la isla, a cargo de la parte deudora.

El momento era inoportuno: la isla se encontraba a las puertas de la mayor crisis agrícola del siglo y en el descalabro que originó la reforma, el monarca todavía ejercía fuertes presiones para obtener que se recaudase de antemano un "monedatge" cinco años antes de lo que correspondía (que era cada siete años) para la defensa de Molina, amenazada por Enric de Trastámara, además de un subsidio que estimaba en 60.000 florines, a tenor de aquello que había obtenido de Cataluña, aunque se conformaría de momento con las 10.000 que le ofrecían como adelanto.

No parece que el plan fuera aplicado con entusiasmo, ni siquiera que fuera totalmente aplicado puesto que, al cabo de poco tiempo, y ante el alud de reclamaciones de los recaudadores y de los particulares afectados por confiscaciones y liquidaciones de deudas antiguas a la universidad y por la reducción de las pensiones, la situación catastrófica de la isla ante las peores añadas del siglo entre 1373 y 1375 y las necesidades del mismo monarca, en agosto de 1374, ante los catastróficos momentos que estaba viviendo la isla, el rey tuvo que promulgar toda una serie de disposiciones que revocaban en parte las de Abella, entre ellas las que exigían de los foráneos que habían pasado a vivir en la ciudad que siguieran tributando en el lugar de donde provenían y otras disposiciones proteccionistas, como eran las moratorias de deudas y censales ${ }^{85}$ y que todavía se deberían en 1405 cuando se firmó el "contrato santo". En octubre de 1374, y en un documento dado en Barcelona el día 6 de aquel mes, dentro del proceso a Bartomeu Ses Eres contra la Universidad que aparece en el mismo registro, aparece, según el prof. Cateura, la primera moratroria por deudas (por 3 años) concedida por el rey a la Universidad de Mallorca.

fundamentales que eran el cimiento de la reforma gestionada por Abella. El año de 1375 transcurre dentro en el seno de la crisis económica y agraria y de las contenciones, pánicos recursos, ruegos, exigencias y, expedientes originados por el proyecto de reforma de Abella. El saneamiento de las finanzas públicas imponía un alud de embargos en ejecución de deudas que se tenían con la Universidad, agravado por los perjuicios que se había causado a las inversiones privadas con la arbitraria reducción de las pensiones de los censales garantizaḍos por la Universidad. La ocultación de bienes y la fuga de capitales habían acompanado los intentos de los reformadores; la moratoria de las deudas dictada por el rey no era respetada por los oficial públicos, que veían la ocasión de ejercer sus funciones con toda inclemencia y de beneficiarse de los posibles porcentajes, corretajes y -por qué no- sobornos. La moratoria tuvo que ser confirmada por el rey el 2 de marzo; el 8 de agosto ordenó la anulación de los procesos o ejecuciones sobre los bienes de los deudores de censales en especie; el día 31 tuvo que regular el máximo que se podía recibir por cada "cuartera" de trigo censal y en septiembre tiene que amenazar con pena de decapitación al alcalde de la ciudad, si no suspende las ejecuciones forzosas a foráneos que eran deudores de censales, insistiendo en lo que había dispuesto el 8 de agosto. La escasez de grano había impulsado al monarca a ordenar el 26 de junio anterior que la Universidad enviara armadas para capturar cualquier nave cargada de grano que se pusiera al alcance, mientras los precios, según todos los testigos, se habían disparado a niveles astronómicos. Vid también CATEURA, Pau Sociedad y sistema, op. cit. pp. 183-183.

${ }^{85}$ ARM LR 29 f. 219. 
La última estocada a la reforma de Abella se la proporcionó el donativo obtenido por el monarca en Monzón en 1376, que no dejó de llevar las habituales contrapartidas: a la vez que el rey ponía como condición que las lanas que no fueran de la tierra -y especialmente las de Venecia y Pisaestuvieran exentas de derechos ${ }^{86}$, revocaba gran parte de lo que todavía subsistía de la pragmática dictada por Abella y el gobernador Olfo y concedía de nuevo al Consejo y a la universidad la facultad para poder obtener "a su arbitrio" cualquier cantidad para sus necesidades, y para hacer omisión de todo lo que contenían las ordenanzas de los reformadores en contrario ${ }^{87}$; tan sólo un dia después (el 31 de mayo) el monarca dió su autorització a los Jurados y los Síndicos, tanto de la ciudad como de las villas, para vender censales muertos y violarios, es decir, para incrementar la deuda, "no obstant qualsevol prohibició anterior" 88 y autorizó también a los jurados de la isla a imponer" nuevamente" y por el tiempo necesario ayudas, imposiciones y generalidades sobre pan, vino, mercancías, carne y otros artículos cualesquiera y también a incrementar, si lo estimaban oportuno, las que pudieran ya existir, tanto para cubrir el ofrecimiento que le habían hecho las Cortes de Monzón como para responder de las pensiones de los censales muertos y violarios que para hacerla efectiva tendrían que emitir de nuevo, al mismo tiempo que les concedía una prórroga de dos años para pagar todas sus deudas ${ }^{89}$. Todo ello suponía una recarga grave sobre las finanzas de la isla y la total imposibilidad de saneamiento de las cuentas públicas.

Como último y extremo recurso, en 1377 se vio por fin la universidad obligada a "consignar" (es decir, inmovilizar) en caja aparte -como un antecedente del "contrato Santo" de 1405 que hemos visto- ocho impuestos por un importe global de 25.000 libras el año, con el fin de respaldar una nueva emisión de censos y violarios, lo que indica que el grado de confianza de los eventuales compradores era muy próximo a cero o que las cuentas del común habían llegado definitivamente al estado de absoluto marasmo.

\section{8}

En las postrimerías del siglo la conclusión del nuevo monarca de la Corona de Aragón, Martí, era que "lo comu e universal regiment e Consell freturava de reformatio e reparatió e al present esser, per ambiciositat de regir e hauer a sa ma lo dit regiment e consell, e en altre manera, en gran diuisio".

Era cierto: en el seno del Consejo se vivía un estado permanente de lucha por el control del poder; por el favor del Lugarteniente, que intervenía descaradamente en sus decisiones; para ganarse los foráneos o su voto, aun aprovechando la continúa situación de agravio de aquellos por parte de la ciudad; por el control de las elecciones, que había inspirado numerosas

\footnotetext{
${ }^{86}$ ARM CEP papel 120, dado en Monzón el 21 de mayo de 1376.

${ }^{87}$ Dado en Monzón el 26 de mayo. Vid. CATEURA, doc. 223 y ARM Códice Sant Pere f. 183 v (fechado en el mes de marzo).

${ }^{88}$ ARM CEP papel 172 .

${ }^{89}$ ARM CEP papel 204.
} 
reformas ${ }^{90}$ y verdaderos enfrentamientos; por la mediación e influencia en los asuntos económicos y para alcanzar la participación en las comisiones que tenían que evaluar la cantidad y el precio por el que podrían ser exportados algunos excedentes y también las primas a ofrecer por las importaciones de grano en los momentos de carestía, que a menudo iban a parar a amigos de los consejeros o a sociedades en las que alguno de ellos participaba.

Pedro IV ya había tenido que prohibir de nuevo a los clavarios de la universidad el comprar por ellos mismos o mediante personas interpuestas o testaferros la recaudación de los impuestos ${ }^{91}$, una práctica, por lo que se ve, frecuente en la corrupta administración mallorquina si consideramos que el 29 de enero de 1372 una disposición del mismo monarca nos informaba que el total de lo acumulado por diversos deudores a la universidad, a causa del favoritismo a favor de socios, parientes, deudores o amigos, era de 25.000 libras, un tema al que ya había hecho referencia cincuenta y tres años antes la sentencia del rey Sanxo de 1315. Al año siguiente, según las manifestaciones del reformador Abella, el nivel de fraude y de lo que restaba impagado a las arcas comunales era de 12.000 sobre 45.000 libras anuales: un $27 \%$ de la recaudación.

La reforma de 1398, aplicada por Huc de Anglesola, que había sido nombrado virrey de la isla -la primera vez que aparece el título-, y que moriría dos meses después, en agosto del mismo año, en una desafortunada y caballeresca incursión marítima en el norte de África, consiste en una Pragmática $^{92}$ que disponía un nuevo y riguroso sistema de elección y de

\footnotetext{
${ }^{90}$ Barcelona 25 de diciembre de 1373 , Tortosa 29 de noviembre de 1382 -pragmática "de vida"-, Barcelona septiembre de 1387, Villafranca del Penedès 13 de diciembre de 1387, Barcelona 1390 y Pedralbes 24 de julio de 1392.

${ }^{91}$ ARM CEP papel doc. 149 dado en Zaragoza el 15-6-1366.

${ }^{92}$ ARM Códice de Cortes Generales. Afectaba a los oficios de alcalde, veguer de la ciudad, veguer de fuera y sus asesores; notarios, escribanos, clavario y oidor de cuentas; abogado o asesor del notario del Consejo, el clavario, del "tauler" u oficial de la taula de cambi y del síndico. El contenido de la Pragmática es, en síntesis:

a) Miembros del Consejo General:

-que pudieran acceder a los oficios de la Universidad personas de cualquiera de los estamentos que formaban el Consejo General, siempre que la elección lo impusiera así, excepto el mostaçaff (ạlmotacén, que sólo lo podían ser militares y ciudadanos) y el ejecutor (sólo militares, ciudadanos o mercaderes);

-edad mínima de 20 años para ser consejero o para desempeñar cualquier oficio de la Universidad y la obligación de ejercer los cargos para los que los hubieran elegido, con la prohibición de ejercer dos a la vez, excepto los consejeros, que podían ejercer otro oficio de la misma Universidad, o el jurado u otro oficial que fuera jurista y fuera elegido como abogado o asesor, -la privación del oficio a aquellos que hubieran cometido fraude o engaño en algún oficio o administración de bienes de la Universidad, pọr mucho que hubieran llegado a composición (hubieran indemnizado a la Unniversidad o al perjudicado) una vez que hubieran sido condenados civilmente o por la jurisdicción criminal.

b) Oficiales públicos:

-funciones y salarios del abogado, notario, escribano y clavario, exactores y síndicos;

-oidores de cuentas, cónsules del mar y veguers de la gobernación;

criados, mensajeros y los dos veedores (inspectores de obras) de los mostaçaf, acequiero mayor y sus criados, y los emolumentos correspondientes;

-pendones y penoneros y gastos para las fiestas;

-talayes (vigilantes permanentes en las torres costeras) y scoltes (vigilantes ocasionales).

c) Salarios de oficiales a cargo de la Universidad y rẹgulación de las plazas:

-salario del relojero -que tendria que ser elegido por los jurados-, de los guardianes del mar y del puerto, para la guarda del faro y el muelle de Porto Pi (que se limitaria a 4 agentes) y de los corredores de las ventas de derechos y del victigal, uno de los cuales haría de trompeta o
} 
provisión de cargos y una nueva estructura del Consejo; regulaba los diversos oficios; la tributación de los monederos, que no tenían derecho a cargo público si se consideraban exentos de contribuciones; la representación foránea y la composición de las embajadas que las diversas facciones que buscaban el control del Consejo a menudo enviaban al monarca.

A la pragmática acompañaron dos más: la primera de ellas ${ }^{93}$ trataba de la abreviación de los pleitos y de la administración de justicia; la segunda regulaba algunos aspectos económicos, junto con otras disposiciones para reducir los gastos:

-control de la gestión económica de las "ayudas" impuestas para la adquisición de trigo en los casos urgentes;

-la obligación de realizar un inventario de bienes, de deudores y de acreedores y de fijar las garantías que tenían que depositar los compradores de derechos;

-el control y la revisión semanal de cuentas entre el "clauari" (el tesorero) y el "tauler" (el cajero);

-la gestión de la "taula" y la administración de las cantidades que eran depositadas en ella;

-la prohibición de remuneraciones extraordinarias a los asalariados del Consejo General y la imposición de sanciones por la falta de asistencia a sus sesiones;

-la reducción de los honorarios de los representantes de la parte foránea y la supresión de los 100 reales de oro al año que recibían los síndicos de las villas y parroquias para gastos comunes de la parte foránea, y de los otros 150 que se abonaban a sus síndicos, que habían sido ya revocadas por el rey anteriormente;

\footnotetext{
"corredor de las cortes" en los llamamientos que ordenara hacer el Consejo;

-fijaban una pensión anual de 100 libras al médico (con la recomendación de que prescindieran del actual, Francesc de Totxo, si encontraban otro más adecuado);

-irían a cargo de los jurados el salario del maestre guayta (encargado de la vigilancia de los esclavos, cargo que Pere IV había revocado y después lo había restituido) y el salario y selección de 14 personas que harían las guardias de noche a sus órdenes;

-autorizaban a nombrar un escribano -caso que se votara la imposición de una talla- para llevar todo el papeleo correspondiente;

d) Reducciones de salarios a oficiales y cargos de la Universidad:

-disponían que los jurados tendrían que elegir, a la vez que reducían los salarios correspondientes, los cargos de: guardas del alfóndec (alhóndiga), dos veguers de la sala (eliminaban las plazas de guarda y las de algunos criados), los que pesaban la paja y el carbón, el tesorero que té lo marc e la guarda de ta moneda, el aleyador (que hacía las aleaciones del metal para hacer las monedas), que era el otro guardián, y del pesador del mercado del hilo; de los reebedors del peso de la mercadería, que les quitaban el salario, que tendría que ir a cargo de los mercaderes propietarios de las ropas y mercancías que se pesaran.

e) Supresión de plazas y salarios:

-revocaban el oficio del capdegayta que tenía que requerir a los deudores en la Universidad por no ser oficio provechoso ni necesario;

-suprimian el estipendio de 12 libras al año a los dos trompetas y el salario a los dos ejecutores de la Universidad y al capitán de Alcudia (que se llevaba 100 libras cada año).

${ }^{93}$ La primera está en el Códice de Franquezas del ARM -pragmática de 31 de junio de 1398la segunda, que está en el Códice de Cortes Generales del mismo archivo, introducía instrucciones como que las deposiciones de testigos se escribieran "en pla" y no en latín, que los notarios y escribanos fecharan los documentos por días y meses y no por idus, nonas y kalendas, y la prohibición de que cualquier oficial real o de la Universidad pudiera asistir los días laborables a bodas o funerales, a no ser que fueran de algún pariente hasta el tercer grado o de prelados y otros oficiales.
} 
-por otro lado, fijaba el pago de 1000 libras anuales, a anticipar de los bienes de la universidad, a los síndicos de la universidad foránea, en pago de cuanto les debían aún de los préstamos que habían hecho a los jurados para las guerras de Castilla y de Cerdeña ${ }^{94}$ y que todavía se lo deberían en 1405 cuando se firmó el "contrato santo".

Los contenidos de la reforma son los que hemos visto todo el tiempo y a lo largo de todo el siglo y que ofrecemos a modo de conclusión:

-escaso, fraudulento o imposible control de los caudales públicos;

-inflación de cargos, gratificaciones y salarios a favor de los integrantes del Consejo General y de sus afines, con carices de nepotismo, de favoritismo y de corrupción;

-una deuda importante por parte de los "compradores" (recaudadores) de las imposiciones y ayudas, con indicios muy fundamentados de complicidad o confabulación con alguno de los mismos jurados;

-continuados agravios y expolios y la hostilidad y el trato diferencial gravoso dado a los foráneos, con carácter a veces de "castigo", del que no eran ajenos los mismos reformadores, que les regateaban salarios, dietas y gramallas ("com... no sien homes de tan gran estament que degen haver tan gran salari”, afirmaba el reformador Abella, cuando les redujo a 1/3 la dieta de 6 sueldos / día que recibían para asistir al Consejo).

\section{LA UNIVERSAL CONSIGNACIÓN}

Todo eso llevó hasta la Consignación de 1405 que consistió en la renuncia por parte de la universidad a la recaudación de los impuestos existentes, que fue transferida a los mismos acreedores a fin de que de su volumen se pudieran resarcir a partes proporcionales de las pensiones de su deuda, documentada a través de los "censales" o títulos de deuda emitidos por la administración de la isla.

El tema ${ }^{95}$ ha atraído la atención de los historiadores, puesto que supuso la total hipoteca de las finanzas públicas mallorquinas en manos de los

\footnotetext{
${ }^{94}$ En los momentos de la reforma de Abella y de la gran crisis agrícola de 1373/75 los foráneos, por su lado, no paran de acosar a la universidad con reclamaciones de intereses de las cantidades que las villas le habían adelantado en 1354, sin hacer caso de las ordenaciones de Abella. En agosto de 1374, ante los catastróficicos momentos que estaba viviendo la isla, el rey tuvo que promulgar toda una serie de disposiciones que revocaban en parte las de Abella, entre ellas las que exigían de los foráneos que habían pasado a vivir en la ciudad que siguieran tributando en el lugar de donde provenían y otras disposiciones proteccionistas, como eran las moratorias de deudas y censales.

${ }^{95}$ El tema ha sido muy trabajado, después de los estudios convertidos en casi clásicos de José JUAN VIDAL, La problemática de los censales: su incidencia en las germanías (1521-1523), "Mayurqa", 13 (1975); Lleonard MUNTANER I MARIANO, Dependencia económica y reproducción estructural del endeudamiento público en la isla de Mallorca, "Ier. Colloque du Centre Universitaire de la Romania, Bastia-Córcega, 1978", Barcelona, 1982; Álvaro SANTAMARÍA, Sobre el antisemitismo, op . cit.; ID., Sobre la gestión físcal y la coyuntura económica la Mallorca en torno al año 1510, "Mayurqa", 14 (1975); ID. La deuda pública en la parte foránea de Mallorca al finalizar el siglo XV, "ẢEM" 8 (Barcelona 1972-73). Del mismo autor, el capítulo 2 de Mallorca en el siglo XIV, en el tomo İII de Historia de Mallorca coordinada por J. Mascaró Pasarius, Palma de Mallorca, 1978.
} 
acreedores, mayoritariamente catalanes en principio (y concretamente barceloneses), por mucho que, según el profesor Santamaría ${ }^{96}$ pudiera tener algún mérito el hecho de que los esfuerzos de los jurados llegaran a convertir en interior la deuda exterior cuando, a mediados del siglo, alcanzaron a transferir la mayor parte de los censales a manos de mallorquines. En verdad, el único beneficio -aunque indudable- de esta transferencia fue el ahorro en gastos de pleitos y reclamaciones, que iban a cargo del deudor: en este caso la universidad de la isla.

El 17 de mayo de 1405 establecieron la concordia llamada "contrato santo" por el que la universidad y reino cedían y consignaban a los acreedores censalistas de Mallorca todas las imposiciones, gabeles, vectigals y derechos impuestos hasta el momento, a fin de que ellos mismos, o sus diputados, mediante un tesorero que tendrían que designar, cobraran todos sus réditos. El citado tesorero se obligaría a pagar las pensiones de sus censales a los acreedores de Barcelona, con el fin de excusar las costas de las ejecuciones; el excedente se distribuiría a partes proporcionales entre los acreedores de Mallorca, por un igual, con pacto de que, si no fuera suficiente para las pensiones de los mallorquines, la universidad de la isla debería suplirlo de otro dinero obtenido mediante una "talla" o derrama entre los pobladores, de la misma manera como en lo sucesivo tendrían que obtener los recursos para mantener los gastos propios de la misma universidad.

La misma Junta de la Consignación actuó como entidad de crédito y llegaría a hacer préstamos a la universidad de Mallorca al 8\%, mientras que antes no encontraba quien le quisiera dejar dinero ni siquiera al $10 \%$.

La cesión definitiva de la íntegra facultad impositiva llegaría el 28 de agosto de 1413 cuando viendo "la gran diformitat e desraglament en l'administracio de les monedas comunes de dit reyne" y siéndole preciso a la universidad satisfacer 30.000 libras en que se hallaba empeñada, tuvo que cargarse con nuevos censos y, por lo tanto, tuvo que introducir nuevos impuestos y gabelas para abonar las correspondientes pensiones. Por eso, puesto que la universidad no tenía ya crédito ni posibilidad de endeudarse, tuvo que encargar a los propios diputados de la Consignación de Mallorca que obtuvieran los caudales, emitieran los censos y recaudaran los impuestos, y tuvo que ceder a la Junta de la "Universal Consignación" todos sus derechos sobre el cobro de los impuestos, la emisión de censales y el pago de las pensiones, con idénticas facultades que las que tenía antes el reino, que ahora mantenía solo una teórica facultad normativa, sin capacidades ejecutivas.

La situación se pudo mantener hasta 1425 en que el estado de necesidad de la isla determinó que tuvieran que acordar dejar en suspenso los pagos a los acreedores de Cataluña (a los que les debían ya pensiones atrasadas), con el fin de utilizar el capital así retenido en enjugar las deudas de la universidad y redimir censos, acuerdo que provocó un alud de procesos

\footnotetext{
${ }^{96}$ Álvaro SANTAMARÍA, Sobre la gestión op. cit. Id. Mallorca en la primera mitad del siglo XV, "IV CHCA", Palma de Mallorca, 1955.
} 
y de recursos por parte de los catalanes que, siendo los costes a cargo del deudor -la universidad de la isla- resultó todavía más gravoso.

$\mathrm{Si}$ algo le restaba a la universidad de la isla no podía permanecer en sus manos por mucho tiempo, mientras se fuera incrementando el endeudamiento público. En esta situación los mallorquines solicitaron la ayuda real y la reina María resolvió el 5 de julio de 1431 que los censos de los catalanes se redujeran a razón de 24 por 1 (al 4 ' $155 \%$ ) y los de los mallorquines a razón de 30 por 1 (al 3,333\%); la reina dictó una emisión de censales a este tipo para satisfacer las pensiones atrasadas y transfirió a los acreedores de Cataluña la consignación de todos los impuestos, derechos y bienes de la universidad y reino, aunque serían recaudados por los jurados -con la intervención de dos "clavaris bolsers", uno de ellos nombrado por los acreedores y el otro por la universidad- que tendría que dar cuenta cada año a la junta de acreedores catalanes.

Esta situación desigual desagradaría también a los mallorquines, que obtuvieron una nueva sentencia del rey Alfons el 5 de junio de 1432 por la que los censos de los acreedores mallorquines se tendrían que abonar a razón de 17 por 1 (es decir, al 5 '88\%), y tendrían que hacer emisión de una nueva serie de censales o referiments para recaudar el capital preciso por tal abonar las diferencias que debían a estos acreedores. No tiene nada de extraño que, dado el mayor tipo aplicado a los acreedores de Mallorca, a partir de aquel momento, y en pocas décadas, se produjera la transferencia de títulos a manos mallorquinas, donde eran más retribuidos.

\section{EL PESO IMPOSITIVO}

Es imposible cuantificar de cualquier manera la carga que suponía sobre el comercio y el consumidor la aplicación y la acumulación de los diversos impuestos, sobre todo si no tenemos índices seguros del nivel de consumo y de auto-consumo, ni posibilidades de calcular salarios o entradas medias, ni el peso de la circulación monetaria, que es muy diverso (de poco a nada) en los diversos lugares e instantes.

Solo algunos acontecimientos políticos, como la revuelta armada de 1391 -a que tendremos que referirnos más tarde- y otras poco conocidas, nos podrán dar, cuándo sean debidamente estudiadas, una idea próxima de hasta qué punto podía haber llegado a ser posible, en las postrimerías del siglo XIV, la expoliación del productor, la presión contributiva y el odio hacia los exentos, aquellos precisamente que se apropiaban de los excedentes de la comunidad productiva mediante la posesión gratuita de bienes raíces, tascas y diezmos sobre la producción agraria y que ejercían privilegios que los eximían de las tallas y de las colectas que la universidad de la isla imponía para las necesidades ordinarias de la comunidad.

Veamos ahora con más detalle el primer aspecto, pues ya hemos visto en el primer capítulo lo esencial de la problemática de los exentos. 
Los recargos más importantes, de los que podemos cuantificar en porcentajes, son los que gravan el consumo de los tres productos de primera necesidad -pan, carne y vino- que aparecen desde 1309, y a ellos se añadirá el impuesto sobre los textiles, que se cargarán desde 1328.

A mediados del siglo, las tasas más frecuentes sobre estos productos eran:

-en la "móliga", venta y fabricación de pan y de harina se cargaban de 12 a 16 dineros por libra ( 5 a 6,25\%) aunque en algunos momentos fue más elevado: en 1359, que lo duplicaron de manera transitoria -junto con los otros impuestos- a consecuencia del asedio de Ibiza por las naves castellanas; en 1361, que lo recargaron con 4 dineros más, y en 1395, que llegó a 30 dineros (12 '5\%) que en 1418 llegarían a incrementar en un 10\%, lo que promovió unánimes protestas de las villas y el estado de desobediencia civil, incluso de los mismos alcaldes y oficial públicos;

$-1 / 5$ a $1 / 6$ (16 a $20 \%$ ) sobre el consumo de vino al por menor;

-12 a 15 dineros por libra ( 5 a $6,25 \%$ ) en el corte y venta de tejidos

-la sisa de las carnes era variable según el tipo, y a principios del siglo oscilaba entre un $9 \%$ y un $14 \%$, tasas que continuamente eran incrementadas hasta que llegaron a ser entre un $27 \%$ y casi un $43 \%$, como veremos.

En 1321 impusieron cargas también sobre los mercaderes y sobre la percepción de censos y de otros agrers y en 1331 gravarán también las ventas de ganado, las recolecciones y cosechas, la importación de cautivos, las ventas de pescado fresco y salado, los contratos agrarios, la compra y la importación de variadas mercancías y las manufacturas en la parte foránea.

En 1359 las carnes, los granos panificables y los tejidos, según los jurados, serian los únicos productos que podrían soportar aún un aumento del recargo tributario, con la finalidad de poder construir y armar cuatro galeras que el monarca solicitaba, puesto que los demás caudales recaudados por otras "ayudas" ya estaban destinados a otros usos y resultaban, además, insuficientes.

Con el fin de poder calibrar la carga fiscal tendríamos que considerar, además, otras cargas como eran los derechos de "corretoria" y de mercado, los de "cuartera" y de almacén, de registro, de "taula", de puertas, peajes (el del vino aparece citado desde 1335) y de peso y medida (de que estaban exentos sólo los ciudadanos y, después de 1344, también los foráneos), a las que podríamos añadir también las distintas tallas y subsidios vecinales, el "morabatí" septenal y, en su caso, los derechos de importación, de exportación o de paso de mercancías (lleudes, impuestos sobre el cargamento de naves, derechos de puerto, entradas y salidas, de embarque, etc...).

En cuanto a la repercusión tributaria sobre el consumo último, deberiamos considerar todo ello superpuesto a cargas no contributivas como diezmos, tascas, censos, laudemios y otras obligaciones reales aplicadas en el origen y pudríamos también considerar añadidos a los recargos sobre las cosechas de grano las deducciones para las yeguas que debían trillar y el pago en especias a segadores que en algunas villas llegaban, conjuntamente, hasta el 7 '5\%; o podríamos intentar imaginar lo que le restaba al enfiteuta o el 
aparcero, una vez que había detraído la semilla para el año próximo, de una cosecha que tenía un rendimiento a menudo no superior a los 4 o 5 granos por uno, o podríamos intentar calibrar la muy pobre calidad de las viñas autóctonas, que hacía que quizás más de la mitad del vino se agriara en pocos meses, o la incidencia de las epidemias, sequías y hambres que a menudo disminuían el ganado.

Aun así, no nos es sencillo poder medir la carga final sobre el consumo, del que tampoco tenemos bastantes parámetros, pero intentaremos dar algunas indicaciones más detalladas de lo que podemos saber de los productos más corrientes y necesarios.

\subsection{Pan y harina}

En el caso del grano, por ejemplo, en las posesiones que no eran de la porción del rey, los productores abonaban al señor del dominio ${ }^{97}$, entre diezmos y tasca, un 17 ' $5 \%$ del total producido. A ello tenemos que añadir las cargas sobre la panificación:

A) En la ciudad, el impuesto de la "molige", en 1390, suponía que cada cuartera de grano o cada quintal de harina pagaba:

\begin{tabular}{|l|l|l|l|}
\hline & trigo & mescladizo y otros & cebada \\
\hline $\begin{array}{l}\text { Molienda o impor- } \\
\text { tador privado }\end{array}$ & 18 dineros & 13,5 dineros & 9,0 dineros \\
\hline Consumo privado & 9 dineros & 7,00 dineros & 4,5 dineros \\
\hline Total & 27 dineros & 20,5 dineros & 13,5 dineros \\
\hline
\end{tabular}

Además, la compra de harina al por mayor la cargaban en 3 dineros por libra ( 1 el vendedor y 2 el comprador, a menos que fuera para su consumo priopio o el de su familia) y en 4 en el caso de los que lo adquirieran para revender ( 2 el comprador y 2 el vendedor)

Conocemos ${ }^{98}$ tablas de algunos precios de distintos tipos de grano y de harina, lo que nos permitirá evaluar la incidencia que tenía el impuesto de la "molige" sobre el consumo de pan en las postrimerías del siglo:

[los precios van en dineros; el recargo de la "molige" o la tasa impositiva se calcula sobre la base de las cantidades anteriores y en dineros por "cuartera" (40,34 litros) en el caso del grano y en dineros por "quintal" (47,764 litros) en el caso de la harina de trigo]

\begin{tabular}{|l|l|l|l|l|l|l|}
\hline año & $\begin{array}{l}\text { precio } \\
\text { trigo }\end{array}$ & $\begin{array}{l}\text { tasa } \\
\text { "molige" }\end{array}$ & $\begin{array}{l}\text { precio } \\
\text { cebada }\end{array}$ & $\begin{array}{l}\text { tasa } \\
\text { "molige" }\end{array}$ & $\begin{array}{l}\text { precio } \\
\text { harina }\end{array}$ & $\begin{array}{l}\text { tasa } \\
\text { "molige" }\end{array}$ \\
\hline
\end{tabular}

\footnotetext{
${ }^{97}$ Josep Francesc LóPEZ Bonet, Un algoritme medieval, "Lluch", Mallorca, mayo de 1986.

${ }^{98}$ ID. La riqueza de Mallorca op. cit. apéndice III.
} 


\begin{tabular}{|l|l|l|l|l|l|l|}
\hline 1386 & 180 & $15,00 \%$ & 126 & $10,71 \%$ & 228 & $11,84 \%$ \\
\hline 1387 & 240 & 11,25 & 120 & 11,25 & 216 & 12,50 \\
\hline 1389 & 240 & 11,25 & 120 & 11,25 & 216 & 12,50 \\
\hline 1392 & 186 & 14,59 & 96 & 14,60 & 180 & 15,00 \\
\hline 1393 & 240 & 11,25 & 84 & 16,07 & & \\
\hline 1395 & 170 & 28,23 & & & & \\
\hline 1396 & 156 & 30,77 & & & & \\
\hline 1397 & 162 & 29,63 & & & & \\
\hline
\end{tabular}

En caso de que el panadero hubiera adquirido la harina al por mayor, tendría que añadir a la tasa 3 dineros por cada 240 de precio, es decir un $1,25 \%$, y por lo tanto los porcentajes sobre la harina panificada quedarían, los años que nos es posible calcularlos, en:

$\begin{array}{ll}1386 & 18,90 \% \\ 1387 & 13,75 \% \\ 1389 & 12,50 \% \\ 1392 & 16,25 \%\end{array}$

Aparte de las cargas sobre el consumo, los productores del grano tenían que abonar de entrada un $25 \%$ del total producido, entre la parroquia, los diezmos y "tasca" al señor del dominio, y mermas (salario a los segadores, yeguas para la trilla y el cribado), con lo que el recargo total sobre el consumo podía oscilar entre un 26' 25 y un $56 \%$.

Estas detracciones sobre la cosecha de granos eran calculadas sobre 40 medidas, múltiplo a la vez de 4 (posibles perceptores: parroquia, dominio, rey, iglesia diocesana) y de 10 (tasa aplicable al diezmo del grano), mediante la siguiente distribución:

\begin{tabular}{|l|l|l|}
\hline Parroquia & 1 medida & $(2,5 \%)$ \\
\hline $\begin{array}{l}\text { Batadures, baleigs, espiga- } \\
\text { dores }\end{array}$ & 3 medidas & $(7,5 \%)$ \\
\hline Diezmo & 3 medidas & $(7,5 \%)$ \\
\hline Tasca o trecena & 3 medidas & $(7,5 \%)$ \\
\hline De libre disposición & 30 medidas & $(75.00 \%)$ \\
\hline
\end{tabular}


Estos porcentajes, más o menos generales, tenían diferentes distribuciones según quien fuera el titular del dominio donde se había producido la cosecha: rey, iglesia o señorío.

B) En las parroquias foráneas, la "molige" se imponía sobre el consumo anual de pan por edades, modalidad que aparece en 1321 a razón de 12 dineros cada año para aquellos consumidores de trigo de edad inferior a diez años, 6 dineros por año los que tuvieran entre 5 y 10 y la mitad de estas tasas si se trataba de pan de "mestall" o mescladizo.

Estas tasas sobre el alimento básico para los foráneos las duplicaron en 1328 -al mismo tiempo que en la ciudad la "molige" y el cargo sobre la panificación se reducían a un tercio- y en 1392 aparecen triplicadas en el trigo y un poco menos en el "mestall" y otros tipos de grano:

\begin{tabular}{|l|l|}
\hline Por cada persona mayor de 10 años que consumiera pan de trigo & 36 dineros por año \\
\hline Si consumía pan de “mestall”, de mijo, de “acce” u otros granos & 27 dineros por año \\
\hline Si consumía pan de cebada & 21 dineros por año \\
\hline Por cada persona entre 5 y 10 años que consumiera pan de trigo & 18 dineros por año \\
\hline Si consumía pan de "mestall” o de los demás tipos de granos & $\begin{array}{l}13,5 \text { dineros por } \\
\text { año }\end{array}$ \\
\hline Si consumía pan de cebada & 10 dineros por año \\
\hline
\end{tabular}

\subsection{Tejidos}

El "tall dels draps" no sufrió apenas ninguna alteración en todo el siglo. Había aparecido en 1328, a razón de 12 dineros por libra (un 5\%) sobre el precio de venta o de importación de cualquier tipo de telas que fueran utilizadas para confeccionar vestidos o forros, y esta tasa la mantuvieron cuando crearon el cargo que llamarán "del sagell" o "de la bolla" para toda la corona de Aragón y para todos los habitantes -incluidos "los moros"- para la guerra contra Castilla (que amenazaba ya Zaragoza), y se convirtió en una carga permanente de hecho para el futuro. En 1390 se pagaban 15 dineros por libra $(6,25 \%)$ que cargaban al vendedor en el momento de "sagellar" la tela y que éste lo repercutiría sobre el comprador.

\subsection{Vino y vinagre}

La reventa de vino la gravaban con 8 dineros por libra $(3,33 \%)$ en 1309 , pero en 1328 la venta de vino al por menor, al por mayor para el consumo familiar, la venta de viñas o cosechas -aunque lo fuera a exentos o 
privilegiados-, la importación y la compra de vino y vinagre para vender al por menor y la venta de vino a foráneos dentro de la ciudad las cargaron en 20 dineros por libra (un 8 ' $33 \%$ )

En las postrimerías del siglo la venta de vino y vinagre, si era de la propia cosecha, suponía 1 dinero para el vendedor y 2 para el comprador, pero ya llevaba en su origen 1/6 (16 '66\%) sobre el precio en concepto de "size"-que no conviene confundir con la "sisa", aunque las les grafías son con frecuencia confusas-, tanto sobre lo que procedía de la vendimia como en lo que se vendiera en alguna parroquia "de fuera" de la ciudad, o lo que alguien introdujera dentro de la isla o dentro de la ciudad -tal vez incluido el de las viñas que pudieran circundarla, por mucho que estuvieran dentro de su término-, con todo lo que la carga total se situaba en el $18 \%$. La ciudad contabilizaba casi un tercio del vino que cotizaba diezmo en la isla ${ }^{99}$, pero muy probablemente se tratara del que pasaba por sus puertas, donde cotizaba el derecho de entrada, y no sólo del producido en su contorno.

\subsection{Las carnes}

En cuanto a la "ayuda" de las carnes que se cargaba sobre el precio al consumidor, la información que nos da el códice 29 del Archivo del Reino de Mallorca incluye precios de tasa, referidos al año 1390, lo que nos permitirá un cálculo más ajustado de su incidencia real, aunque haremos omisión de la relación de los precios de las distintas vísceras de cada animal que nos proporciona el registro.

El impuesto, que aparece por primera vez en 1309, lo habían incrementado un 50\% en 1314 y lo duplicaron entre 1321 y 1328. En 1390 había sufrido un incremento en cerca de la mitad, por lo que, con respecto a 1309, habría resultado triplicado en la mayoría de los tipos de carne:

\begin{tabular}{|l|l|l|l|}
\hline Tipo de carne & $\begin{array}{l}\text { Precio, incluida la } \\
\text { “ayuda" }\end{array}$ & $\begin{array}{l}\text { Importe de la } \\
\text { “ayuda" }\end{array}$ & $\begin{array}{l}\text { \% recargado por } \\
\text { libra de peso }\end{array}$ \\
\hline Cerdas no castradas & 7 dineros & 3 dineros & 42,85 \\
\hline Cabra u oveja & 8 dineros & 3 dineros & 37,5 \\
\hline Buey o vaca & 11 dineros & 4 dineros & 36,36 \\
\hline $\begin{array}{l}\text { Ternero/a no de } \\
\text { leche }\end{array}$ & 14 dineros & 5 dineros & 35,7 \\
\hline Ternero/a de leche & 18 dineros & 6 dineros & 33,33 \\
\hline
\end{tabular}
38.

${ }^{99}$ J.F. LÓPEZ BONET, El diezmo en el reino de Mallorca tesis doctoral inédita, op. cit. cuadro 


\begin{tabular}{|l|l|l|l|}
\hline $\begin{array}{l}\text { Carne fresca de } \\
\text { cerdo o cerda cas- } \\
\text { trados }\end{array}$ & 12 dineros & 4 dineros & 33,44 \\
\hline $\begin{array}{l}\text { Macho cabrío cas- } \\
\text { trado }\end{array}$ & 11 dineros & 3 dineros & 27,27 \\
\hline Cordero o cordera & 16 dineros & 4 dineros & 25 \\
\hline $\begin{array}{l}\text { Carnes saladas de } \\
\text { cerdo o de cerda }\end{array}$ & 22 dineros & 4 dineros & 18,18 \\
\hline Cabrito o cabrita & 24 dineros & 4 dineros & 16,66 \\
\hline
\end{tabular}

\subsection{Carga general}

En cuando a los demás productos cargados, el derecho solía ser de 2 dineros por libra a cargo del vendedor y 2 más a cargo del comprador por cada transacción y fuera cuál fuera la cantidad, es decir, un 1'66\% en total.

Este tipo -que se duplicó transitoriamente en 1335, lo que significa que existía desde antes de aquella fecha- es prácticamente general y afecta a multitud de productos, desde los quesos, legumbres y ganado hasta la madera para construir barcos. Se aplicaba tanto en el caso de que la transacción se hiciera en dinero como si se hacía en especias o por intercambio. Constituye, a pesar de su aparente ligereza, un canon acumulativo que carga el producto numerosas veces desde el instante que se pone en el mercado, empezando por la materia prima y siguiendo con todas las transformaciones y las mercancías que intervienen en cada uno de todos los intercambios que pueda experimentar.

A menudo no distingue la venta al por mayor de la venta a la menuda $\mathrm{y}$ grava por igual al productor $\mathrm{y}$ al comerciante, al revendedor y al detallista. Lo aplicaban prácticamente siempre, al menos sobre alguno de los componentes de los procesos de transformación o de conserva, incluyendo los recipientes (botas, sacas, etc.), en un alud que acaba precipitándose sobre el consumidor último, aunque la compra al por menor para el consumo individual o familiar (propri i de sa conpanya) solía estar exento o sometido a un canon más reducido de un dinero por libra.

El productor directo, sin embargo, abonaba sólo un dinero por libra en cueros adobados, en fruta seca, en seda, lana y queso, vino y vinagres (sólo en la ciudad) También abonaban sólo un dinero por libra los vendedores de un censal que cambiara de contrayentes y las cosechas que se vendieran en dinero.

Solía estar exento el consumidor en aquello que se vendiera en remate público, en "filases i baragans", en trigo del país (impuesto diferente del de la "molige" y aplicado sobre la venta de trigo o harina que no se destinara a la venta de pan o de bizcocho y que fuera, por lo tanto, para la exportación, 
usos culinarios, engrudos, etc.), en ganado de labor para el propio uso, lana, "anyins" (pieles de cabrito o cordero) y quesos, lino, estopa y hierro, y pagaban sólo un dinero en piedra, cal, botas de vino, leña y carbón.

Estaban exentos también, por estar cargados por otras imposiciones, las "gumenes" (cordajes), velas y jarcias de barcos y también el trigo vendido al por menor, el ganado que se vendiera al corte con vistas al consumo de carne -que pagaría la "sisa" el consumidor-, el vino y el vinagre adquiridos en la ciudad, los utensilios agrícolas, las cerraduras y los herrajes de las viviendas y algunos tipos de pieles vendidas al por menor.

Sólo aparecen como exentos de estas cargas los eclesiásticos, para su consumo propio -puesto que no pueden comerciar-, y los extranjeros que habían sido eximidos expresamente por algún convenio internacional. En todos los otros casos afectaban a cualquiera, privilegiado o no, que negociara en productos o subsistencias o que los adquiriera tanto para revender, como, en algunos casos, incluso para su consumo o el de su familia.

\section{LA PRESIÓN FISCAL}

El incremento de la presión fiscal, es decir, de la participación del sector público en el coste del consumo privado, experimentó en la segunda parte del siglo un incremento de las tasas de las imposiciones que, como acabamos de ver, habría sido de un $50 \%$ por término medio en pan y en trigo, de un $100 \%$ en el vino y de un $200 \%$ en las carnes, mientras que se mantenía prácticamente -a causa de la decadencia de los obradores- el recargo sobre los tejidos. Esta tendencia sin tregua se ejerce en medio de la oposición de dos tendencias opuestas:

-el aumento de las necesidades y de la deuda del sector público a causa de la necesidad de los jurados de obtener cada vez mayores cantidades para los subsidios al monarca y los suministros de la isla, que les llevaba a acumular los empeños de las finanzas públicas unos sobre los otros;

-un descenso importante de la producción agrícola (principalmente en grano) a valores próximos a un 50\%, según nos lo testimonia la recaudación del diezmo ${ }^{100}$, acompañada en el último tercio del siglo por diversas catástrofes climáticas, en una economía todavía bastante cerrada, sin recursos naturales, que no produce casi excedentes y que a menudo dependía de forma permanente para subsistir de la importación de granos y de vino.

Todo eso se aunaría en una mayor presión impositiva sobre la parte foránea que, aunque reúne un poco más de la mitad de la población de la isla, había experimentado desde 1329 un descenso de cerca de un $15 \%$ ("el dia de vuy... no es axi copiosa de poble com solia" afirma el preámbulo de una pragmática de 1382$)^{101}$, a la vez que la ciudad había experimentado una

\footnotetext{
${ }^{100}$ ID., La riqueza de Mallorca op. cit. cuadros 9, 10 y 11.

${ }^{101}$ Álvaro SANTAMARíA, Mallorca en el siglo XV, op. cit., p. 169.
} 
reducción de sólo un 8'5\%, probablemente por haber sido receptora de una migración interior provocada por las pestes y las epidemias.

El beneficio que las imposiciones sobre la mercadería -decaída desde 1335- y los tejidos -los obradores y el comercio de telas habían desaparecido prácticamente antes de 1386-, después de la necesaria ocupación de capitales en la misma actividad mercantil y en sus activos fijos, serian perpetuamente absorbidos por la deuda pública, que seguía un crecimiento acelerado.

Los beneficios que aún así pudiera generar la mercadería, invertidos en adquisición de rango y de propiedades raíces en proceso de rendimiento decreciente, lo único que harían, en cuanto a la población productiva, sería cargar todavía más las posesiones inmuebles con nuevas cargas (censos reservativos y consignativos) en cada transmisión del dominio útil. Por decirlo en otras palabras, cuando el propietario o poseedor de una finca rural cedida en explotación a un tercero invierte en renta pública, si se da el caso de que bajan las pensiones que ésta le hace, tendrá que aumentar la presión sobre sus censalistas dependientes, que pueden optar por transmitir la tenencia de la posesión a un tercero -y migrar de explotador a rentista-, mediante la imposición de un nuevo censal que se acumula sobre el nuevo explotador.

No puede sorprender, por lo tanto, que "molige", vino, carne y tejidos fueran los primeros impuestos que abolió el gobernador el 14 de octubre de 1391, ante el alzamiento armado de los foráneos y menestrales, y los primeros que se volvieron a imponer un año más tarde.

\subsection{La contribución global de la isla}

Por lo que sabemos hasta ahora, la media de lo acordado por la isla en concepto de subsidios llegó a 40.358 libras entre 1349 y 1356 y a 55.855 entre 1360 y 1385 , bastante más de lo que había indicado, repetido y transmitido sin variantes la historiografía clásica. Si consideramos que la Procuración Real recaudaba por el total de ingresos corrientes sólo entre 10.000 y 20.000 libras al año (que incluyen entre 6.000 y 8.000 libras por concepto de la mitad de los diezmos sobre todas las posesiones de la isla, incluso las eclesiásticas), podremos tal vez obtener un atisbo comparativo del déficit imponente que se tenía que ir acumulando, si atendemos a que aquel departamento era el administrador de la porción del rey, que comprendía cerca de un $70 \%$ de las posesiones insulares ${ }^{102}$

\section{LOS MOMENTOS CONFLICTIVOS}

La conflictividad anti-impositiva y la oposición fiscal por parte de la población contribuyente de la isla aparece, a lo largo del siglo XIV, neutralizada por la situación política, en estado permanente de tener que hacer

\footnotetext{
${ }^{102}$ Josep Francesc LóPEZ BonET, Comunidad y corona op. cit. pp. 128-129 son tabuladas todas las contribuciones documentadas o que nos son conocidas.
} 
aportaciones a las empresas de la corona, con el inconsciente colectivo sometido a la presencia imperativa del principio monárquico, por definición divino, intangible, inviolable e inmune. La oposición popular (menestrales y habitantes de las villas) a los impuestos no se detecta en la documentación de forma intensa antes de 1391. La evasión fiscal, la negociación fuera del mercado, la ocultación, el amiguismo y el fraude, sin duda, fueron un buen amortiguador del descontento en los momentos de presión excesiva, junto con la conciencia solidaria en situaciones de contribución bélica al monarca y de peligro que fuera considerado inminente para la isla.

La tensión anti-impositiva, por lo tanto, se nos revela, en principio, en otros frentes y por otros métodos:

a) en los continuados contenciosos ciudad-villas, a causa de la desigual carga impositiva;

b) en las tensiones con los foráneos por el control político del Consejo y para nivelar su desigual peso representativo en su seno y también ante la prepotencia de los jurados ciudadanos;

c) en la resistencia a contribuir de todos aquellos que pueden alegar alguna exención y en el permanente estado de debate entre los exentos y otros pobladores enfrente de los jurados como representantes del común;

d) en la oposición de los jurados -a menudo por vía de negociacióna los subsidios bélicos, en todas las ocasiones que se les presentan, en la segunda mitad del siglo.

Las noticias que poseemos de actitudes sociales de oposición no llegan a los acontecimientos cruentos o a revueltas generalizadas que pudieran dejar un escandalizado rastro en las crónicas o en los documentos, pero sí podemos espigar una soterrada conciencia de resistencia en constante conflagración, que nos tendría que orientar a bajar la mirada de las coronas a las abarcas:

1) La reposición de Jaume II en el trono de la isla ${ }^{103}$ conllevó una extensa amnistía para aquellos crímenes, culpas y delitos cometidos por el pueblo y los habitantes de la ciudad y la isla contra el rey y sus partidarios, en el momento en que entregaron Mallorca sin resistencia en Alfonso el Liberal; la amnistía se acompañó de la imposición de una "sisa" por nueve años (la primera que conocemos), que ligaría sin solución de continuidad con la imposición de las "ayudas vecinales" que se cargaron desde 1309 por anualidades sobre diversos artículos. Las reclamaciones que presentaron los delegados de las villas distintas de la ciudad ante del sucesor de aquel rey, Sanxo, en 1315 mencionaban aquella "size" y el tercio que debía retener la isla para gastos comunes. Si se tiene que interpretar la sentencia arbitral del rey Sanxo, como se ha hecho a menudo, como el primer indicio de una tensión entre las villas y la ciudad, ésta tendría que retroceder, por lo tanto, al momento de la imposición de la "sisa" en los inicios del siglo y a la reincorporación de Jaume II en el trono de la isla.

\footnotetext{
${ }^{103}$ ARM Pergamins Jaime II $n^{0} 10$ de 21-1-1300.
} 
2) $\mathrm{Mut}^{104}$ citaba una nueva concordia establecida entre el monarca Sanxo y los campesinos en 1322, que resolvió algunos "lites et controuersias" entre los síndicos de ambas universidades, cuando se estaba recaudando otra colecta sobre un espectro amplio de artículos y de transacciones que habían impuesto por seis años en mayo de 1321. Por mucho que la época ha sido considerada, en general, de agitaciones y movimientos de revuelta, como las de Flandes marítimo que estudió Pirenne para el periodo $1320-1328^{105}$, no tenemos más noticias de este nuevo enfrentamiento, y tampoco estamos autorizados para atribuirlo a ciencia cierta a causas impositivas, pero mediante el cálculo de las pensiones que concede la Procuración Real por individuo, se puede detectar que entre 1319 y 1321 se triplicó el número de acogidos a siete conventos de la ciudad, que en 1322 descendió de nuevo hasta un contingente un poco superior al de 1319 (con una diferencia en más sólo de un 31\%) y que, en el mismo periodo, el número de los acogidos a cuatro hospitales de la ciudad también se triplicó y volvió a descender en 1322 hasta llegar a sólo el $138 \%$ respeto al inicio del periodo ${ }^{106}$ Estas oscilaciones tan marcadas en el número de personas acogidas o refugiadas en establecimientos que les concedían inmunidad, en el espacio de sólo dos años, podría tener algún sentido de pánico social o de divisiones que pueden producir revanchas cruentas que sólo se pueden rehuir acogiéndose al cobijo de aquellos refugios; pero todo lo que pueden hacer, por ahora, es plantearnos la pregunta y espolear la investigación.

3) En septiembre de 1324, cuándo murió el rey Sanxo sin hijos legítimos, se produjeron verdaderas conmociones en la zona transpirenaica del reino, en relación a la sucesión del monarca ${ }^{107}$, con la intervención de agentes catalanes e incluso la ocupación del Rossellón por tropas catalanas, que llegaron hasta Perpiñán. Sin duda estas agitaciones tuvieron su resonancia popular en la isla, que quedó sin gobierno legítimo y bajo la administración aislada de los jurados. Se constituyó una representación de cariz popular que promovió diversos contactos hasta que el 24 de septiembre de 1325 se efectuaron Cortes en Lérida, a requerimiento de Jaume d'Aragó, a las que asistieron unos delegados mallorquines y en las que aquel monarca vino a bien, mediante compromisos matrimoniales, en aceptar la lugartenencia del tío del sucesor Jaume III -quien no tenía más que diez años- el canónigo de Elna el Infante Felip, que estaría acompañado por un Consejo de tutela y curatela, hasta tanto el sobrino del difunto Sanxo alcanzara la edad suficiente.

\footnotetext{
${ }^{104}$ Vicente Mut; Juan DAMETO, Gerónimo ALEMANY, Historia general del reino de Mallorca, III, en edición corregida, anotada y prologada por Miguel MORAGUES; Joaquím M ${ }^{\mathrm{a}}$ BOVER, ed. Imprenta Nacional a cargo de D. Juan Guasp i Pascual, Palma de Mallorca, 1840. ARM Códice XIV "Sindicato de Fuera", f. 7 v, y códice XV f. 10, sentencia arbitral de 2 de julio de 1322.

${ }^{105}$ Henry PIRENNE, Le soulèvement de la Flandre maritime 1323-1328, Bruxelles, 1900.

${ }^{106} \mathrm{Josep}$ Francesc LÓPEZ BONET, El diezmo en Mallorca, op. cit., III, apéndice estadístico, cuadros 264 y 265 .

${ }^{107}$ Álvaro SANTAMARÍA, Tensión Corona de Aragón-Corona de Mallorca. La sucesión de Sancho de Mallorca (1318-1326), Madrid, 1982; también en el capítulo 6 de El reino de Mallorca (1276-1343), en el tomo IV de la Historia General de España y América, ed. Rialp, Madrid 1984.
} 
Estanislau de Kostka Aguiló publicó ${ }^{108}$ una colección de documentos de estos momentos que hablan de pasadas siembras de inquietudes, de turbaciones y de disensiones a consecuencia de las cuales tuvieron que ser remitidos a la isla los reformadores Guillamó de Pau y Otón de Caucalis. Se puede tratar de pura retórica para justificar medidas de enderezamiento estrictas, pero lo cierto es que ante de los reformadores se presentó de inmediato (21 de noviembre de 1327) una comisión de los foráneos solicitando -y obteniendo- que no se impusiera en el futuro ninguna "ayuda, sisa, colecta o nueva imposición" en las villas hasta tanto los recaudadores de las anteriores no hubieran presentado cuentas claras y exactas. Quizás se trata de una petición rutinaria siempre que cambia el dominio, pero también nos puede desvelar una situación continuada de enfrentamiento basado en el conflicto fiscal y en las acusaciones de corrupción en el seno de la representación cameral isleña, que se refleja en la oposición ciudad-villas.

4) La tensión más evidente reflejada en los documentos se refiere al odio creciente contra las negativas de los privilegiados y sus reiterados intentos de ahorrarse cualquier contribución bajo cualquier pretexto, más o menos fundado, es a decir: el odio a su absoluta falta de solidaridad. El 15 de julio de 1364, mientras se desarrolla la segunda parte de les Cortes en Monzón y Pere IV estaba en la huerta de Burriana ocupado en plena guerra y persiguiendo a las tropas de Pedro de Castilla que asediaban Valencia, al mismo tiempo que se está concentrando una armada en Mallorca para ir en su ayuda con una importante aportación de la propia isla ( 23 naves y muchas galeras armadas, según Binimelis), el rey recibía una comisión de los caballeros militares, generosos y privilegiados de la isla, a resultas de la cual mandó emitir un dictamen en que se menciona el enfrentamiento no entre privilegiados y jurados (como seria de esperar), antes bien entre los "cives et vicinos" de la ciudad y el reino, y se extiende en la relación de los perjuicios que pueden causar los odios y rencores, mucho más onerosos que las propias contribuciones en litigio. Dentro de la misma ciudad, pues, habría habido también frentes opuestos que estorbaban la vida pública y que mantenían un estado de conflicto y de enfrentamiento que en la época, sin ningún cariz político participativo, no se podía expresar de otra manera que con gestos y actitudes de cierta violencia. Cateura detectó alrededor de 1361 "constantes alusiones a violencias en las villas entre vecinos y concejales de las villas, entre individuos y agentes ejecutivos enviados desde la capital de la isla para ejecutar bienes o agentes de las mismas villas", violencias a las que también podría haberse referido el dictamen real ${ }^{109}$.

5) No seria hasta que la representación foránea empezara a alcanzar una fuerza y una presencia vital y activa en el seno del Consejo general -de que nos daba muestras en 1373 cuando hizo causa común con los privilegiados

\footnotetext{
${ }^{108}$ Estanislau de Kostka AGUILÓ, en "BSAL", XI (abril-mayo 2005).

${ }^{109}$ BINIMELIS, Historia de Mallorca y de otras islas adyacentes (vid. referencia en la nota 7) p. 359, aunque erróneamente dice 1354. Vid. también CATEURA p. 132 y ARM Códice Sant Pere, f. 136. CATEURA Sociedad y sistema op. cit. p. 161 y nota 311.
} 
contra la ciudad a favor de un subsidio solicitado por el monarca ${ }^{110}$ - que los foráneos se verán en libertad para ejercer todo tipo de presión, hasta llegar a la violencia espontánea en 1391 y a un estado permanente de revuelta (atribuido en los textos a la depauperación de la parte foránea) que llevará a

${ }^{110}$ En la primavera de 1373 los genoveses habían preparado ya una armada de 40 galeras para ir el próximo mes de junio a socorrer a Mariano, el rebelde juez de Arborea, hecho que de inmediato los puso en conflicto con el rey de Aragón. Enrique de Castilla se había concertado ya con el rey de Portugal y amenazaba definitivamente Aragón y Valencia. El mes de mayo, el monarca de Aragón se dirigía en un tono verdaderamente suplicante a la Universidad de Mallorca solicitando que recaudaran de antemano el impuesto del "morabatí", puesto que necesitaba dinero para la defensa de Molina, que estaba amenazada por Enrique, sin alcanzar a conmover al Consejo de la isla, que se aferraba obstinadamente a sus privilegios e insistía todo el tiempo que el "morabatí" sólo lo recaudarían cuando correspondiera: cada siete años. El día 2 de junio compareció el reformador Abella ante el Consejo para soliçitar en nombre del rey el "morabatí" y para proponer que las 38 imposiciones que había en la isla se redujeran a las tres esenciales sobre molienda, carnes y vino, alegando que “... io em pensat que... pagans encara menys que vuy no paguen, montauen aytant e mes que vuyl no s' ha de totes". tambien proponía la construcción de un nuevo puente en el muelle, que constituía, según dijo "vna gran nobleza de esta ciudad". Los jurados, a su vez, tenían uno alud de protestas que hacerle a Abella, sobre todo por haber mandado sustraer a la jurisdicción ordinaria algunos delincuentes y haberles hecho aplicar tormento, contra todos los privilegios y usos de la isla; tampoco veían justificado que los reformadores recibieran una tasa de 4 sueldos por libra (un $20 \%$ ) del importe de las "composiciones" judiciales en que participaban, un importe que les parecía desorbitado; además, se sentían amenazados por la exigencia de que el Consejo demandara oficialmente a los recolectores o "llevadors" de las imposiciones, con los clavarios o jurados responsables, por un desfalco de 6.100 libras de las que no aparecían ni las cuentas ni los justificantes. El Consejo se mantuvo inmutable en su negativa de recaudar el "morabatí" y. el dia después acordó enviạr emisarios al monarca para protestar contra las infracciones a los privilegios y franquicias de la isla que, según ellos, cometían los reformadores. El 2 de julio se reunió de nuevo el Consejo y se reafirmo en su decisión de no recaudar el "morabati" hasta 1378, a la vez que aprobaban una nueva imposición sobre las naves que entraran o salieran de la isla "continuadamente", que sería aplicado a las obras del puente del muelle, y que se añadiría a los ya existentes sobre la compra y la venta de mercancías; negaban que el plan de reducción del número de imposiciones fuera factible, ya que de momento estaban repartidas sobre todos, tanto naturales como extranjeros o cautivos o cautivas y que, si se reducían a solo tres, perderían su carácter general y gravarian con demasiado peso y exclusivamente sobre ciertas actividades y personas.

Mientras tanto, el monarca había solicitado -con éxito escaso- una nueva ayuda para la causa de Cerdeña, en un escrito de 15 de julio que el gobernador Olfo había presentado ante el Consejo el 27 de septiembre; en aquella comunicación les informaba de que Cataluña había concedido ya una ayuda por aquel motivo y que esperaba que Mallorca actuara en consecuencia. El 6 de octubre, en una nueva reunión del Consejo, la isla se excusó de contribuir, dada la situación muy grave de hambre y necesidad que sufría, y sus representantes se oponían también a la propuesta de prolongar algunas imposiciones, puesto que las mismas "ordenanzas" que les había presentado Abella lo prohibían. El gobernador Olfo no renunció y mandó reunir de nuevo el Gran y General Consejo los días 7, 16 (domingo) y 18, pero sin ningún resultado. El día 12 de octubre el rey había de solicitar de los jurados que cambiaran el acuerdo que le habían participado, diciendo que no les valía la argumentación evasiva sobre la base de las malas añadas y la multitud de subsidios que ya habían entregado por el mismo motivo.

Hacia estas fechas, en el seno del Consejo se empezaban a dibujar dos partidos opuestos: en la reunión de 18 de octubre, en la que decidieron remitir los dos delegados solicitados por el rey - pero solo para escuchar y tratar, sin ninguna facultad de decidir ni de suscribir cualquier compromiso- algunos representantes de los caballeros ya se adelantaban a proponer una contribución de 4 o 5 mil florines; pero la verdadera sorpresa la dieron los representantes de la parte foránea que, por boca de Jacme de Tordera, se opusieron a la "missatgeria" expresando que la mayoría de ellos estaban convencidos de que debían contribuir a lo que había solicitado el rey, en proporción a lo que le había concedido ya Cataluña. La propuesta alborotó de tal manera la reunión que algunos llegaron a proponer que los representantes de las villas foráneas fueran expulsados de la sala.

Por lo que sabemos por otras fuentes, el Consejo vivía en aquellos momentos ciertas tensiones internas, a causa de los dos bandos extremados que intentaban hacerse con el control de las elecciones anuales, que discutían en torno a las diversas maneras de constituir y componer la cámara: el sistema "de franqueza", otorgado por Jaume I en junio de 1249, o el de insaculación, que habían probado en 1351 y lo habían dejado de lado en 1359 . El último partido, que además propugnaba la reducción del número de consejeros de los 250 que había fijado la "franqueza" a sólo 100 por la ciudad y 39 de las parroquias de fuera, terminó el año victorioso, mediante una cédula real dada el 15 de diciembre de 1373 , y no es descabellado identificar esta concesión con el bando que procuraba -quizás en virtud de algún compromiso secreto con el monarca- obtener para el rey el subsidio de los 10.000 florines que aquel solicitaba. 
fuertes enfrentamientos en 1418 y en 1435 y a verdaderas guerras civiles en 1450 y en 1520

6) En 1387, recién acabado de subir al poder, Joan I ordenó empeñar todas las temporalidades del obispo y del capítulo de la catedral de Mallorca -excepto diezmos y primicias- "por ciertas causas justas e razonables", mandó cabrevar las posesiones isleñas, inició los tratos para las paces con Cerdeña -en los que intervienen, entre otras ciudades, unos procuradores de Mallorcacon el fin de detener una guerra obsesiva de su padre que era del todo impopular e insostenible, y reestructuró el Consejo de la isla al que aumentó el número de consejeros hasta los $124^{111}$ Tres parámetros se ofrecen en estas disposiciones: la provocación a los eclesiásticos, que quizás llegan a exaltar la conciencia popular desde su magisterio absoluto e inapelable; la odiada cabrevación (exigencia de aportar documentalmente los títulos que acreditaran el derecho de posesión o tenencia, por inmemorial que fuera); y la lucha de partidos por el control del Consejo general de la isla.

Joan I mandó convocar de nuevo las Cortes generales de sus reinos -excepto Córcega y Cerdeña- en Monzón, con la intención de continuar las que había interrumpido la muerte de su padre. La continuación de las Cortes no fue menos conflictiva que su primera parte y en ellas comparecen precisamente como más exigentes los procuradores de Mallorca, que participaban con los de las villas reales de Cataluña.

Todo el año 1389 se pasó en desacuerdos, hasta que mes de noviembre tuvieron que ser suspendidas las Cortes, hasta dos meses después de que se desvaneciera el estado de peligro en que de nuevo habían puesto al reino las dos tradicionales amenazas: movimientos de rebelión en Cerdeña -con sospechas de agresión por parte de Génova- y las tropas francesas que, dirigidas por el conde de Armañac, se habían instalado con propósito hostil en la frontera pirenaica.

El 9 de septiembre de 1390, desde Barcelona, había emitido el nuevo rey una comunicación dirigida a los jurados y prohombres de Mallorca en relación a los capítulos del acuerdo que había alcanzado con el emisario de aquellos, el impopular y corrupto Antoni Castell, relativos a la cabrevación y otras concesiones, y en contrapartida reclamaba 8.500 florines (6.375 libras de Mallorca), que tendrían que liquidar al tesorero real o al mercader de Barcelona Berenguer de Cortilles y para los que les autorizaba a emitir censales muertos y violarios, mediante carta de gracia (es decir, a título de préstamo, transmisible y rescatable). En correspondencia, los jurados estaban autorizados, para poder cubrir la emisión y todos sus gastos, a imponer, instituir y ordenar nuevas imposiciones, ayudas o generalidades en la isla sobre cualesquiera víveres, cosas y mercancías que llegaran o que se sacaran del reino o que se vendieran, compraran o contrataran de cualquier forma. El día 12 del mismo mes el rey concedía una ampliación de la deuda en 3.000

${ }^{111} 114$. En septiembre, por la Pragmática de Barcelona, el número de Consellers pasó de 90 a 111; el 13 de diciembre, por la Pragmática de Vilafranca dels Panadés, aumentaron un $50 \%$ el número de los foráneos y redujeron en un $10 \%$ el de ciudadanos. 
florines más (2.250 libras) con el fin de recaudar la cantidad que tendrían que prestar al mencionado Cortilles para la acuñación de moneda.

Antoni Castell, a cambio de un préstamo personal al monarca, había obtenido el derecho de recaudar por su cuenta el impuesto del pescado de la Albufera y lo ejercía cínica y despóticamente, llegando a adjudicar las subastas por rifa, lo que se antojaba una afrenta a los posibles compradores y comerciantes, y sería pronto el blanco de las iras populares, de manera que su inmediata deposición sería una de las reivindicaciones en la revuelta de los foráneos y menestrales del año inmediato. Pero, además, se nos ofrece un cuarto rasgo que nos acerca a otro de los motivos que encenderían el alzamiento de 1391: el incremento de la carga fiscal sobre los productos de consumo que, sin duda, había llegado a ser ya imposible de sostener sin que -todo lo indica- hubiera disminuido el nivel de corrupción y de impunidad por parte de los administradores del común.

Las múltiples tensiones generadas, junto con una oscura sugestión colectiva anti-judía que llevó al asalto en la "judería" de Mallorca -en extraño mimetismo con una corriente que entre junio y agosto de 1391recorre todo el levante, desde Sevilla a Perpiñán, y que llegará incluso a Burgos, Logroño, Palencia y León- explotó en 1391 en un conflicto violento de claras motivaciones anti-impositivas.

No hay noticias anteriores de ningún movimiento violento anti-judío de tal amplitud ni siquiera en 1348, en los peores momentos de la Peste Negra. En 1305 un grupo, capitaneado por un eclesiástico -un tal Galceránhabía embestido la "judería" y causado algunos daños y alarma ${ }^{112}$; algunas disposiciones posteriores de cariz económico de singular dureza indican una creciente hostilidad o presión sobre la aljama; en $1376^{113}$ los judíos de Porreres se quejaban de continuos maltratos y vejaciones por parte de algunos habitantes y de cuadrillas de pobladores. Aún así, la aparición del asalto de 1391 a la judería ha sorprendido por su violencia y su amplitud, tal vez porque el atractivo tema de los judíos había ocultado el verdadero origen de la revuelta. Los capítulos aportados por los foráneos ${ }^{114}$ nos demuestran que el asalto a la Judería no es más que un episodio dentro de un amplio alzamiento popular que tiene una clara raíz anti-impositiva y que, iniciado la madrugada del 2 de agosto con el cerco de la ciudad por un ejército de campesinos, reforzado desde el interior de las murallas por el asalto a la judería que duró desde las 3 a las 10, se prolongó por más de dos meses con el asedio a la ciudad, con una segunda oleada de campesinos armados de hasta 4000 hombres el día 27 de agosto y con una tercera en que llegarían a ser entre 6 y 7 mil el 2 de octubre, que llegaron a asediar el Castillo de Bellver donde se habían refugiado el Jurat en Cap y diez de sus compañeros y parientes. Bajo la presión armada de los foráneos, el 14 de agosto se había suspendido la

\footnotetext{
${ }^{112}$ Álvaro SANTAMARÍA, Sobre el antisemitismo, op. cit., p. 116.

113 "BSAL", VII (junio 1897), p. 96.

${ }^{114} \mathrm{Vid}$. mi comunicación La revuelta op. cit.
} 
recaudación de impuestos y el 30 de septiembre el Consejo de la isla los había revocado.

El resultado de estos acontecimientos sería un castigo económico colectivo de una extremada dureza. La necesaria recaudación de la cantidad impuesta como pena a la isla legitimaría para lo sucesivo cualquier capacidad de corrupción y de soborno de los jurados, lo que llevaría las finanzas del común a la clara quiebra una década escasa después de que el orden se hubiera restaurado.

Ante los 61 capítulos presentados por los foráneos en octubre de $1391^{115}$ podemos entrever el componente social que se imbrica con el malestar económico de los insurgentes.

El primer fruto del alzamiento contra la ciudad había sido la revocación bajo la presión popular, el 30 de septiembre, de los impuestos sobre el consumo y las transacciones mercantiles. Las 61 peticiones de octubre, impuestas con el apoyo del asedio armado a la ciudad, se refieren a: -el fraude continuado en el manejo de fondos públicos y los excesivos gastos de los "consejeros" de las villas y de la ciudad;

-el impago por parte de la ciudad de cantidades que debía a las parroquias foráneas y el uso indebido de los caudales comunes para causas que eran exclusivamente en interés de la ciudad;

-los abusos en el cobro de censales -arrendamientos y títulos de deuda-y en sus remisiones, y también en su registro por escrito;

-los numerosos censales a pagar en especie (generalmente en grano), que despojaban de recursos a las villas y que, en contra de lo esperado por los censatarios, no seguían el proceso degenerativo del valor en moneda en el caso de que subieran los precios, sino que se mantenían a la par, al constituir el grano una especie de patrón económico;

-desigualdades en la administración de justicia y de policía con respecto a los foráneos, que se veían comparativamente peor tratados y mayormente agravados y recargados en gastos, desplazamientos y cargas; -los préstamos usurarios efectuados principalmente por judíos, pero también actividades consideradas como usura por los foráneos, como lo eran los recargos no autorizados en los precios en épocas de carestía y la tasación exagerada de las ventas de posesiones y de ganado con pago diferido;

-las exenciones invocadas de forma impertérrita por el clero;

-la evasión fiscal en los impuestos locales de las villas por parte de aquellos titulares de fincas rústicas que se pretendían vecinos o residentes en la ciudad;

-el trafico de la fuerza de trabajo de los cautivos que hacían los intermediarios que les tenían contratados a "talla" (por horas o por días);

-los fraudes por parte de caballeros y de otros que no cumplían la obligación, que iba anexa a la tenencia de sus fincas, de mantener los caballos armados correspondientes;

\footnotetext{
${ }^{115}$ ARM AH 419 p. 196 bis. y ss.
} 
-la falta de suministros en grano y vino, por lo que pedían que todos aquellos que sacaran aceite, lana, higos, sal y otras mercancías de la isla se comprometieran a importar la cantidad equivalente de aquellas subsistencias; públicos.

-las banderías y partidos que manipulaban a su gusto los asuntos

Son reivindicaciones antiguas -algunas, cómo hemos visto, reiteradas desde principios de siglo-, que resumen a grandes rasgos una situación generalizada de expolio, injusticia y abuso por parte de las clases privilegiadas y de los exentos, rentistas y administradores de los caudales públicos, todo lo que, junto con la presión fiscal de la que es agravación y en parte también causa, pesaba sobre la economía familiar y el consumo doméstico.

\section{APÉNDICE \\ LAS FASES DE LA EVOLUCIÓN SECULAR EN EL TRESCIENTOS EN MALLORCA}

Del estudio de las entradas de la Procuración real y de la Iglesia de Mallorca del siglo XIV, y singularmente de las que provenían de la recaudación del diezmo ${ }^{116}$, se puede extraer la visión neta de dos fases que presentaron entre ellas diferencias muy marcadas, en paralelo con la tendencia común en los demás reinos del occidente cristiano: una primera mitad del siglo de crecimiento y empuje comercial y económico contrasta con una larga tendencia de bajada a partir de la década que se cierra hacia 1348 (peste negra), en coincidencia con un general enfriamiento del continente europeo acompañado por un descenso de los rendimientos de los cultivos y de las superficies cultivables que, además, incide sobre las consecuencias de un crecimiento demográfico por encima de los umbrales tolerables.

La década de 1320 a 1330 es la de mayor volumen de recaudaciones de la "taula de de leuda" (tributo sobre el movimiento portuario de mercancías) y coincide, efectivamente, con un descenso -en una banda comprendida entre los 10 y 15 sueldos por cuartera- de los precios del trigo, seguido en paralelo por los precios de la cebada dentro de un margen de entre 4 y 7,5 sueldos por cuartera. Hasta 1347 los precios del grano se mantienen más o menos bajos, dentro de estos límites; pero alrededor de la mitad de los años cincuenta se produce el cambio de tendencia que les hará rebasar los máximos del periodo anterior por todo el resto del siglo.

En las finanzas del fisco real, la caída de la actividad comercial (hacia 1335) hace que el peso relativo de las principales fuentes, tanto en la ciudad como en la parte foránea, se desplace hacia los ingresos que le restan (los diezmos y la renta inmobiliaria), y ello empieza mucho antes de la peste negra y se corresponde con una nueva actitud recíproca de los reinos musulmanes

\footnotetext{
${ }^{116}$ Josep Francesc LóPEZ BonET, El diezmo en el reino de Mallorca op. cit. Los capítulos de la tesis relativos a parámetros económicos de la Mallorca del siglo XIV, después de diversas reelaboraciones, fueron publicados, ampliamente completados, en La riqueza de la isla de Mallorca. op. cit. .
} 
y cristianos ${ }^{117}$ en los momentos en que la isla tiene que conceder un don al monarca de 66.644'4 libras (más 122'65 por un "convite" y las 1.500 abonadas por Menorca) y que se duplican los impuestos sobre la compra-venta de mercancías y de artículos de consumo.

Después de 1336 se produce también el inicio del proceso de decadencia demográfica, que será ya preocupante en 1343, y que es probable que rebasara el $14 \%$ de la población de la isla, un descenso inferior en muy poco al que se producirá entre aquel último año y 1348-49. En los momentos que se extiende la peste negra, pues -si consideramos aceptables los resultados del tributo del monedaje o "morabatí" que se han utilizado como indicadores de estas tendencias demográficas- la isla había disminuido ya en casi un $26 \%$ de su población en los últimos doce años. Este descenso poblacional anterior a 1348 no es inusual en otros países occidentales, que venían experimentando reducciones parecidas desde aproximadamente 1320, y se aplica -cómo hemos dicho- sobre unos volúmenes de explosión demográfica que en ciertos sitios habían llegado a ser excesivos y que estaban poniendo las bases para que la peste de 1348 fuera una verdadera catástrofe ${ }^{118}$. Por ello, debemos aceptar que la peste no fue determinante única -ni mucho menos generalizada- de la crisis, puesto que incidió en una época que era ya de recesión y en Mallorca llegaba envuelta en los avatares políticos de la reincorporación al reino catalánaragonés.

Después de una cierta estabilidad en la década de los años 50, que da confianza a la corona aragonesa para los continuados expolios económicos que intenta ejercer sobre la isla en los momentos duros de la guerra contra Castilla, seguirán las décadas climáticamente más adversas del siglo.

Existe otra posibilidad de análisis, si vemos con espíritu crítico los datos del "morabati" y dejamos de considerarlos como un índice de los habitantes -que lo es sólo de una manera muy problemática y con un margen de error demasiado amplio- y los miramos como aquello que de hecho eran: un índice del número de "contribuyentes" y, por lo tanto, de la distribución de la riqueza fiscal en la isla.

De ser así, fuera como fuera, sus índices decrecientes mostrarían la concentración de capitales en menos manos y esto habría supuesto una polarización de los sectores de la población, con un crecimiento de los dependientes o desprovistos de patrimonio y de reservas de capital. Significaría, por lo tanto, una especie de "proletarización" de capas de la población que irían a añadirse a la oferta de trabajo asalariado, y que a la larga tendría que contribuir a un descenso de los salarios. Si tenemos en cuenta que este contingente es consumidor exclusivamente de subsistencias adquiridas en el mercado, se puede inducir que esta tendencia descendente en la retribución del

${ }^{117}$ Chạrles-Emmanuel DuFOURCQ, l'Espagne catalane et le Maghrib aux XIII ${ }^{\circ}$ et XIV ${ }^{o}$ siecles, Univerșidad de Bordeaux et Casa de Velázquez, Biblioteque de l'ècole des hautes études Hispaniques, Fasc. XXXVII, Paris, 1966; ID., Aspects Internacionaux de Majorque durant les derriers siècles du Moyen Age, separata de "M̉ayurqa", XI (junio 1974), pp. 5-52.

${ }^{118}$ Vid. Álvaro Santamaría, La Peste Negra en Mallorca, "VIII CHCA", II-1 Valencia, 1969, pp. 103.130. 
trabajo aparece en los mismos momentos que la demanda, incrementada por parte de estos empleados dependientes y no productores, podría contribuir a una subida en los precios. Estos dos vectores casi paralelos y opuestos, en una economía rígida y prácticamente de subsistencia, podrían haberla encaminado hacia un proceso "inflacionario" de crisis y la habrían hecho definitivamente no competitiva con respecto a los mercados exteriores.

La fase de concentración de capitales habría sido, pues, la de la expansión comercial del primer tercio del siglo, cuando la economía se habría aprovechado momentáneamente de un descenso de los salarios favorable al intercambio de sus productos y servicios, hasta tanto la contracción de la demanda interna pudiera hacer que se mantuvieran los precios por debajo de la tendencia alcista que la escasa mano de obra impelía en otros países.

Rebasada la mitad del siglo, la conjunción de la reducción de los ingresos por tráfico mercantil y portuario con la caída demográfica, junto con la alienación de parte de la renta inmobiliaria del erario real por parte de Pere IV -que fomentó la acumulación de bienes raíces "fiscales" en manos privadas- y con la correlativa salida de la isla de los capitales obtenidos por la transferencia, contribuirán a una mayor dependencia agraria de la economía -precisamente en los momentos en que la producción de los cultivos entra en crisis- y al traslado a la parte foránea de la presión recaudatoria, que incidirá sobre el sector más castigado por la prolongada etapa depresiva. Todo eso habría neutralizado los efectos de unas cosechas que, excepto en 1373-1375 y quizás en 1361 (en que se declaró otra peste virulenta en las zonas mediterráneas del mediodía francés y de Cataluña), no hubieran sido tan insuficientes para una población ya disminuida.

De hecho, todos los indicadores y noticias que conocemos nos indican que las décadas entre 1312 y 1340 (con un brote de peste en la ciudad en 1331 y un mal año intermedio en 1334) y las de 1350 a 1371 fueron de buenos años para los cultivos, mientras que en el resto del siglo una buena cosecha cada tres años era casi excepcional. Demográficamente, en efecto, el morabatí de 1363 nos presenta por primera vez un incremento hasta cifras próximas a las de 1343 (previas a la peste negra), después de haber experimentado importantes descensos desde principios del siglo.

En la segunda mitad del siglo se hace patente un aumento de los precios del cereal que se moverán en general dentro de una franja que tiene su punto medio por encima de los máximos del periodo anterior. Además de las oscilaciones climáticas y las adversidades debidas a irregularidades meteorológicas y de multitud de otras causas que se nos escapan, algunos de los factores que hemos visto pueden influir de manera secundaria sobre este aumento:

-un crecimiento rápido de la población después de la peste negra, quizás debido a una mayor natalidad, a un descenso de la edad de nupcialidad y a un crecimiento correlativo de los matrimonios, o también a una mayor tasa de fecundidad de la población que ha podido resistir a la peste que habría incidido primero, lógicamente, y de manera más virulenta, sobre los grupos de viejos y niños y también sobre los más desnutridos; 
-una reocupación de terrenos cultivables, en los que se aplicarían los capitales desocupados después de la caída del comercio exterior, que nos viene testimoniada por el incremento en la percepción de "censos" y rentas sobre la explotación de cultivos que se experimenta en las entradas de la Procuración Real desde la sexta década, respecto de la fase anterior en que estas entradas habían sufrido un serio recorte a más de la mitad. Esta reocupación, sin embargo, y dado el estado de la técnica en la época, podría haber producido una reducción en los rendimientos medios de la tierra cultivable, puesto que se habrían puesto en explotación tierras marginales y quizás se habrían fragmentado o sobre-explotado hasta el agotamiento las tierras más fértiles; la población, a consecuencia de la peste, tendía a expandirse hacia las zonas periféricas de la isla y la calidad del grano posiblemente se vio afectada por ello;

-una mayor presión fiscal sobre la parte foránea que, junto con el aumento de "censos" en grano (aunque existe ya una tendencia contraría poco importante a convertirlos en moneda mediante contratos de "reducciones"), podría haber retirado del mercado de bienes de consumo foráneo una parte del cereal producido, favoreciendo con ello una subida artificial de los precios;

-un aumento de la ganadería en tierras pobres dejadas en barbecho más a menudo y que sufrían rendimientos decrecientes de la producción de granos panificables, lo que impondría, por una parte, una merma en la producción de granos diezmables al 10\% (en el caso de los forrajes lo eran sólo al 9\%, o al 7'7\% si se ponían en venta al por menor) en ciertas zonas que antes habían sido de cierta importancia, como el "raiguer" en torno a Inca que no se había recuperado de la peste; por otra parte, se impondría un mayor consumo para la nutrición del ganado, que haría presión sobre los precios de algunos tipos de grano (avena, cebada, mescladizo...).

Exceptuando Santanyí, en el extremo sur de la isla, se puede dibujar una frontera virtual de suroeste a nordeste (interrumpida sólo por las zonas de Inca-Sineu-Sant Joan y Algaida-Sencelles-Binissalem, limítrofes de esta línea) por encima la que, en 1363, se había perdido población con respecto a 1329 en beneficio de la otra mitad de la isla, que en gran parte se había recuperado, además, de la peste de 1348-49.

Conjugados, pues:

-una población rejuvenecida y rápidamente recuperada;

-la explotación de nuevas tierras de bajos rendimientos hacia el sur y el levante, mediante el desplazamiento de la densidad de población hacia las zonas con más cereal, que se ven así también sobre explotadas y tal vez más fragmentadas;

-un relativo cambio de actividad económica en la parte central del "raiguer", al pie de la cordillera norte de la isla, donde quizás se concentran grandes cantidades de terreno antes productivo -por escaso que fuera- para dedicarlo a la ganadería, -que estaba exenta de pagar diezmo a la iglesia- y que hacía que resultara sobre-explotado de manera extensiva, dado que presentaba déficits importantes de población; 
-una mayor presión fiscal sobre una menor producción en términos absolutos, con rebrotes de pestilencia en 1361/62 (la "peste de los niños" quizás más grave que lo que se ha supuesto), recolecciones en descenso desde 1371 y prácticamente nulas en 1374 (el "any de sa fam"), trombas de agua el invierno de $1378-79^{119}$, sequedad en $1381^{120}$ y 1383 , y un nuevo rebrote de pestilencia en febrero ${ }^{121}$;

-un aumento de los "censos" -que se corresponde con el descenso en las transmisiones de fincas que nos muestra la curva de percepciones de laudemios al real patrimonio-.

Todo puede favorecer un descenso de la oferta de grano por habitante y por lo tanto una subida de los precios.

En cuanto al negocio mercantil, su caída fue rápida y profunda: en octubre de $1380^{122}$ unos delegados enviados al monarca aludían a que el reino estaba "... tan diminuit en la art de la mercaderia..." que existía el temor que "se.ns allunyaran los strangers...". A la caída comercial se añadía la presión económica ejercida por el monarca aragonés que se había posesionado de la isla desde 1343, acompañando a la crisis agrícola que atravesaba la segunda mitad del siglo. El mismo rey no dejaba de reconocerlo el 19 de marzo de 1385 , cuando aceptaba que no podía extraer más capitales de la isla "per los grans carrecs del temps passat e en special per les ajudes e altres messions que ha hauda de dar e fer per provisions de blat en los anys passats e present". Poco tiempo después, el 15 de febrero de 1386, cuando autorizaba medidas proteccionistas para la entrada de paños extranjeros en la isla -que según él era lo único que la podía mantener- Pere IV tendrá que resumir que "regnum predicte valde depauperatus est, et gentibus et facultatibus exhaustum, et ars mercantilis in tantum minuerit in eo quod relictus ac residens hibi populus, nisi ex lanarum et panorum obragiis, que satis comuniter et utiliter ibi fiunt, vivere non posset".

Cabe insistir en que, por lo que respecta a la producción agraria, la crisis de 1373/75 fue mucho más grave que la de 1347-48, que fue de tipo epidémico y que, por lo tanto, tuvo una mayor incidencia sobre el número de las personas que sobre las subsistencias. La crisis de 1347-48 es, pues, la más grave del siglo, en parte por ser resultado de un proceso de degeneración que se arrastra desde 1341, pero no es la más profunda en todos los sentidos: la crisis de 1373-75, de más inesperada aparición cortando una fase de alza ${ }^{123}$ y

\footnotetext{
${ }^{119}$ Josep Francesc López Bonet, Comunidad, op. cit., p. 113.

${ }^{120}$ Ibidem, p. 119.

${ }^{121}$ Cronicón, p. 75; ARM RP 3809.

${ }^{122}$ ARM Códice Cortes Generales, f. 76.

${ }^{123}$ Con notable exageración, el notario Mateo SALZET, en su noticiario, que fue editado en el "Almanaque del diario de Palma" de 1872, p. 61, evaluaba en 35.000 los muertos en la peste de enero de 1375 , correlativa a las hambres del segundo semestre de 1374 . Pero en 1348 los muertos habían sido evaluados, según Guillermo TERRASSA, en 15.000 (Cronicón, p. 61), que suponía, nos dice, un 80 por ciento de la población. Es difícil creer que aquella se hubiera más que doblado en 27 años. De acuerdo con la cifra de Terrassa, era de unas 18.750 personas en 1348. Vid. para el tẹma demográfico, la obra de Alvaro SANTAMARÍA, Análisis del morabatín, ya mencionada, y mi precisión en el apéndice de Comunidad y Corona, op. cit.
} 
debida sobre todo a las malas cosechas, es más destacada, como nos lo revela el diezmo, prácticamente sin recaudación, mientras que en 1347-48 se habían hecho algunas subastas y la Procuración Real había ingresado cantidades en impuestos bajos pero superiores, en la parte foránea, a las de 1328, que no había sido un año de muy grave reducción de los ingresos (14.020,87 libras sobre una media de 16.453 en el quinquenio 1326-1330).

Fecha de recepción del artículo: junio 2003

Fecha de aceptación y versión final: febrero 2008. 